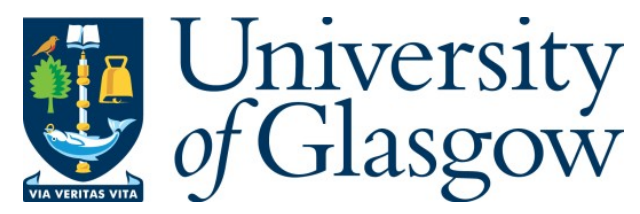

Chen, Z., Hung, W.-Y., Li, D. and Xing, L. (2017) The impact of bank merger growth on CEO compensation. Journal of Business Finance and Accounting, 44(910), pp. 1398-1442. (doi:10.1111/jbfa.12263).

There may be differences between this version and the published version. You are advised to consult the publisher's version if you wish to cite from it.

This is the peer reviewed version of the following article: Chen, Z., Hung, W.-Y., Li, D. and Xing, L. (2017) The impact of bank merger growth on CEO compensation. Journal of Business Finance and Accounting, 44(9-10), pp. 13981442, which has been published in final form at 10.1111/jbfa.12263. This article may be used for non-commercial purposes in accordance with Wiley Terms and Conditions for Self-Archiving.

http://eprints.gla.ac.uk/144168/

Deposited on: 28 July 2017

Enlighten - Research publications by members of the University of Glasgow http://eprints.gla.ac.uk 


\title{
The Impact of Bank Merger Growth on CEO Compensation
}

\author{
Zhian Chen \\ School of Banking and Finance, University of New South Wales, Australia \\ Wing-Yee Hung \\ Ernst \& Young, Sydney, Australia \\ Donghui Li* \\ Management School, Jinan University, China \\ Lu Xing \\ Business School, University of Edinburgh, United Kingdom \\ Adam Smith Business School, University of Glasgow, United Kingdom
}

\begin{abstract}
We examine the impact of bank mergers on chief executive officer (CEO) compensation during 19922014, a period characterised by significant banking consolidation. We show that CEO compensation is positively related to both merger growth and non-merger internal growth, with the former relation being higher in magnitude. While CEO pay-risk sensitivity is not significantly related to merger growth, CEO pay-performance sensitivity is negatively and significantly related to merger growth. Collectively, our results suggest that, through bank mergers, CEOs can earn higher compensation and decouple personal wealth from bank performance. Furthermore, we document a more severe agency problem in CEO compensation as a consequence of bank mergers relative to mergers in industrial firms. Finally, we find that the post-financial crisis regulatory reform of executive compensation in banks has limited effectiveness in curbing the merger-pay links.
\end{abstract}

JEL classification: G12; G15; G32

Keywords: CEO compensation, incentives, bank mergers, financial crisis

* Corresponding author: Donghui Li, Management School, Jinan University, 601 Huangpu Avenue West, Tianhe District, Guangzhou 510632, China. E-mail address: lidonghui@jnu.edu.cn.

$\dagger$ We thank Ronan Powell (the editor) and an anonymous referee for their insightful comments and suggestions. All errors are our own. 


\title{
The Impact of Bank Merger Growth on CEO Compensation
}

\begin{abstract}
We examine the impact of bank mergers on chief executive officer (CEO) compensation during 19922014, a period characterised by significant banking consolidation. We show that CEO compensation is positively related to both merger growth and non-merger internal growth, with the former relation being higher in magnitude. While CEO pay-risk sensitivity is not significantly related to merger growth, CEO pay-performance sensitivity is negatively and significantly related to merger growth. Collectively, our results suggest that, through bank mergers, CEOs can earn higher compensation and decouple personal wealth from bank performance. Furthermore, we document a more severe agency problem in CEO compensation as a consequence of bank mergers relative to mergers in industrial firms. Finally, we find that the post-financial crisis regulatory reform of executive compensation in banks has limited effectiveness in curbing the merger-pay links.
\end{abstract}

JEL classification: G12; G15; G32

Keywords: CEO compensation, incentives, bank mergers, financial crisis 


\section{INTRODUCTION}

Mergers and acquisitions (M\&As) are major, externally observable and discretionary long-term investments that provide managers with opportunities for their incentives (e.g., hubris, personal risk reduction and perquisites) to diverge from the interests of shareholders (Bliss and Rosen, 2001). These potential agency problems can also be inferred from the links between asset growth through M\&As and chief executive officer (CEO) compensation. Jensen (1986) argues that managers can grow their firms beyond the optimal size, which brings about increased managerial power and better remuneration. Seo et al. (2015) find that relatively underpaid CEOs tend to engage in M\&As to increase their pay to the level of their peers. However, theoretically and empirically, it remains unclear whether CEOs receive beneficial compensation through M\&A activity. While Bliss and Rosen (2001), Grinstein and Hribar (2004), and Harford and Li (2007) find a positive effect of M\&As on subsequent executive pay, Avery et al. (1998) find no such effect. To clarify the unsettled merger-pay relation, our paper investigates what private benefits in compensation accrue to CEOs by undertaking M\&As. CEO compensation is estimated as a function of asset growth, market value and accounting profitability, among many other factors. To study the merger effect, we distinguish asset growth through M\&As from non-merger internal growth.

To examine the links between CEO compensation and M\&A decisions, this paper focuses on the banking industry, which provides a natural laboratory on this issue. Minnick et al. (2011) argue that the role of regulatory supervision in banks can be a substitute for, or a complement of, internal corporate governance (e.g., CEO compensation), and that some specific governance issues (e.g., the relation between CEO compensation and M\&As) that are valid in industrial firms may not be valid in banks (Adams and Mehran, 2003; Barth et al., 2004). The risk-shifting problem is particularly severe in banks because of their high leverage (John et al., 2010), which complicates the agency problems, making the effective design of executive compensation contracts, as a remedy to mitigate the problems, especially important. Furthermore, according to Minnick et al. (2011), the M\&As made by banks are normally within the single financial industry and are thus not driven by industry rebalancing. The single industry study addresses the challenge of identifying industry sectors in fixed-effect regressions, as the industry 
classifications may not be detailed enough.

The banking industry in the United States is an appropriate setting for analysing the impact of M\&As on CEO compensation arrangements for at least two reasons. First, the federal deregulations of the banking industry opened up new opportunities for banks to grow via M\&As, leading to increased decision-making power of managers through controlling enlarged banks (Hope and Thomas, 2008; Jensen, 1986). The Riegle-Neal Interstate Banking and Branching Efficiency Act of 1994 removed most restrictions on interstate bank M\&As and allowed banks to open branches in multiple states. The Gramm-Leach-Bliley Financial Services Modernization Act of 1999 eliminated the barriers that forbade commercial banks to merge with insurance underwriters, securities brokerages and investment banks. Following the creation of expanded investment sets for banks, a large amount of consolidation occurred. Second, the majority of debt holders of banks (i.e., dispersed depositors), who are insured by the Federal Deposit Insurance Corporation (FDIC), lack the incentive, as well as the ability, to monitor the actions of bank managers. It is thus likely that bank CEOs employ the expanded investment options via M\&As to seek favourable compensation contracts.

The U.S. banking industry exhibits different characteristics from non-financial industries and, hence, may exhibit different patterns when we examine the links between CEO compensation and M\&As. First, the banking industry is heavily regulated, compared to non-financial industries. Becoming large is especially important for banks. M\&As, as a means to achieve rapid size expansion, benefit bank shareholders, as those banks deemed 'too big to fail' enjoy advantageous regulatory treatments, such as government bailout, to prevent extreme downside risk. It remains an empirical question whether the heavy regulation in banking can re-shape the merger-pay links documented in non-financial industries. Second, bank CEO pay is based on less equity than CEO pay in non-financial industries (Adams and Mehran, 2003); and bank CEO pay-risk sensitivity is significantly lower than that of industrial firms, despite efforts by banks since the mid-1990s to increase it (Belkhir and Chazi, 2010; DeYoung et al., 2013). The disparity in their pay structure calls for careful explanations of the differences in M\&A engagement between bank CEOs and non-financial firm CEOs. Third, corporate governance practices of banks are not identical to those of industrial firms (Adams and Mehran, 2003). It is meaningful to study whether CEO compensation, as a major internal governance mechanism, functions differently in 
linking to M\&A decisions across the two groups of firms. Fourth, compared to shareholders of industrial firms, bank shareholders are likely to take excessive risks at the expense of debt holders (John et al., 2010). One such activity is M\&As, which are economically significant and highly risky in nature. Banks are debt holders of industrial firms and have the incentives to monitor the latter using their expertise and information advantage. In contrast, bank depositors do not have the incentives to monitor bank managers, as their deposits are largely insured. Given the risk nature of M\&As and the different monitoring roles of debt holders, it is worthwhile to study whether M\&As are associated with CEO compensation differently across banks and industrial firms.

We decompose asset growth in banks into growth driven by bank mergers and internal growth unrelated to mergers. We examine the changes in CEO compensation in response to the two different means of bank growth. Several key findings emerge. First, we document a positive relation between CEO total compensation and asset growth through bank mergers. Among the components of the total compensation, merger growth significantly increases the level of equity compensation but does not significantly affect the level of cash compensation. Second, CEO compensation is positively related to non-merger internal growth. However, it adds much less to CEO compensation than does the same dollar amount of merger growth. Acquiring \$1 million of new assets through mergers increases CEO total compensation by $\$ 187.5$; by comparison, $\$ 1$ million of non-merger internal growth increases the total compensation by only $\$ 13$. Finally, while CEO pay-risk sensitivity (vega) is not significantly related to merger growth, we find that CEO pay-performance sensitivity (delta) is negatively and significantly related to merger growth, which suggests that, through M\&As, CEOs wield their increased power to decouple their equity wealth from bank performance.

We address endogeneity problems in three ways. First, we include firm-fixed effects to control for time-invariant firm heterogeneity that may drive the merger-pay relation. Second, as we find the current level of CEO compensation is associated with its past levels, we use a dynamic panel system generalised method of moments (GMM) estimator (Arellano and Bover, 1995) to mitigate reverse causality and time-invariant omitted variable bias. Third, we adopt a difference-in-differences (DiD) estimator combined with propensity score matching (PSM) to further alleviate the endogeneity concerns. The DiD estimator compares the variations in CEO compensation around M\&As between acquiring 
banks and matched non-acquiring control banks, which removes the effect of constant firm-level heterogeneity and unobserved common time trends. Matches between acquiring and non-acquiring control banks are identified by using PSM, which reduces the selection bias due to observed factors that drive bank mergers. The empirical results reaffirm our main findings.

We split the sample banks into high versus low groups based on the median dollar value of bank merger activity over the sample period. We find that CEOs of high-merger banks are paid less per dollar value of assets acquired through M\&As than CEOs of low-merger banks. The result suggests that highmerger banks discourage CEOs' excessive merger activity through compensation arrangements. In addition, we find that merger growth significantly increases CEO vega of low-merger banks but does not significantly affect the vega of high-merger banks. This indicates that low-merger banks respond to their below-median M\&A intensity by conferring more incentives on CEOs to employ risky investment opportunities.

We extend our analysis to the compensation arrangements of 'top five' executives in banks. We find that asset growth through bank mergers increases their total compensation. More specifically, it increases the level of equity component but does not affect the level of cash component, which is consistent with our findings for bank CEOs. Nonetheless, we do not find that top five executives' delta or vega shifts around bank mergers.

We compare the impact of M\&As on CEO compensation in industrial firms with that in banks. Industrial firms operate in different business and regulatory environments. Their merger impact on compensation structure as well as the incentives derived may be different. We show that mergers in industrial firms substantially increase CEO cash compensation, a result absent in bank mergers. One possible explanation is that industrial firms are regulated to a lesser extent, making the large cash payments more feasible. Although CEOs in industrial firms gain higher total and equity compensation after M\&As, their compensation increases due to mergers are smaller than those in banks. In industrial firms, both CEO delta and vega increase following M\&As, indicating that the post-merger compensation arrangements better align CEO incentives with shareholder interests and motivate CEOs to take higher risks. The results taken together highlight a less severe agency problem in CEO compensation as a consequence of industrial firm mergers compared to bank mergers. In line with this 
argument, our DiD analysis shows that, relative to matched mergers in industrial firms, bank mergers significantly increase CEO total and equity compensation but decrease CEO delta.

During the global financial crisis (GFC), banks experienced dramatic financial losses. Despite a positive merger-pay relation existent in most of our sample period, bank mergers significantly reduced CEO compensation during the breakout of the GFC. The dramatic losses suffered by banks, and the resulting illiquidity that plagued the real economy, demanded that policymakers take a closer look at the roots of the crisis. One common view is that the crisis is at least partly the result of exorbitant risk taking by banks (Bhagat and Bolton, 2014), which warrants regulative changes in the banking sector to incentivise bank managers properly through compensation design. Notwithstanding the Dodd-Frank Wall Street Reform and Consumer Protection Act of 2010 that created new rules to restrict managerial compensation in financial institutions, we document a positive effect of merger growth on CEO compensation and vega in the post-crisis period. This finding suggests that investing in M\&As is one way for bank CEOs to counter the regulatory intention of curbing excessive executive pay and risk taking.

Our paper contributes to the existing literature in the following respects. First, we clarify the impact of bank mergers on various aspects of $\mathrm{CEO}$ compensation, complementing the literature in the banking industry, such as Anderson et al. (2004) and Bliss and Rosen (2001). Specifically, we analyse the merger's effect on CEO compensation along all its three dimensions (overall level, composition and incentives), among which our most novel work lies in the analysis of CEO incentives embedded in postmerger compensation packages - namely, the merger-related shifts in delta and vega. To the best of our knowledge, we are the first to undertake such a comprehensive assessment of the merger-pay relation in banks.

Our results are generally consistent with Bliss and Rosen (2001), who focus on the level of compensation and show that CEO compensation increases after bank mergers. We substantially extend their study by examining how bank mergers shape CEO incentives. More importantly, it is unclear in Bliss and Rosen (2001) whether the increased CEO compensation subsequent to bank mergers is a result of optimal contracting that rewards talented CEOs who select profitable M\&A opportunities, or is driven by rent extraction motives of self-serving CEOs in anticipation of better remuneration following 
M\&As. Our evidence is supportive of the latter view and suggestive of the rent extraction purposes of acquiring CEOs, for two reasons: (1) bank mergers in our sample, on average, are associated with negative abnormal announcement stock returns and, thus, it is unlikely that the higher compensation after mergers represents managerial talent for seeking out value-increasing M\&A investments; and (2) acquiring CEOs are found to decouple their firm-specific equity wealth from the post-merger stock returns, indicative of post-merger CEO incentives being beneficial to CEOs themselves but sub-optimal for shareholders.

Our study is the first to compare the merger-pay relation between banks and industrial firms by using a DiD estimator. ${ }^{1}$ The significantly higher CEO compensation and lower CEO delta after bank mergers relative to matched mergers in industrial firms reflect a more severe agency problem in bank mergers. In addition, the previous studies for industrial firms, such as Grinstein and Hribar (2004), Harford and Li (2007), and Yim (2013), only examine the variation in the level of CEO compensation around M\&As and do not compare the change in CEO compensation due to merger growth with that due to non-merger internal growth. Our results based on a sample of industrial firms show that merger growth has a larger increasing effect on CEO compensation than non-merger internal growth, which highlights the efficacy of M\&As used as a device for industrial firm CEOs to raise their pay.

Second, a large literature has shown that firm size is a major driver of CEO compensation - larger firms pay their CEOs more (Baker et al., 1988; Conyon, 2014; Murphy, 1985; Murphy, 1999). However, the positive relation between firm size and CEO compensation does not necessarily imply that M\&As, among many ways to grow firms (e.g., internal sales growth, capital expenditures, and investment in research and development), benefit CEO compensation, as the majority of M\&As are value destroying for shareholders (e.g., Agrawal et al., 1992; Loughran and Vijh, 1997; Moeller et al., 2005; Rau and Vermaelen, 1998), which may not be rewarded by boards of directors of acquiring firms (see, e.g., Lambert and Larcker, 1988). The existing literature provides mixed evidence on this relation for industrial firms. Grinstein and Hribar (2004) and Harford and Li (2007) find that M\&As have a positive

\footnotetext{
${ }^{1}$ We thank the anonymous referee for suggesting the DiD approach for comparing bank mergers with mergers in industrial firms.
} 
effect on subsequent CEO pay, while Avery et al. (1998) do not find this effect. In the banking industry, the relation is also obscure. Bliss and Rosen (2001) find that CEOs in banks receive higher compensation after mergers. However, Anderson et al. (2004) find no such effect. Our paper helps clarify the unsettled merger-pay relation for bank CEOs. In particular, we advance the previous studies by differentiating the effects of bank expansion attained in two different ways - namely, M\&As and internal asset growth. We show that per-dollar amount of merger growth adds significantly more to CEO compensation than does the same dollar amount of non-merger internal growth.

Finally, our paper supplements the growing literature on executive compensation and the GFC. Bhagat and Bolton (2014) argue that the GFC can be attributed, at least in part, to the sub-optimal design of executive compensation, which motivates bank CEOs to take excessive risks. This necessitates regulative changes in the banking sector to incentivise CEOs properly through the arrangements of compensation. However, contradictory to the policy intention, our study finds evidence suggesting that the post-crisis regulatory changes in U.S. financial institutions play a rather limited role in curbing the merger-pay links. Expanding bank size via M\&As is one way for CEOs to increase their pay post-crisis. After the crisis, bank mergers led to CEO compensation structures with higher vega, which indicates that government intervention fails to discourage acquiring banks from providing their CEOs with risktaking incentives to take advantage of post-crisis new growth opportunities.

The remainder of this paper proceeds as follows. Section 2 provides literature and develops hypotheses. Section 3 describes the research methodology and sample. Section 4 presents our main results. Section 5 conducts additional analyses. Section 6 concludes this paper.

\section{LITERATURE AND HYPOTHESES}

\section{(i) Executive Compensation}

Research on executive compensation is based upon two predominant theoretical approaches. One is optimal contracting, which posits that executive compensation serves as a device to alleviate the conflict of interests between stakeholders. For example, shareholders may structure executive compensation to encourage managers to maximise firm value. As predicted by this approach, there exist optimal 
compensation contracts that are devised by boards of directors to minimise agency costs and to align managerial incentives with the interests of shareholders. However, the evidence is mixed regarding whether executive compensation has been properly designed to attain the incentive alignment aim. On the one hand, Murphy (1985) documents a positive relation between executive compensation and stock price, which suggests that the compensation rewards managerial efforts in increasing firm value. Hall and Liebman (1998) show that CEO compensation is responsive to stock price and that the responsiveness has risen sharply in the 1990s due primarily to a large increase in stock option grants. On the other hand, Bertrand and Mullainathan (2001), Jensen and Murphy (1990), and Murphy (1999) find that CEO compensation is only weakly linked to firm performance, making compensation underpowered as a tool to motivate CEOs to perform.

The other theoretical approach is the managerial power hypothesis, proposed by Bebchuk et al. (2002), who conceive executive compensation as part of agency problems. In this framework, powerful managers exert influence over boards of directors to structure their own compensation for their personal benefit at the expense of shareholders. In firms with diffused ownership, managers may behave opportunistically. They may capture boards (Shivdasani and Yermack, 1999) or hire compensation consultants who cater to their own interests (Murphy and Sandino, 2010). Under these circumstances, managers can use their substantial power to extract rents from the firms they manage. In particular, they can earn excess pay beyond the efficient level predicted by optimal contracting. In direct support, Morse et al. (2011) document a strong link between CEO power and higher pay. Bebchuk and Fried (2003) find that these powerful managers not only seek higher pay but detach their pay from the performance of their firms so that they can be overly compensated even when firms underperform. In addition, Lord and Saito (2012) find that CEOs can structure their compensation to reduce personal risk.

In fact, the two approaches - optimal contracting and managerial power - are not mutually exclusive, as neither offers a fully convincing explanation for the extant evidence. As Bebchuk et al. (2002) state, 'compensation arrangements are shaped both by managerial power and by what would be optimal' (p. 3).

Different forms of compensation provide managerial incentives to different degrees. A standard 
managerial compensation package consists of base salary, bonus, stock grants, option grants, long-term incentive payments, and other compensation such as perquisites and life insurance premiums. Much research has focused on its cash (salary and bonus) and equity (stock and options) components for improving the efficiency of incentive rewards. Baker et al. (1988) and Mehran (1995) both suggest that, in lieu of cash compensation that attaches CEO pay to past firm performance, equity compensation entails most of the incentives that are crucial in maximising shareholder value because CEOs are generally not allowed to trade or exercise newly granted equities in a predetermined vesting period (typically, five years), which creates long-term incentives for CEOs to benefit shareholder value. Consequently, stock and options have been increasingly used in executive compensation awards. This equity component has been seen as essential to linking CEO pay to firm performance and thereby aligning the interests of managers and shareholders. ${ }^{2}$

Estimating the value of CEO equity holdings, as well as its sensitivities to stock price and stock return volatility, is a principal goal of Core and Guay (1999) and Core and Guay (2002). The payperformance sensitivity (delta) quantifies CEOs' incentives to increase firm value by estimating the sensitivity of CEO equity wealth to stock returns. Although higher delta motivates CEOs to make more value-enhancing investments, CEOs with high delta may deliberately forgo positive net present value (NPV) investments that carry high risks. Guay (1999) finds that the convex payoffs from option-based compensation can counter this effect, as CEOs share the gains of option holdings when stock price rises but do not suffer all the losses when stock price falls. The incentives related to the convexity of compensation are measured by the sensitivity of CEO option wealth to stock return volatility (vega). ${ }^{3}$

Effective corporate governance can curb CEO rent extraction in compensation. Bertrand and

\footnotetext{
${ }^{2}$ However, it should be noted that the extensive use of equity compensation may engender undesirable outcomes. For example, Cheng and Warfield (2005) find that managers with higher equity compensation are more likely to manipulate reported earnings.

${ }^{3}$ Delta provides CEOs with an ambiguous incentive to take risks. On the one hand, as delta ties CEO equity wealth to stock price, it prompts CEOs to take on risky projects that are expected to increase shareholder value (Armstrong et al., 2015). On the other hand, as delta exposes CEOs to higher risks, it may discourage risk-averse CEOs from making risky investments (Coles et al., 2006). In contrast, there is clear evidence that high vega is associated with firm risk taking activities, including investment in research and development (Coles et al., 2006), aggressive debt policy (Gormley et al., 2013), earnings management (Armstrong et al., 2013), tax avoidance (Armstrong et al., 2015) and high equity cost (Chen et al., 2015).
} 
Mullainathan (2001) find that CEOs are paid less for luck in better-governed firms, such as firms with large shareholders sitting on boards. Hartzell and Starks (2003) show that higher institutional ownership concentration reduces managerial compensation and increases managerial pay-performance sensitivity, suggesting that institutional investors play a monitoring role in the pay-setting process. Chhaochharia and Grinstein (2009) document a decrease in CEO pay once board oversight is strengthened. Hsu and Liao (2012) show that auditors' detection of firms' internal control problems materially reduces executive compensation.

Executive compensation is also a focus of research in the banking industry. A majority of the literature examines the pay-performance relation. Barro and Barro (1990) find that bank CEO compensation is sensitive to bank performance. The sensitivity is associated with CEO experience (Barro and Barro, 1990), managerial discretion (Magnan and St-Onge, 1997), board independence (Mishra and Nielsen, 2000), and outside monitoring by non-depository debt holders and regulators (John et al., 2010). Hubbard and Palia (1995) show that the permission of interstate banking significantly increases CEO pay and pay-performance sensitivity. Related, Cuñat and Guadalupe (2009) show that bank CEO compensation becomes more equity-based and more sensitive to bank performance following two major banking deregulations. ${ }^{4}$ In contrast to the above studies, which document a significant pay-performance link, Fahlenbrach and Stulz (2011) find that bank CEOs with greater compensation incentives to raise bank value did not perform better during the financial crisis.

Another line of research studies the relation between compensation and bank risk taking. Belkhir and Chazi (2010) and DeYoung et al. (2013) find that banks in which CEOs have higher pay-risk sensitivity tend to take higher risks. Hagendorff and Vallascas (2011) show that high pay-risk sensitivity motivates bank CEOs to undertake M\&As that increase the default risk of banks. Bebchuk and Spamann (2010) argue that equity awards generate excessive risk-taking incentives for bank CEOs and that this problem cannot be eliminated through corporate governance reforms. Thanassoulis (2014) suggests that a compensation cap in proportion to bank assets can be set to reduce bank risk but increase

\footnotetext{
${ }^{4}$ The two deregulations are the removal of interstate banking restrictions, and the consolidation of commercial banking, investment banking and insurance services.
} 
bank value.

\section{(ii) Merger Activity and Executive Compensation}

Acquirer shareholders, on average, do not profit from M\&As. The stock market responds negatively to most M\&A announcements (e.g., Agrawal et al., 1992; Loughran and Vijh, 1997; Moeller et al., 2005; Rau and Vermaelen, 1998). The aggressive expansion of firm size comes at the expense of shareholder value and could be viewed as attempts of acquirer managers to seek personal benefit. ${ }^{5}$ Drawing on the fact that managers in larger firms are generally paid more (Baker et al., 1988; Conyon, 2014; Murphy, 1985; Murphy, 1999), several studies have explored how executive compensation changes following M\&As, resulting in two major views.

The first view contends that managers raise their compensation and wealth by pursuing M\&As that substantially enlarge firms. Conyon and Gregg (1994) analyse the merger-pay relation in U.K. firms, showing that firm expansion through M\&As significantly elevates CEO compensation, which in turn, however, does not increase shareholder returns. Grinstein and Hribar (2004) show that, in U.S. firms, CEOs with more power over boards tend to enter larger M\&A deals and receive higher bonuses, which is shown to cause the acquirer's stock price to decline. Harford and Li (2007) find that CEOs have an incentive to undertake M\&As, as they will be rewarded with a considerable amount of equity compensation, which increases their subsequent wealth even when the stock market reacts negatively to the M\&As. Bugeja et al. (2012a) find that acquiring CEOs in Australian firms receive higher compensation in all the components of their compensation packages. Yim (2013) reveals that M\&As give rise to large permanent growth in CEO pay, which encourages CEOs to make M\&As early in their careers.

\footnotetext{
${ }^{5}$ CEO pay is positively related to firm size (e.g., Baker et al., 1988; Conyon, 2014; Murphy, 1985; Murphy, 1999). This is not surprising because larger firms, in which managerial tasks are more complex, demand more skilled CEOs to manage them. The CEOs, therefore, receive higher pay. Nonetheless, the pay-size relation cannot be fully justified by managerial skills. Murphy (1985) finds that the positive pay-size relation holds irrespective of stock price changes, which suggests that CEOs obtain higher pay simply by expanding firm size even when the expansion destroys shareholder value. Bebchuk and Grinstein (2005) document that CEOs are paid more when they expand firm size but are not paid less when firm size decreases. Furthermore, there is evidence that CEO pay in larger firms is less sensitive to stock price (e.g., Baker and Hall, 2004; Jensen and Murphy, 1990; Murphy, 1999; Schaefer, 1998). Overall, the results are consistent with the notion in Hope and Thomas (2008) and Jensen (1986) that CEOs realise self-serving gains at the expense of shareholders through empire building.
} 
The alternative view is that managers undertake M\&As to boost their power and prestige from running a larger, more complex firm after the consolidation, which does not necessarily lead to larger compensation or greater wealth. This argument is supported by Lambert and Larcker (1988), who find that the value-reducing M\&As that most firms engage in do not lead to wealth increase as the large post-merger decrease in the value of equity holdings outweighs the small increase in cash compensation. Similarly, Khorana and Zenner (1998) show that the positive impact of M\&As on executive compensation is rather small and that M\&As that reduce shareholder value do not increase executive compensation. A related study by Avery et al. (1998) documents that CEOs who invest in M\&As do not experience larger compensation growth than CEOs who make no M\&A investments, whether or not the M\&As are profitable for shareholders. These authors further argue that undertaking M\&As benefits CEOs because managing larger firms improves CEO prestige and status within the business community.

The arrangements of executive compensation also have an impact on corporate M\&A decisions. Cai and Vijh (2007) find that CEOs who hold more equities are more likely to make M\&As and tend to buy undervalued targets using more stock-based payments. Seo et al. (2015) find that CEOs who are underpaid relative to their peers are more likely to engage in M\&As to raise their own compensation. Williams and Rao (2006) show that CEO pay-risk sensitivity is positively associated with equity return volatility subsequent to M\&As. Croci and Petmezas (2015) find that CEOs with higher pay-risk sensitivity are more likely to undertake M\&As.

The empirical work on the merger-pay relation in banks is relatively scarce. The study by Bliss and Rosen (2001) reports a significant increase in post-merger compensation for CEOs in banks, and the increase in compensation is found to arise primarily from large cash rewards to CEOs. Their study also shows that bank CEOs with higher levels of equity compensation are less likely to engage in M\&As, as CEO equity wealth would diminish due to the typical negative stock market reactions to M\&As. Anderson et al. (2004) find that the post-merger changes in CEO pay are positively associated with the combined returns to acquirer and target shareholders around merger announcements. Minnick et al. (2011) show that banks whose CEOs have higher pay-performance sensitivity are more likely to make value-increasing acquisitions and experience larger performance enhancements following acquisitions. 


\section{(iii) Hypotheses Development}

We develop our hypotheses along the three dimensions of CEO compensation - the level, composition and functional form. The first dimension (level) is the total value of a CEO's compensation package. The second dimension (composition) is the dollar value of each compensation component, including equities, cash and many others (e.g., perquisites, insurance and long-term incentive payments). The third dimension (functional form) describes the incentive structure of the compensation package. Two relevant measures are delta and vega. Since our study aims to clarify whether bank CEOs earn selfserving compensation contracts through M\&As, we formulate our hypotheses based on the managerial power approach in which executive compensation is viewed as part of agency problems and is employed by powerful managers to enhance their own benefits.

Murphy (1985) shows that CEO compensation increases with firm size regardless of whether the size expansion leads to value creation. That is, CEOs can be better remunerated simply by enlarging firms, even when the aggressive expansion diminishes shareholder value. A common way in which firm size can be rapidly increased is M\&As, which are frequently followed by substantial declines in stock price. Although firms often refer to synergy gains to justify their merger decisions, some unobservable empire-building aspects, such as CEOs' desire for status, power and new fields of business, also motivate these firm-expansion decisions (e.g., Amihud and Lev, 1981; Black, 1989; Ravenscraft and Scherer, 2011; Trautwein, 1990). Acquiring CEOs typically obtain greater decision-making power from managing a larger, consolidated enterprise. According to the managerial power hypothesis (Bebchuk and Fried, 2003; Bebchuk et al., 2002), we expect that these acquiring CEOs exercise their increased power to capture the pay-setting process so as to earn higher levels of pay from the consolidated banks. Formally, we hypothesise:

\section{Hypothesis 1: Asset growth through bank mergers increases CEO total compensation.}

In principle, firms can utilise cash bonuses to fully remunerate managers for their efforts in improving firm performance. However, in practice, firms do not heavily use cash bonuses as incentive pay. As discussed in Baker et al. (1988), large monetary rewards can lead managers to focus narrowly on achieving tasks and constrain intrinsic interests that managers may pursue through efforts, which 
together destroy managers' motivation to perform. Boards of directors thus often refrain from paying large cash amounts to managers (Bebchuk and Fried, 2003). It would be difficult for CEOs to make their compensation more cash-based than equity-based. In addition, the huge disparity in the levels of monetary rewards between CEOs and employees constitutes severe compensation disparity within the firms, which may diminish employees' enthusiasm about enhancing firm productivity (Baker et al., 1988). Moreover, since equity compensation, which is closely linked to firm performance, appears to align the best interests of CEOs and shareholders, largely increasing equity pay rather than cash pay is relatively more justifiable in the highly regulated banking industry, especially when most acquirers perform poorly after M\&As. Therefore, it is likely that the increase in total compensation due to mergers arises from large equity grants rather than cash rewards. We expect that acquiring CEOs receive higher levels of equity compensation after mergers and that the increase in cash compensation is negligible. Formally, we hypothesise:

Hypothesis 2a: Asset growth through bank mergers increases CEO equity compensation.

Hypothesis 2b: Asset growth through bank mergers does not affect CEO cash compensation.

Next, we investigate how CEO delta shifts after bank mergers. According to the managerial power hypothesis, managers tend to capture the pay-setting process to obtain favourable compensation contracts. The rapid bank growth via M\&As expands CEOs' decision-making power to seek such rents. The increased power subsequent to M\&As could allow CEOs to detach their equity wealth from bank performance. Given the large evidence showing that acquirers experience remarkable stock price declines during the few years following merger completion (Agrawal et al., 1992; Loughran and Vijh, 1997; Rau and Vermaelen, 1998), acquiring CEOs have strong incentives to disconnect their equity wealth from the underperformed stock price in order to reduce their losses incurred. Therefore, we expect a decrease in CEO delta following bank mergers. Formally, we hypothesise:

Hypothesis 3: Asset growth through bank mergers decreases CEO delta.

The effect of bank mergers on CEO vega is less clear. On the one hand, CEO vega may decrease after bank mergers. Generally, CEOs, like many other top managers, are risk-averse (Mehran, 1995). To the extent that risk-averse CEOs may forgo some risky investments that are value-enhancing for 
shareholders (Smith and Stulz, 1985), acquiring CEOs may seek rents that reduce the sensitivity of their equity wealth to bank risk (i.e., lower vega), so that they will be less constrained in their risk-avoiding behaviour. On the other hand, CEO vega may increase after bank mergers. Guay (1999) suggests that CEO vega is shaped by firms' investment opportunity set. In his view, the costs of abandoning risky but positive NPV projects are particularly high in firms with abundant investment opportunities, such as M\&A investments. To reduce the risk-related agency costs, boards of directors may elect to give CEOs greater incentives to undertake these risky investments (i.e., higher vega). As can be seen, the net effect of bank mergers on $\mathrm{CEO}$ vega is a result of the $\mathrm{CEO}$ risk-aversion effect weighed against the shareholder wealth effect. We thus present our hypothesis in null form:

Hypothesis 4: Asset growth through bank mergers does not affect CEO vega.

\section{MODEL AND DATA}

\section{(i) Research Design}

We examine the impact of bank growth through mergers on CEO pay and pay sensitivity using the following regression models:

CEO pay ${ }_{i, t}$

$$
\begin{aligned}
& =\alpha_{0}+\alpha_{1} \text { Total assets }_{i, t-3}+\alpha_{2} \text { Assets acquired in megamergers } s_{i, t} \\
& +\alpha_{3} \text { Non-megamerger growth } \\
& +\alpha_{4} \text { Change in firm value due to change in industry index } \text { in }_{i, t} \\
& +\alpha_{5} \text { Change in firm value due to idiosyncratic chang } e_{i, t} \\
& +\alpha_{6} \text { Return on assets }_{i, t}+\alpha_{7} \text { Female CEO } O_{i, t}+\alpha_{8} \text { CEO duality } y_{i, t} \\
& +\alpha_{9} \text { CEO age } e_{i, t}+\alpha_{10} \text { CEO shareholding }{ }_{i, t}+\sum_{k} \alpha_{k} \text { Year dummy } y_{k, i, t}+\varepsilon_{i, t}
\end{aligned}
$$

CEO pay sensitivity ${ }_{i, t}$

$$
\begin{aligned}
& =\beta_{0}+\beta_{1} \text { Total assets } \text { a }_{i, t-3}+\beta_{2} \text { Assets acquired in megamergers }{ }_{i, t} \\
& +\beta_{3} \text { Non-megamerger growth }{ }_{i, t} \\
& +\beta_{4} \text { Change in firm value due to change in industry index } x_{i, t} \\
& +\beta_{5} \text { Change in firm value due to idiosyncratic change } e_{i, t} \\
& +\beta_{6}{\text { Return on } \text { assets }_{i, t}+\beta_{7}{\text { Female } C E O_{i, t}}+\beta_{8} \text { CEO duality }}_{i, t} \\
& +\beta_{9} \text { CEO age }_{i, t}+\beta_{10} \text { CEO shareholding }{ }_{i, t}+\sum_{k} \beta_{k} \text { Year dummy } \text { I }_{k, t}+\varepsilon_{i, t}
\end{aligned}
$$

where $i$ indexes firm, and $t$ indexes year. In equation (1), CEO pay is measured by three different variables: (1) total compensation is the sum of salary, bonus, value of stock grants, Black-Scholes value 
of stock option grants, other annual compensation (e.g., perquisites and other personal benefits), longterm incentive payments and all other compensation (e.g., debt forgiveness and life insurance premiums); (2) equity compensation is the value of stock and stock option grants; and (3) cash compensation is salary plus bonus. A large body of early literature, such as Bliss and Rosen (2001) and Datta et al. (2001), exploits equity compensation as a proxy for the incentives embedded in CEO compensation. However, this approach only accounts for the stock and options newly granted to CEOs and excludes the incentives derived from the dollar change in CEOs' existing equity holdings. With this caveat in mind, we follow Core and Guay (2002) and Coles et al. (2006) to calculate CEO pay sensitivity, which captures CEOs' incentives arising from their newly granted and previously held equities. In equation (2), CEO pay sensitivity is measured by (1) the pay-performance sensitivity (delta), calculated as the dollar change in the value of CEO stock and stock option portfolio given a $1 \%$ change in the stock price; and (2) the pay-risk sensitivity (vega), calculated as the dollar change in the value of CEO stock option portfolio given a 0.01 change in the standard deviation of stock returns ${ }^{6}$ CEOs with higher delta have stronger incentives to improve stock price performance, while CEOs with higher vega have stronger incentives to take risks.

We identify a sample of megamergers whose transaction value exceeds $10 \%$ of the acquirer's market capitalisation measured 20 trading days prior to the merger announcement date. Since they are economically significant capital events and are very likely to affect CEO compensation arrangements, we focus our analyses on these megamergers. To ensure robustness, and also to gain some insight into bank merger strategy, we additionally test our hypotheses using the sample of all mergers, disregarding the deal size.

It may take time for M\&As to exert an impact on CEO compensation arrangements. ${ }^{7}$ As such, we examine how asset growth through bank mergers completed over the prior three years affects CEO pay

\footnotetext{
${ }^{6}$ Guay (1999) shows that the sensitivity of CEO equity portfolio (including both stock and stock options) to stock return volatility is driven primarily by stock options. Consistent with the convention in the literature (e.g., Armstrong et al., 2013; Core and Guay, 2002; Coles et al., 2006), we assume stock vega equal to 0 and use option vega as a proxy for the vega of CEO equity portfolio.

${ }^{7}$ CEO compensation contracts typically last five years (Murphy, 1999).
} 
and pay sensitivity of the current year. To differentiate between asset growth through bank mergers and non-merger internal growth, we construct the following explanatory variables. Total assets at $t-3$ is the book value of total assets at the end of year $t 3$. Assets acquired in megamergers is the value of total assets acquired via megamergers from the end of year $t-3$ to the end of year $t$. Non-megamerger growth is non-megamerger internal asset growth over the prior three years, calculated as the book value of total assets at the end of year $t$ minus Total assets at $t-3$ and Assets acquired in megamergers. For all merger activities, Assets acquired in all mergers is the value of total assets acquired via all mergers over the previous three years, and Non-merger growth is non-merger internal asset growth over the same threeyear period. As some targets are private firms and their financial data are not easily accessible, we use deal size to measure the value of assets acquired.

Since CEOs in better-performing firms are generally paid more (Core et al., 1999; Murphy, 1999), our models control for the performance of banks. Specifically, to capture bank performance in stock markets, two variables are created to distinguish between the change in stock price related to industrywide fluctuations and that related to idiosyncratic stock price movements: (1) Change in firm value due to change in industry index is the dollar change in the bank's equity value from the end of year $t \rightarrow 3$ to the end of year $t$, given the percentage change equal to the value-weighted banking industry index return; and (2) Change in firm value due to idiosyncratic change is the dollar change in the bank's equity value due to firm-specific stock price movements, which is calculated as the total dollar change in the bank's equity value over the prior three years minus Change in firm value due to change in industry index. Return on assets is included to measure the accounting performance of banks. Due to the significant effects of executive characteristics on compensation arrangements (Bugeja et al., 2012b; Cyert et al., 2002), our models also control for a variety of CEO characteristics, such as CEO gender (Female CEO) and age (CEO age). Additionally, CEO duality is incorporated as a measure of CEO power, and is set equal to 1 if the $\mathrm{CEO}$ is also the chairman of the board, and 0 otherwise. CEO shareholding is the shares held by the CEO as a percentage of the bank's total shares outstanding. All the variables are defined in the appendix. Year dummies are included to capture macroeconomic, regulatory and aggregate shifts in CEO pay and pay sensitivity across years. The models are then estimated using ordinary least squares (OLS) regressions with robust standard errors corrected for firm-level clustering. 


\section{(ii) Sample Construction}

Our sample comprises all publicly listed bank holding companies (SIC code 6000-6099) in the United States. We obtain their domestic M\&A data from the Securities Data Corporation (SDC) database. We include an M\&A transaction in our analyses if it satisfies the following criteria: (1) the transaction is completed; (2) the transaction value exceeds \$1 million; and (3) the acquirer owns more than $50 \%$ of the target's shares after the transaction, where the target can be a private firm and not necessarily a bank. The M\&A data are then matched with executive compensation data from Execucomp, firm-level accounting data from Compustat and stock market data from CRSP. These procedures yield a sample of 1,753 bank-years from 184 banks for the period 1992-2014. ${ }^{8}$

\section{(iii) Distribution of Bank Mergers}

Table 1 reports bank merger distribution and deal characteristics by merger completion year. In past waves of banking consolidation, the number of megamergers (mergers) made by banks rises from 2 (11) in 1992 to the peak of 34 (117) in 1998. The peak period roughly coincided with the enactment of the Gramm-Leach-Bliley Financial Services Modernization Act of 1999, which allowed commercial banks to acquire other financial service providers. This trend of merger activity in banks is very similar to that documented by Masulis et al. (2007) and Moeller et al. (2004) in industrial firms. Over the years since 2000, banking consolidation intensity has gradually weakened, despite 2004 being the height of the recent wave. Over the entire sample period, megamergers account for about $78 \%$ of the transaction value of all mergers. The megamergers, on average, make up $31.62 \%$ of the pre-megamerger market capitalisation of acquiring banks. The stock market generally responds negatively to M\&A announcements made by acquiring banks, ${ }^{9}$ which is consistent with the findings of Anderson et al. (2004) and Grinstein and Hribar (2004). The cumulative abnormal return (CAR) from day -2 to day +2 (in trading days) around an average megamerger (merger) announcement is $-1.71 \%(-0.78 \%)$, where

\footnotetext{
${ }^{8}$ Execucomp compensation data is available from 1992.

${ }^{9}$ In Panel A of Table 1, the average CAR $[-2,+2]$ and $[-2,+250]$ in 2009 are $41.70 \%$ and $109.12 \%$, respectively. The large positive stock return is due to the large cash dividends paid by acquiring banks on the megamerger announcement day.
} 
day 0 is the megamerger (merger) announcement date. ${ }^{10}$ The mean CAR from day -2 to day +250 is $3.41 \%$ in the megamerger sample and $-7.51 \%$ in the all-merger sample, suggestive of a long-run postmerger stock price underperformance of acquiring banks.

\section{$<<$ Insert Table 1 about here $>>$}

\section{(iv) Sample Characteristics}

Table 2 presents descriptive statistics for CEOs in banks. In Panel A, a bank CEO's total compensation ranges from $\$ 0.38$ to $\$ 23.26$ million. In banks, $52.4 \%$ of $\mathrm{CEO}$ total compensation is paid out in the form of stock and options, with an average equity compensation of $\$ 2.12$ million, while $31.5 \%$ is in the form of cash, with an average cash compensation of $\$ 1.27$ million. On average, a positive stock return of $1 \%$ brings about an increase of $\$ 507,000$ in the value of CEO stock and stock option portfolio, while a 0.01 increase in the standard deviation of stock returns corresponds to an increase of $\$ 126,000$ in the value of CEO stock option portfolio. Mergers are infrequent capital events. The change in bank size is due primarily to internal asset growth, with the average dollar amount of non-megamerger internal growth equal to $\$ 16.68$ billion and the average dollar amount of assets acquired in megamergers over the past three years equal to $\$ 1.03$ billion. In addition, only $2.5 \%$ of bank CEOs are female. About $63.7 \%$ of CEOs serve as board chairs. The CEOs on average hold $1.2 \%$ of the shares outstanding in their banks. The variation in bank equity value over the prior three years is driven mainly by industry-wide stock return movements rather than by idiosyncratic stock price changes. The sample banks report an average return on assets of $2.5 \%$. More than half of bank shares are held by institutional investors, with an average percentage of institutional stock holdings of $55.7 \%$. The average bank board consists of nearly 13 directors, among whom $74.5 \%$ are independent directors. Panel B reports average CEO pay and pay sensitivity across sample years. There was an upward trend in CEO total compensation before 2000, which thereafter declined slightly. The rapid increase in CEO pay generally coincided with bank merger waves.

\footnotetext{
${ }^{10}$ The expected return used to compute the CAR comes from a market model with the CRSP value-weighted index return as the market return over an estimation window $[-250,-20]$ prior to the announcement date.
} 


\section{MAIN RESULTS}

\section{(i) Determinants of Bank Merger Announcements}

Identifying the causal effect of merger growth on $\mathrm{CEO}$ compensation is challenging. CEOs who anticipate that M\&A announcements will adversely affect their personal equity wealth may structure their compensation or equity holdings in advance of the announcements. The incentives embedded in their compensation may also impact on their M\&A decisions. These possibilities would lead to a reverse causation from CEO compensation to bank M\&As. Thus, it is important to assess whether CEO compensation can influence the decision of banks to undertake M\&As. Our exploration is based on an analysis of the likelihood of megamerger announcements as a function of CEO pay and pay sensitivity. The regressions are estimated using a probit model in which the dependent variable takes the value of 1 if at least one megamerger announcement is made by a bank in a given year, and 0 otherwise. ${ }^{11}$ The right-hand side of the model incorporates the compensation measures of major interests, as well as control variables that have been shown to influence corporate M\&A decisions (Byrd and Hickman, 1992; Levi et al., 2010; Shivdasani, 1993), including Return on assets, Market-to-book, Leverage, Sales growth, Cash holdings, Ln(Total assets), Institutional ownership, Institutional ownership concentration, Board independence, Board size, Female CEO, CEO duality, CEO age and CEO shareholding. The independent variables are lagged by one year relative to the dependent variable.

In Panel A of Table 3, we present regression results on the determinants of bank megamerger announcements. In column 1, we find that the level of CEO total compensation is positively associated with the likelihood of megamerger announcements. For the different components of the total compensation, we observe in column 2 that the level of equity compensation significantly increases megamerger propensity, while the level of cash compensation is statistically insignificant in predicting the propensity. The increasing effect of CEO total compensation on megamerger announcements is,

\footnotetext{
${ }^{11}$ The results based on all-merger announcements are qualitatively unchanged.
} 
thus, due primarily to the effect of its equity component. Our results suggest that higher levels of equity compensation incentivise CEOs to undertake megamergers. In column 3, we find that CEO delta has no significant impact on bank megamerger announcements. CEO vega is positively and significantly related to the announcements, consistent with the finding of Croci and Petmezas (2015) for industrial firms. In terms of economic significance, in column 5, a one-unit increase in CEO equity compensation increases the odds ratio of megamerger announcements by $4.6 \%$, and a one-unit increase in CEO vega increases the odds ratio by $82.9 \%{ }^{12}$ To reduce the undue effect of time-invariant bank factors (e.g., bank culture) on the results, we rerun the regressions using a linear probability model with firm-level fixed effects. The relations shown in Panel B of Table 3 remain qualitatively unchanged.

$$
<<\text { Insert Table } 3 \text { about here }>>
$$

\section{(ii) Impact of Bank Mergers on CEO Compensation}

In Table 4, we present regression results of the impact of merger growth on CEO pay and pay sensitivity. In columns 1-2 of Panel A, the coefficients on merger growth are positive and significant at the $1 \%$ level, lending support to our hypothesis that asset growth through bank mergers increases CEO total compensation. With respect to the components of the compensation, columns 3-6 show that merger growth has a significantly positive impact on CEO equity compensation but no significant impact on CEO cash compensation. A one-standard-deviation increase in Assets acquired in megamergers is associated with a $26.41 \%(=(0.1875 \times 5.699) / 4.046)$ increase in the total compensation as reported in column 1 and a $45.29 \%(=(0.1684 \times 5.699) / 2.119)$ increase in the equity compensation as shown in column 3. Moreover, we find that CEO compensation is also positively related to non-merger internal asset growth. Jointly, the results suggest a positive link between CEO pay and bank growth regardless of the ways in which the growth is achieved. Nonetheless, it is noteworthy that non-merger internal growth adds significantly less to CEO pay than does asset growth via mergers. In column 1 of Panel A,

\footnotetext{
${ }^{12}$ We calculate the increase in the likelihood of megamerger announcements due to the change in CEO pay and pay sensitivity based on coefficient estimates reported in column 5 of Table 3 . For a one-unit increase in equity compensation, the increase in the likelihood of megamerger announcements $=\exp (0.0450)-1=4.6 \%$. For a oneunit increase in vega, the increase in the likelihood of megamerger announcements $=\exp (0.6037)-1=82.9 \%$.
} 
the coefficient on Assets acquired in megamergers is 0.1875 , which is significantly larger in magnitude than the coefficient of 0.0135 on Non-megamerger growth. The difference between the coefficients is 0.1740 with a statistically significant $t$-statistic of 4.35 . The magnitude of the coefficients means that $\$ 1$ million of new assets acquired through megamergers leads to an increment of $\$ 187.5$ in CEO total compensation; by contrast, per $\$ 1$ million of non-megamerger internal growth, the total compensation increases by only $\$ 13.5$. Thus, compared to non-merger internal growth, investing in M\&As is a more effective, rapid way for CEOs to increase their pay.

\section{$<<$ Insert Table 4 about here $>>$}

In Panel B, we present results of the impact of bank growth on the incentives derived from CEO compensation plans. Merger growth is negatively related to CEO delta, which highlights the intensified agency problem existent in CEO compensation subsequent to bank mergers. In line with the managerial power hypothesis, this relation suggests that CEOs with more decision-making power after M\&As tend to decouple their wealth from banks' stock price performance in order to reduce their personal losses as most banks perform poorly following M\&As. By comparison, non-merger internal growth is positively related to $\mathrm{CEO}$ delta, indicating that banks that grow internally to become large tend to provide proper incentives for CEOs to increase bank value. Overall, the results suggest that non-merger growth better aligns the incentives of CEOs with the interests of shareholders, whereas merger growth exacerbates the agency problem. While we do not find that merger growth exerts a significant impact on CEO vega, non-merger internal growth is shown to increase CEO vega, which corroborates the argument of Belkhir and Chazi (2010) that larger firms generally have a larger set of positive NPV investment opportunities that may carry excess risks and, thus, grant their CEOs stronger incentives to undertake these risky investments.

For the effects of control variables, we find that better-performing banks reward their CEOs better. In particular, industry-wide stock price increases have a larger increasing impact on CEO pay than firmspecific idiosyncratic stock price increases. CEO pay is positively related to the accounting performance of banks, as measured by return on assets. Moreover, female CEOs receive lower cash compensation than their male counterparts. CEOs who act as board chairs are better remunerated and have more incentives to improve bank performance and to take risks. CEOs with larger equity holdings have lower 
total and cash compensation but higher pay-performance sensitivity, which indicates that equity grants, as a substitute for cash awards, can incentivise bank CEOs to make value-increasing investments.

\section{(iii) Endogeneity}

There are two primary sources of endogeneity that could confound our results. One is reverse causality; that is, CEO pay or pay sensitivity may affect bank decisions to acquire other firms. The results in Table 3 suggest that our findings are plagued with this issue. The other endogeneity threat is from the possible existence of unobserved factors that correlate with CEO compensation or incentives and also determine bank merger decisions. To alleviate these endogeneity concerns, we employ three different approaches.

\section{(a) Firm-Fixed Effects Regressions}

In Table 5, we rerun the baseline OLS regressions with additional controls for firm-level fixed effects. This helps to rule out the concern that some omitted time-invariant firm-level heterogeneity may drive the relation between CEO pay (pay sensitivity) and bank mergers. The fixed effects regression results show that asset growth through bank mergers significantly increases the level of total compensation and, more specifically, the level of its equity component. In addition, CEO delta declines following bank mergers, indicating that CEO firm-related equity wealth is less tied to the bank's post-merger stock price. Notably, the results become relatively less significant after controlling for firm-fixed effects. This is because M\&As are infrequent capital events, providing little temporal change in merger growth variables for fixed effects identification. Overall, the results support our main conclusions.

\section{$<<$ Insert Table 5 about here $>>$}

\section{(b) Dynamic OLS Model and Dynamic Panel GMM Estimator}

In Table 3, we have shown that the occurrence of bank merger announcements depends on past levels of CEO compensation. The positive impact of merger growth on CEO compensation documented in Table 4 could be a result of reverse causality. According to Wintoki et al. (2012), the link between current merger decisions and past compensation arrangements should be accounted for by using a dynamic model with lagged compensation as a regressor, which can partially control for such reverse 
causality. In Panel A of Table 6, we incorporate two lags of CEO pay to the right-hand side of the baseline regression model. ${ }^{13}$ This dynamic model is then estimated using OLS regressions. The results show that total compensation and equity compensation are positively and significantly related to their respective first and second lags, while cash compensation is positively and significantly related only to its first lag. The dynamic model complements our baseline static model economically as well as statistically. The adjusted $R^{2}$ in the regression of total compensation rises from $44 \%$ in the static model in column 1 of Table 4 to $63 \%$ in the dynamic model in column 1 of Panel A of Table 6. Most importantly, the relations between CEO pay and merger growth remain valid in the dynamic OLS model.

\section{$<<$ Insert Table 6 about here $>>$}

However, our results may still suffer from the omitted variable problem. Wintoki et al. (2012) argue that in the presence of a dynamic relation, simply employing firm-fixed effects to alleviate this endogeneity concern could cause biases, as fixed effects estimation is powerful under an assumption that past values of the dependent variable have no impact on current values of any independent variable. Wintoki et al. (2012) point out that the dynamic panel system GMM estimator can account for the dynamic nature of the model and also control properly for constant unobserved firm-level heterogeneity. They stress that the dynamic panel GMM estimator should include enough lags of the dependent variable to ensure dynamic completeness - the lags are sufficient to capture all the impact of the past on the present. In Panel A of Table 6, we choose the lag length based on whether the lagged dependent variable included in the dynamic OLS model is statistically significant. For example, only the first lag of cash compensation is included in the dynamic GMM estimation because only the first lag is shown in the dynamic OLS regression to be statistically influential. We treat all independent variables in the model as endogenous except for year dummies. These endogenous variables are instrumented by two of their past values.

In Panel A of Table 6, we re-examine the merger-pay relation by using the dynamic GMM estimator. The results are consistent with our previous findings. We carry out two diagnostic tests to

\footnotetext{
${ }^{13}$ The results reported are based only on the megamerger sample. The results for all merger activities (untabulated) are qualitatively similar.
} 
assess the validity of the dynamic GMM specification. First, we test whether we have included enough lags of the dependent variable to make the model dynamically complete. If the lags are sufficient, the AR(1) tests should reject the null hypothesis of no first-order autocorrelation in the first-differenced residuals, but the $\mathrm{AR}(2)$ tests should fail to reject the null of no second-order autocorrelation. It is shown that our results pass AR(1) and AR(2) tests. Second, we conduct the Hansen J test of over-identification under the null hypothesis that all instruments are exogenous. We fail to reject the null, which indicates that all the instruments specified in the dynamic GMM estimator are valid.

For the impact of merger growth on CEO delta and vega, we apply similar dynamic OLS and dynamic panel GMM estimators to the model. Panel B of Table 6 shows that asset growth via megamergers significantly reduces CEO delta, but does not significantly affect CEO vega. The dynamic GMM diagnostic tests report that the specification is dynamically complete (i.e., pass AR(1) and AR(2) tests) and that the instruments are exogenous (i.e., Hansen J statistics are insignificant). The regression results corroborate our main conclusions.

\section{(c) DiD Estimator Combined with Propensity Score Matching}

We use a DiD estimator to compare the change in CEO compensation in acquiring banks before and after megamergers to that in matched control banks without megamerger activity during the same time period. The DiD estimator helps to address the endogeneity issue in two respects. First, it controls for time-invariant firm-level heterogeneity for both treatment and control banks as it is estimating the variation in CEO compensation surrounding megamergers within each bank. Second, it compares treatment banks to control banks over the same time period and thereby controls for the aggregate change in CEO compensation due to unobserved common trends that affect the two groups of banks in the same way. In particular, the staggered completion of megamergers made by different banks reduces the confounding effects of concurrent non-merger events.

We carry out the DiD analysis over a five-year event window centred on the megamerger completion year - two years before and two years after the megamerger - to ensure that the time is sufficient for megamergers to make an impact on CEO compensation. We focus on megamergers instead of all mergers for two reasons. First, the all-merger sample consists of a large number of small 
mergers whose impact on CEO compensation could be rather limited. Second, to identify the effect of a single merger on CEO compensation, treatment banks must have no merger activity during the two years before and two years after the merger completion year. The all-merger sample spans less discretely over the sample period, making such a sample less easily obtainable. In addition, the CEO of a treatment bank must not be replaced in the five-year event window, such that the change in CEO compensation is not caused by any changes in CEO characteristics due to the replacement. A control bank must be neither a target nor a bidder in megamergers over the same five years, and nor must its CEO be changed.

We match acquiring banks (treatment group) and non-acquiring banks (control group) using a one-to-one nearest neighbour PSM with replacement. As shown in Table 3, banks do not arbitrarily make their M\&A choices, and certain bank characteristics may drive their decisions. PSM enables us to find a sample of non-acquiring banks with no significant differences to treatment banks in these characteristics, which helps to mitigate the selection bias related to observed bank factors that predict M\&A occurrence. To calculate the propensity scores for each treatment and control bank, we estimate a probit regression in which the dependent variable is equal to 1 if a megamerger is completed in a given year, and 0 otherwise. The probit regression controls for all explanatory variables in column 1 of Table 3, except that: (1) for DiD estimation of CEO pay in Panel A of Table 7, the level of CEO total compensation in column 1 of Table 3 is replaced with the changes in CEO compensation (i.e., $\Delta$ Total compensation, $\Delta$ Equity compensation and $\Delta$ Cash compensation) over the three years prior to the megamerger completion year; and (2) for DiD estimation of CEO pay sensitivity in Panel B of Table 7, it is replaced with the changes in CEO pay sensitivity (i.e., $\Delta$ Delta and $\Delta V e g a$ ). This is to ensure the satisfaction of parallel trend assumption, a key identifying assumption behind the DiD estimator. It requires the same pre-megamerger trend in CEO pay (pay sensitivity) for both the treatment and control groups but does not require the level of CEO pay (pay sensitivity) to be identical during the premegamerger era. To ensure the internal growth of non-acquiring banks comparable to the mergerrelated growth of acquiring banks, the probit regression additionally controls for bank growth, which is defined as the dollar amount of assets acquired in megamergers for treatment banks and as the dollar amount of internal asset growth for control banks. After generating the propensity scores and matching 
each treatment bank to its nearest-neighbour control bank, we are left with a sample of 45 megamergers for the DiD analysis of CEO pay and another sample of 50 megamergers for the DiD analysis of CEO pay sensitivity.

\section{$<<$ Insert Table 7 about here $>>$}

To test the validity of the matching, we first examine the difference in propensity scores between the treatment and control groups. If the control group is properly identified, its propensity score distribution should be very similar to that of the treatment group. Table 7 shows that the propensity score difference between the two groups is very small. For example, in Panel A, the maximum difference in the propensity scores is 0.047 , while the $95^{\text {th }}$ percentile of the difference is only 0.010 . Second, we report the between-group mean differences in the bank characteristics used to estimate propensity scores and their corresponding $t$-statistics. If the matching is valid, the control and treatment banks should be alike in these post-matching characteristics. As reported in Table 7, none of them is significantly different in their means. In particular, there are no significant between-group differences in $\Delta$ Total compensation, $\Delta$ Equity compensation or $\Delta$ Cash compensation in Panel A, $\Delta$ Delta or $\Delta$ Vega in Panel B, which confirms that our matching satisfies the parallel trend assumption. Overall, the diagnostic test results justify the validity of our matching approach.

After obtaining the valid matched pairs, we compute DiD estimators for CEO pay and pay sensitivity surrounding megamergers. In Panel A of Table 7, for each CEO pay variable, the mean difference before (after) megamerger is computed by subtracting the mean CEO pay of the control group from that of the treatment group over the period before (after) the megamerger year. The $t$ statistics testing whether the mean difference is equal to 0 are reported in brackets. The mean DiD estimators are then calculated by subtracting the between-group mean difference before the megamerger year from that after the year. In column 3 of Panel A, total compensation and equity compensation both report positive and significant DiD estimators, while the DiD estimator on cash compensation is positive but insignificant. The results suggest that the increases in total compensation and equity compensation in the post-megamerger period relative to the pre-megamerger period in acquiring banks are of a significantly larger magnitude than those in matched non-acquiring banks, but the increase in cash compensation surrounding megamergers in acquiring banks does not significantly differ from that in 
matched control banks. The magnitude of the DiD estimator on total compensation can be interpreted that asset growth via megamergers, on average, increases CEO total compensation in acquiring banks by $\$ 624,000$ in the post-megamerger period relative to the pre-megamerger period in comparison to the contemporary CEO compensation change in matched non-acquiring banks. In Panel B of Table 7, we present $\mathrm{DiD}$ estimators for CEO pay sensitivity around megamergers. We document a negative and significant DiD estimator on delta, which suggests that CEO firm-related equity wealth in acquiring banks becomes less sensitive to stock price after megamergers relative to that in non-acquiring banks. Vega reports a statistically insignificant DiD estimator, consistent with our finding that merger growth does not significantly affect CEO risk-taking incentives.

\section{(iv) Robustness Checks}

\section{(a) Controlling for Other Acquirer Characteristics}

Other acquirer characteristics, such as growth opportunity (Guay, 1999), financial policy (Coles et al., 2006), ownership structure (Hartzell and Starks, 2003) and board monitoring (Chhaochharia and Grinstein, 2009), may influence CEO compensation. We thus include a set of additional control variables to mitigate the potential omitted variable bias related to these observed time-varying acquirer characteristics. Specifically, these controls include Market-to-book, Sales growth, Leverage, Cash holdings, Institutional ownership, Institutional ownership concentration, Board independence and Board size. After they are incorporated into the baseline model, our main findings continue to hold. For the additional control variables, we find that banks with large cash holdings pay their CEOs more. The concentration of institutional shareholdings significantly reduces bank CEO total compensation but increases bank CEO pay-performance sensitivity, which corroborates the argument of Hartzell and Starks (2003) that institutional investors play a monitoring role in executive pay-setting process.

\section{(b) Forms of CEO Compensation}

CEO equity compensation is awarded in the form of stock and stock options. CEO cash compensation contains salary and bonus. As in Coles et al. (2006), we compute CEO delta as the sum of stock delta and stock option delta, and use stock option vega as a proxy for CEO vega. We then examine the 
merger-pay relation by assessing the detailed CEO compensation and delta categories: stock compensation, stock option compensation, salary, bonus, stock delta and stock option delta. We find that merger growth significantly increases stock compensation and stock option compensation, but has no significant effect on salary or bonus. The effects of merger growth on stock delta and stock option delta are negative and marginally significant. These results generally support our main conclusions.

\section{(c) Alternative Samples}

Our results are robust to alternative merger samples: (1) the sample excluding mergers in which the acquirer's pre-merger holding of the shares outstanding of the target is more than $20 \%$, (2) alternative cut-off points of $30 \%$ and $40 \%$ regarding the acquirer's pre-merger holding of the shares outstanding of the target, and (3) excluding mergers in which the acquirer owns more than $90 \%$ of the shares outstanding of the target through a purchase of at least $50 \%$. As another robustness check, we require that the bank does not replace its CEO during the three years prior to the merger completion year and has at least three years of data over the entire sample period. The analyses repeated using the alternative samples report similar results.

\section{ADDITIONAL ANALYSES}

\section{(i) High-versus Low-Megamerger Banks}

We compare the merger-pay relation between high- and low-megamerger banks that are split by the median dollar value of banks' total megamerger transactions over the sample period. ${ }^{14}$ Intuitively, if an overall merger policy is set by boards of directors, CEOs who achieve this M\&A target should be better rewarded. The different M\&A goals of banks should generate some cross-sectional variation in the merger-pay links. In light of this, we rerun the baseline regressions for the two groups of banks. The results in Table 8 show that asset growth through megamergers significantly increases CEO total and

\footnotetext{
14 The results (untabulated) are qualitatively unchanged if the sample is split by the median frequency of
} megamergers made by banks over the sample period. 
equity compensation across the two groups. Given the same dollar amount of asset growth through megamergers, the increases in CEO total and equity compensation in high-megamerger banks are of a substantially lower magnitude than those in low-megamerger banks. Specifically, per $\$ 1$ million of assets acquired in megamergers, CEO total compensation increases by $\$ 1,978$ in low-megamerger banks but by only $\$ 170$ in high-megamerger banks. The results suggest that high-megamerger CEOs are discouraged from making too many M\&As and that boards of directors employ compensation arrangements as an instrument to restrain CEOs' excessive M\&A activity.

\section{$<<$ Insert Table 8 about here $>>$}

When turning to look at CEO incentives, we find that the significant decreasing effect of megamerger growth on CEO delta only exists in high-megamerger banks, even though CEOs in these banks do not gain as large an increase in compensation as CEOs in low-megamerger banks after M\&As. Megamerger growth significantly increases CEO vega in low-megamerger banks, which suggests that CEOs in these banks are given stronger incentives to employ risky investment opportunities. For control variables, we find that, compared to CEOs in low-megamerger banks, those in high-megamerger banks have their total and equity compensation tied less to firm-specific stock price changes and more to accounting returns. As most M\&As are accompanied by low stock returns, our results suggest that acquiring CEOs in high-megamerger banks tend to capture the boards to make their incentive pay more dependent on the relatively better-performing measure (i.e., accounting profit), in line with the finding of Morse et al. (2011).

\section{(ii) 'Top Five' Executive Compensation}

Bank CEOs may need the support of other top executives in getting their M\&A plans approved by boards of directors. By doing so, these non-CEO executives may also receive private benefits from the M\&A transactions. To warrant a closer investigation of the merger's effect on executive compensation, we examine how merger growth affects the pay and pay sensitivity of 'top five' executives. To be included in the analysis, a sample bank must have complete data on the pay and pay sensitivity of at least five top executives. If the data are available for more than five top executives, we restrict our analysis to the five executives with the highest total compensation. We control for the stock ownership 
of these executives. The untabulated regression results show that asset growth due to mergers is positively and significantly associated with the total and equity compensation of top five executives but are not significantly related to their cash compensation. Merger growth adds significantly more to executive compensation than does non-merger internal growth. For $\$ 1$ million of new assets acquired through megamergers, there is an increment of $\$ 686.6$ in the total compensation of top five executives; while \$1 million of internal asset growth increases top five executives' total compensation by only \$36.9. About $78 \%$ of the increment in the executives' total compensation due to megamerger growth comes in the form of equities. Nonetheless, we do not find that merger growth significantly affects the delta or vega of top five executives' equity portfolios. The above results continue to hold if CEOs are excluded from the top five executive pool. Overall, the results suggest that top five executives are better rewarded by agreeing with CEOs to make M\&As.

\section{(iii) Are Banks Different from Industrial Firms?}

We ask whether the same M\&A effects exist in industrial firms. In Table 9, we investigate the mergerpay relation in industrial firms. ${ }^{15}$ The results show that asset growth through mergers significantly increases CEO total and equity compensation in industrial firms, consistent with our results for banks. In contrast to bank CEOs, for whom we find no significant increases to their cash pay, we find that CEOs in industrial firms receive higher cash compensation following M\&As. Compared to banks, industrial firms face less stringent regulatory scrutiny, which could make the large post-merger cash rewards more feasible. In particular, the increases in CEO total and equity compensation due to mergers are of a smaller magnitude in industrial firms than in banks. For example, in column 1 of Table 9, the coefficient on Assets acquired in megamergers is 0.1297 , which is lower than the corresponding coefficient of 0.1875 in column 1 of Table 4 for banks. It means that every $\$ 1$ million of assets acquired via megamergers increases CEO total compensation by $\$ 57.8(129.7-187.5=-57.8)$ less in industrial firms than in banks. Furthermore, we show that CEO delta and vega in industrial firms are positively

\footnotetext{
${ }^{15} \mathrm{We}$ also examine non-bank financial firms. The untabulated regression results show that the effects of merger growth on CEO pay and pay sensitivity in non-bank financial firms are qualitatively similar to those documented in Table 9 for industrial firms.
} 
associated with merger growth. The results suggest that, although M\&As raise industrial firm CEOs' compensation, their incentives become more aligned with those of shareholders after M\&As, indicative of a less severe agency problem as a result of M\&As in industrial firms than in banks. Overall, the results suggest that the merger-pay relation is not completely identical across banks and industrial firms. $<<$ Insert Table 9 about here $>>$

In Table 10, we use a DiD estimator to delineate the relative impact of merger growth on CEO compensation between banks and industrial firms. First, we employ a one-to-one nearest neighbour PSM approach to match industrial firm megamergers to bank megamergers we analyse in Table 7 . We identify the industrial firm megamergers based on the following criteria: (1) the matched acquiring industrial firm has similar firm size to the acquiring bank in the year prior to megamerger completion; (2) the matched industrial firm megamerger has similar deal value to the bank megamerger; (3) the matched acquiring industrial firm has similar firm performance to the acquiring bank in the year prior to megamerger completion, so that the relative change in CEO compensation arrangements surrounding megamergers for the matched pairs does not result from their different performance; (4) the industrial firm has the same CEO over the five-year period centred on the megamerger completion year; and (5) the $\mathrm{CEO}$ in the matched industrial firm exhibits similar characteristics to the CEO in the treatment bank, which ensures that the disparity in pay is not driven by their different characteristics. To fulfil these criteria, we control for Total assets before megamergers, Assets acquired in megamergers, Growth above industry index, Return on assets, Female CEO, CEO duality, CEO age and CEO shareholding in the first-stage probit regression of PSM, where the dependent variable is equal to 1 if the megamerger observation is from a bank, and 0 if it is from an industrial firm. To satisfy the parallel trend assumption of the DiD estimator, the probit regression in Panel A of Table 10 additionally controls for $\Delta$ Total compensation, $\Delta$ Equity compensation and $\Delta$ Cash compensation over the three years prior to megamergers, while the probit regression in Panel B additionally controls for $\Delta$ Delta and $\Delta V e g a$.

$$
<<\text { Insert Table } 10 \text { about here }>>
$$

In Table 10, we report the propensity score distributions of acquiring banks and matched acquiring industrial firms. The two groups show similar propensity score distributions, and none of the post-matching between-group mean differences are statistically significant. These diagnostic tests 
assure us of the validity of the matching. We then calculate the DiD estimators. In column 3 of Panel A, the DiD estimator on total compensation is positive and significant, which suggests that bank CEOs, on average, receive a significantly larger increase in total compensation due to megamergers than industrial firm CEOs. Asset growth through an average megamerger increases bank CEO total compensation by $\$ 753,000$ in the post-megamerger period relative to the pre-megamerger period in comparison to the contemporary change in industrial firm CEO total compensation. The DiD estimator on equity compensation is significantly positive, while the DiD estimator on cash compensation is positive but insignificant. In Panel B, the DiD estimator on delta is significantly negative, which indicates that the sensitivity of bank CEOs' equity wealth to stock price materially declines following megamergers, relative to that of industrial firm CEOs. Vega reports an insignificant DiD estimator. Collectively, the results suggest that banks are different from industrial firms in terms of the mergerpay relation.

\section{(iv) Global Financial Crisis}

The GFC led to large failures in financial institutions. Globally, the seizure of credit became severe. Credit became impossibly costly, evidenced by the increased spread of deposit and loan rates, liquidation of equities and non-zero interest. Insecurity about asset value prompted capital hoarding, drying up liquidity and consequently declining demand and employment. Apparently, the GFC was in part attributed to the improper design of executive compensation that fuelled irresponsible corporate behaviour, such as bank bonuses that are excessively linked to investment risk taking (Bhagat and Bolton, 2014). As former FDIC chairman Sheila Bair stated, 'The crisis has shown that most financial institution compensation systems were not properly linked to risk management. Formula-driven compensation allows high short-term profits to be translated into generous bonus payments, without regard to any longer-term risks' (FDIC testimony, 14 January 2010). The GFC magnified the issues of bank remuneration and risk taking, and brought renewed scrutiny of executive compensation. In the wake of the crisis, the Obama administration passed the Dodd-Frank Wall Street Reform and Consumer Protection Act to improve financial transparency and executive accountability by curbing excessive pay and undue incentives in compensation arrangements awarded by financial institutions. It is worthwhile 
to study whether the economic shock of the GFC and the resultant changes in regulatory systems have had any effect on the merger-pay links.

In Table 11, we examine the effects of the GFC and post-crisis regulatory reform on the relation between bank megamergers and CEO compensation. The full sample is divided into three periods: the pre-GFC period from 1992 to 2007, the GFC in 2008, and the post-GFC period from 2009 to $2014 .{ }^{16}$ In Panel A, our main findings for the merger-pay relation generally hold before the crisis. During the crisis, the decreasing impact of megamerger growth on CEO equity compensation exceeds its increasing impact on the cash compensation, leading to a net decline in the total compensation. As noted, the G20 identified the improper link between risk management and executive compensation as one of the root causes of the GFC. The crisis might have simply revealed the prevailing problems that had long existed in bank remuneration systems. During the crisis, regulators could have more closely scrutinised CEOs' self-serving compensation arrangements especially around large capital events, such as M\&As, which could result in a negative merger-pay relation. In the post-crisis period, CEO pay is positively related to asset growth through megamergers, which suggests that M\&As serve as an instrument for bank CEOs to counter the intended effect of the post-crisis regulatory reform on their compensation.

\section{$<<$ Insert Table 11 about here $>>$}

The results for CEO incentives offer us mixed inferences on the effectiveness of the post-crisis regulatory reform. Megamerger growth has a negative effect on CEO delta during the GFC, indicating that M\&As can be used by bank CEOs to disconnect their wealth from the bank's stock price, which dropped severely in the crisis. After the GFC, this negative relation becomes statistically insignificant; however, a noticeable increase in $\mathrm{CEO}$ vega arises. It appears that government intervention to curb bank risk taking fails to discourage acquiring banks from providing their CEOs with risk-taking incentives to employ post-crisis new growth opportunities.

\footnotetext{
${ }^{16}$ To examine the effects of the GFC and post-crisis regulatory reform, the six-year period after the crisis (2009$2014)$ is compared to the six-year period before the GFC (2002-2007). We verify that the regression results for the whole pre-crisis period (1992-2007) are consistent with the results for the six-year period prior to the crisis (2002-2007) and that the results for 2002-2007 are qualitatively similar to those for another six-year control period 1996-2001. This confirms that our results are robust to different six-year control periods before the crisis.
} 
The GFC could have a more severe impact on banks than on industrial firms. We test whether the results differ across the two groups of firms. First, we identify a control sample of industrial firms using a one-to-one nearest neighbour PSM with replacement. The dependent variable in the first-stage probit regression is equal to 1 if the firm is from the banking industry, and 0 if it is from a non-financial industry. The independent variables in the probit regression include Total assets before megamergers, Assets acquired in megamergers, Growth above industry index, Return on assets, Female CEO, CEO duality, CEO age and CEO shareholding. After obtaining the propensity scores, we match each bankyear to its nearest-neighbour industrial-firm-year. We use the matched industrial firm control sample to study the effect of the GFC in comparable industrial firms. Panel B of Table 11 shows that the influences of the GFC and post-crisis regulatory reform are different for industrial firms in some respects. In 2008, the deterring effect of the GFC on CEO pay was absent in industrial firms. This could be because industrial firms were accorded less blame for causing the financial crisis and, therefore, their CEO compensation practices were less scrutinised by regulators during the crisis. Following the crisis, the positive relation between megamerger growth and CEO vega in industrial firms disappears, suggesting that industrial firm M\&A activity has no significant effect on CEOs' post-crisis risk-taking incentives.

\section{CONCLUSION}

CEOs may engage in firm-expansion activities to gain favourable compensation arrangements at the expense of shareholders. M\&As could be one of the key investment channels for CEOs to achieve this goal. This paper investigates the potential agency problems inferred from the links between CEO compensation and M\&As, and compares them with those arising from non-merger internal asset growth. We have several findings. First, CEO compensation is positively related to both merger growth and non-merger internal growth, with the latter being significantly smaller in magnitude. Second, CEO delta is negatively related to merger growth, indicating that M\&As are one way for CEOs to decouple their equity wealth from performance. Nonetheless, there is no significant relation between CEO vega and merger growth. Third, merger growth adds less to CEO compensation in high-megamerger banks than in low-megamerger banks, which suggests that bank boards discourage high merger activity through CEO compensation arrangements. Fourth, merger growth in banks increases the total compensation of 
'top five' executives. Fifth, as compared to mergers in industrial firms, bank mergers significantly increase CEO compensation but reduce CEO delta. Finally, the post-crisis regulatory reform of executive compensation in financial institutions has limited effectiveness in mitigating the merger-pay links in banks.

This paper clarifies the effects of bank mergers on various aspects of CEO compensation, complementing the previous literature that has largely focused on the level and composition of the compensation. This paper clarifies the unsettled merger-pay relation for CEOs in banks by differentiating the effects of the expansion attained in two different ways - namely, M\&As and internal asset growth. This paper compares bank mergers and industrial firm mergers, and shows that there are higher CEO compensation and lower CEO delta after bank mergers relative to matched industrial firm mergers, indicative of a more severe agency problem brought by bank mergers. Finally, this paper supplements the scarce research on executive compensation and the GFC. There are also policy implications. First, CEO rent seeking in compensation should be fully considered and disciplined in bank M\&A decision making. Second, the established regulations should be enforced or amended for the improvement of their effectiveness in restricting the merger-pay links in banks. Third, the monitoring role of bank boards in the CEO pay-setting process should be strengthened to protect minority shareholders' interests. 


\section{REFERENCES}

Adams, R. and H. Mehran (2003), 'Is Corporate Governance Different for Bank Holding Companies?', Economic Policy Review, Vol. 9, No. 1, pp. 123-42.

Agrawal, A., J. F. Jaffe and G. N. Mandelker (1992), 'The Post-Merger Performance of Acquiring Firms: A Re-Examination of an Anomaly', Journal of Finance, Vol. 47, No. 4, pp. 1605-21.

Amihud, Y. and B. Lev (1981), 'Risk Reduction as a Managerial Motive for Conglomerate Mergers', The Bell Journal of Economics, Vol. 12, No. 2, pp. 605-17.

Anderson, C. W., D. A. Becher and T. L. Campbell (2004), 'Bank Mergers, the Market for Bank CEOs, and Managerial Incentives', Journal of Financial Intermediation, Vol. 13, No. 1, pp. 6-27.

Arellano, M. and O. Bover (1995), 'Another Look at the Instrumental Variable Estimation of ErrorComponents Models', Journal of Econometrics, Vol. 68, No. 1, pp. 29-51.

Armstrong, C. S., J. L. Blouin, A. D. Jagolinzer and D. F. Larcker (2015), 'Corporate Governance, Incentives, and Tax Avoidance', Journal of Accounting and Economics, Vol. 60, No. 1, pp. 1-17. , D. F. Larcker, G. Ormazabal and D. J. Taylor (2013), 'The Relation Between Equity Incentives and Misreporting: The Role of Risk-Taking Incentives', Journal of Financial Economics, Vol. 109, No. 2, pp. 327-50.

Avery, C., J. A. Chevalier and S. Schaefer (1998), 'Why Do Managers Undertake Acquisitions? An Analysis of Internal and External Rewards for Acquisitiveness', Journal of Law, Economics, \& Organization, Vol. 14, No. 1, pp. 24-43.

Baker, G. P. and B. J. Hall (2004), 'CEO Incentives and Firm Size', Journal of Labor Economics, Vol. 22, No. 4, pp. 767-98.

, M. C. Jensen and K. J. Murphy (1988), 'Compensation and Incentives: Practice vs. Theory', Journal of Finance, Vol. 43, No. 3, pp. 593-616.

Barro, J. R. and R. J. Barro (1990), 'Pay, Performance, and Turnover of Bank CEOs', Journal of Labor Economics, Vol. 8, No. 4, pp. 448-81.

Barth, J. R., G. Caprio and R. Levine (2004), 'Bank Supervision and Regulation: What Works Best', Journal of Financial Intermediation, Vol. 13, No. 2, pp. 205-48.

Bebchuk, L. and Y. Grinstein (2005), 'Firm Expansion and CEO Pay', Working Paper (National Bureau of Economic Research).

and J. M. Fried (2003), 'Executive Compensation as an Agency Problem', Journal of Economic Perspectives, Vol. 17, No. 3, pp. 71-92.

— - and D. I. Walker (2002), 'Managerial Power and Rent Extraction in the Design of Executive Compensation', Working Paper (National Bureau of Economic Research).

- and H. Spamann (2010), 'Regulating Bankers' Pay', Georgetown Law Journal, Vol. 98, No. 2, pp. 247-87.

Belkhir, M. and A. Chazi (2010), 'Compensation Vega, Deregulation, and Risk-Taking: Lessons from the US Banking Industry', Journal of Business Finance \& Accounting, Vol. 37, Nos. 9\&10, pp. $1218-47$.

Bertrand, M. and S. Mullainathan (2001), 'Are CEOs Rewarded for Luck? The Ones without Principals are', The Quarterly Journal of Economics, Vol. 116, No. 3, pp. 901-32.

Bhagat, S. and B. Bolton (2014), 'Financial Crisis and Bank Executive Incentive Compensation', Journal of Corporate Finance, Vol. 25, pp. 313-41.

Black, B. S. (1989), 'Bidder Overpayment in Takeovers', Stanford Law Review, Vol. 41, No. 3, pp. 597-660.

Bliss, R. T. and R. J. Rosen (2001), 'CEO Compensation and Bank Mergers', Journal of Financial Economics, Vol. 61, No. 1, pp. 107-38. 
Bugeja, M., R. da Silva Rosa, L. Duong and H. Izan (2012a), 'CEO Compensation from M\&As in Australia', Journal of Business Finance \& Accounting, Vol. 39, Nos. 9\&10, pp. 1298-329.

— Z. P. Matolcsy and H. Spiropoulos (2012b), 'Is There a Gender Gap in CEO Compensation?', Journal of Corporate Finance, Vol. 18, No. 4, pp. 849-59.

Byrd, J. W. and K. A. Hickman (1992), 'Do Outside Directors Monitor Managers?: Evidence from Tender Offer Bids', Journal of Financial Economics, Vol. 32, No. 2, pp. 195-221.

Cai, J. and A. M. Vijh (2007), 'Incentive Effects of Stock and Option Holdings of Target and Acquirer CEOs', Journal of Finance, Vol. 62, No. 4, pp. 1891-933.

Chen, Y., C. Truong and M. Veeraraghavan (2015), 'CEO Risk-Taking Incentives and the Cost of Equity Capital', Journal of Business Finance \& Accounting, Vol. 42, Nos. 7\&8, pp. 915-46.

Cheng, Q. and T. D. Warfield (2005), 'Equity Incentives and Earnings Management', The Accounting Review, Vol. 80, No. 2, pp. 441-76.

Chhaochharia, V. and Y. Grinstein (2009), 'CEO Compensation and Board Structure', Journal of Finance, Vol. 64, No. 1, pp. 231-61.

Coles, J. L., N. D. Daniel and L. Naveen (2006), 'Managerial Incentives and Risk-Taking', Journal of Financial Economics, Vol. 79, No. 2, pp. 431-68.

Conyon, M. J. (2014), 'Executive Compensation and Board Governance in US Firms', The Economic Journal, Vol. 124, No. 574, pp. F60-F89.

- and P. Gregg (1994), 'Pay at the Top: A Study of the Sensitivity of Top Director Remuneration to Company Specific Shocks', National Institute Economic Review, Vol. 149, No. 1, pp. 83-92.

Core, J. and W. Guay (1999), 'The Use of Equity Grants to Manage Optimal Equity Incentive Levels', Journal of Accounting and Economics, Vol. 28, No. 2, pp. 151-84.

and - (2002), 'Estimating the Value of Employee Stock Option Portfolios and their Sensitivities to Price and Volatility', Journal of Accounting Research, Vol. 40, No. 3, pp. 613-30.

- R. W. Holthausen and D. F. Larcker (1999), 'Corporate Governance, Chief Executive Officer Compensation, and Firm Performance', Journal of Financial Economics, Vol. 51, No. 3, pp. 371406.

Croci, E. and D. Petmezas (2015), 'Do Risk-Taking Incentives Induce CEOs to Invest? Evidence from Acquisitions', Journal of Corporate Finance, Vol. 32, pp. 1-23.

Cuñat, V. and M. Guadalupe (2009), 'Executive Compensation and Competition in the Banking and Financial Sectors', Journal of Banking \& Finance, Vol. 33, No. 3, pp. 495-504.

Cyert, R. M., S.-H. Kang and P. Kumar (2002), 'Corporate Governance, Takeovers, and TopManagement Compensation: Theory and Evidence', Management Science, Vol. 48, No. 4, pp. 453-69.

Datta, S., M. Iskandar-Datta and K. Raman (2001), 'Executive Compensation and Corporate Acquisition Decisions', Journal of Finance, Vol. 56, No. 6, pp. 2299-336.

DeYoung, R., E. Y. Peng and M. Yan (2013), 'Executive Compensation and Business Policy Choices at US Commercial Banks', Journal of Financial and Quantitative Analysis, Vol. 48, No. 1, pp. 165-96.

Fahlenbrach, R. and R. M. Stulz (2011), 'Bank CEO Incentives and the Credit Crisis', Journal of Financial Economics, Vol. 99, No. 1, pp. 11-26.

Fuller, K., J. Netter and M. Stegemoller (2002), 'What Do Returns to Acquiring Firms Tell Us? Evidence from Firms that Make Many Acquisitions', Journal of Finance, Vol. 57, No. 4, pp. $1763-$ 93.

Gormley, T. A., D. A. Matsa and T. Milbourn (2013), 'CEO Compensation and Corporate Risk: Evidence from a Natural Experiment', Journal of Accounting and Economics, Vol. 56, No. 2, pp. $79-101$. 
Grinstein, Y. and P. Hribar (2004), 'CEO Compensation and Incentives: Evidence from M\&A Bonuses', Journal of Financial Economics, Vol. 73, No. 1, pp. 119-43.

Guay, W. R. (1999), 'The Sensitivity of CEO Wealth to Equity Risk: An Analysis of the Magnitude and Determinants', Journal of Financial Economics, Vol. 53, No. 1, pp. 43-71.

Hagendorff, J. and F. Vallascas (2011), 'CEO Pay Incentives and Risk-Taking: Evidence from Bank Acquisitions', Journal of Corporate Finance, Vol. 17, No. 4, pp. 1078-95.

Hall, B. J. and J. B. Liebman (1998), 'Are CEOs Really Paid Like Bureaucrats?' The Quarterly Journal of Economics, Vol. 113, No. 3, pp. 653-91.

Harford, J. and K. Li (2007), 'Decoupling CEO Wealth and Firm Performance: The Case of Acquiring CEOs', Journal of Finance, Vol. 62, No. 2, pp. 917-49.

Hartzell, J. C. and L. T. Starks (2003), 'Institutional Investors and Executive Compensation', Journal of Finance, Vol. 58, No. 6, pp. 2351-74.

Hope, O.-K. and W. B. Thomas (2008), 'Managerial Empire Building and Firm Disclosure', Journal of Accounting Research, Vol. 46, No. 3, pp. 591-626.

Hsu, A. W. H. and C. H. Liao (2012), 'Do Compensation Committees Pay Attention to Section 404 Opinions of the Sarbanes-Oxley Act?', Journal of Business Finance \& Accounting, Vol. 39, Nos. 9\&10, pp. 1240-71.

Hubbard, R. G. and D. Palia (1995), 'Executive Pay and Performance Evidence from the U.S. Banking Industry', Journal of Financial Economics, Vol. 39, No. 1, pp. 105-30.

Jensen, M. C. (1986), 'Agency Costs of Free Cash Flow, Corporate Finance, and Takeovers', American Economic Review, Vol. 76, No. 2, pp. 323-29.

- and K. J. Murphy (1990), 'Performance Pay and Top-Management Incentives', Journal of Political Economy, Vol. 98, No. 2, pp. 225-64.

John, K., H. Mehran and Y. Qian (2010), 'Outside Monitoring and CEO Compensation in the Banking Industry', Journal of Corporate Finance, Vol. 16, No. 4, pp. 383-99.

Khorana, A. and M. Zenner (1998), 'Executive Compensation of Large Acquirors in the 1980s', Journal of Corporate Finance, Vol. 4, No. 3, pp. 209-40.

Lambert, R. A. and D. F. Larcker (1988), 'Executive Compensation Effects of Large Corporate Acquisitions', Journal of Accounting and Public Policy, Vol. 6, No. 4, pp. 231-43.

Levi, M., K. Li and F. Zhang (2010), 'Deal or No Deal: Hormones and the Mergers and Acquisitions Game', Management Science, Vol. 56, No. 9, pp. 1462-83.

Lord, R. A. and Y. Saito (2012), 'Does Compensation Structure Alleviate Personal CEO Risks?', Journal of Business Finance \& Accounting, Vol. 39, Nos. 9\&10, pp. 1272-97.

Loughran, T. and A. M. Vijh (1997), 'Do Long-Term Shareholders Benefit from Corporate Acquisitions?', Journal of Finance, Vol. 52, No. 5, pp. 1765-90.

Magnan, M. L. and S. St-Onge (1997), 'Bank Performance and Executive Compensation: A Managerial Discretion Perspective', Strategic Management Journal, Vol. 18, No. 7, pp. 573-81.

Masulis, R. W., C. Wang and F. Xie (2007), 'Corporate Governance and Acquirer Returns', Journal of Finance, Vol. 62, No. 4, pp. 1851-89.

Mehran, H. (1995), 'Executive Compensation Structure, Ownership, and Firm Performance', Journal of Financial Economics, Vol. 38, No. 2, pp. 163-84.

Minnick, K., H. Unal and L. Yang (2011), 'Pay for Performance? CEO Compensation and Acquirer Returns in BHCs', Review of Financial Studies, Vol. 24, No. 2, pp. 439-72.

Mishra, C. S. and J. F. Nielsen (2000), 'Board Independence and Compensation Policies in Large Bank Holding Companies', Financial Management, Vol. 29, No. 3, pp. 51-69.

Moeller, S. B., F. P. Schlingemann and R. M. Stulz (2004), 'Firm Size and the Gains from Acquisitions', Journal of Financial Economics, Vol. 73, No. 2, pp. 201-28. 
and - (2005), 'Wealth Destruction on a Massive Scale? A Study of AcquiringFirm Returns in the Recent Merger Wave', Journal of Finance, Vol. 60, No. 2, pp. 757-82.

Morse, A., V. Nanda and A. Seru (2011), 'Are Incentive Contracts Rigged by Powerful CEOs?', Journal of Finance, Vol. 66, No. 5, pp. 1779-821.

Murphy, K. J. (1985), 'Corporate Performance and Managerial Remuneration: An Empirical Analysis', Journal of Accounting and Economics, Vol. 7, No. 1, pp. 11-42.

_ (1999), 'Executive Compensation', Handbook of Labor Economics, Vol. 3, pp. 2485-563. - and T. Sandino (2010), 'Executive Pay and "Independent" Compensation Consultants', Journal of Accounting and Economics, Vol. 49, No. 3, pp. 247-62.

Rau, P. R. and T. Vermaelen (1998), 'Glamour, Value and the Post-Acquisition Performance of Acquiring Firms', Journal of Financial Economics, Vol. 49, No. 2, pp. 223-53.

Ravenscraft, D. J. and F. M. Scherer (2011), Mergers, Sell-Offs, and Economic Efficiency (Washington, D.C.: Brookings Institution Press).

Schaefer, S. (1998), 'The Dependence of Pay-Performance Sensitivity on the Size of the Firm', Review of Economics and Statistics, Vol. 80, No. 3, pp. 436-43.

Seo, J., D. L. Gamache, C. E. Devers and M. A. Carpenter (2015), 'The Role of CEO Relative Standing in Acquisition Behavior and CEO Pay', Strategic Management Journal, Vol. 36, No. 12, pp. 187794.

Shivdasani, A. (1993), 'Board Composition, Ownership Structure, and Hostile Takeovers', Journal of Accounting and Economics, Vol. 16, No. 1, pp. 167-98.

— and D. Yermack (1999), 'CEO Involvement in the Selection of New Board Members: An Empirical Analysis', Journal of Finance, Vol. 54, No. 5, pp. 1829-53.

Smith, C. W. and R. M. Stulz (1985), 'The Determinants of Firms' Hedging Policies', Journal of Financial and Quantitative Analysis, Vol. 20, No. 4, pp. 391-405.

Thanassoulis, J. (2014), 'Bank Pay Caps, Bank Risk, and Macroprudential Regulation', Journal of Banking \& Finance, Vol. 48, pp. 139-51.

Trautwein, F. (1990), 'Merger Motives and Merger Prescriptions', Strategic Management Journal, Vol. 11, No. 4, pp. 283-95.

Williams, M. A. and R. P. Rao (2006), 'CEO Stock Options and Equity Risk Incentives', Journal of Business Finance \& Accounting, Vol. 33, Nos. 1\&2, pp. 26-44.

Windmeijer, F. (2005), 'A Finite Sample Correction for the Variance of Linear Efficient Two-Step GMM Estimators', Journal of Econometrics, Vol. 126, No. 1, pp. 25-51.

Wintoki, M. B., J. S. Linck and J. M. Netter (2012), 'Endogeneity and the Dynamics of Internal Corporate Governance', Journal of Financial Economics, Vol. 105, No. 3, pp. 581-606.

Yim, S. (2013), 'The Acquisitiveness of Youth: CEO Age and Acquisition Behavior', Journal of Financial Economics, Vol. 108, No. 1, pp. 250-73. 


\section{APPENDIX: VARIABLE DEFINITIONS}

\begin{tabular}{|c|c|}
\hline Variable & Definition \\
\hline \multicolumn{2}{|l|}{ CEO pay: } \\
\hline Total compensation & $\begin{array}{l}\text { The sum of salary, bonus, value of stock grants, Black-Scholes value of stock option grants, } \\
\text { other annual compensation (e.g., perquisites and other personal benefits), long-term incentive } \\
\text { payments and all other compensation (e.g., debt forgiveness and life insurance premiums). } \\
\text { Source: Execucomp }\end{array}$ \\
\hline Equity compensation & The value of stock and stock option grants. Source: Execucomp \\
\hline Cash compensation & Salary plus bonus. Source: Execucomp \\
\hline \multicolumn{2}{|l|}{ CEO pay sensitivity: } \\
\hline Delta & $\begin{array}{l}\text { The dollar change in the value of the CEO's stock and option portfolio given a } 1 \% \text { change in } \\
\text { the stock price. Source: Execucomp }\end{array}$ \\
\hline Vega & $\begin{array}{l}\text { The dollar change in the value of the CEO's stock option portfolio given a } 0.01 \text { change in the } \\
\text { standard deviation of stock returns. Source: Execucomp }\end{array}$ \\
\hline \multicolumn{2}{|l|}{ Asset growth: } \\
\hline Total assets & The book value of total assets. Source: Compustat \\
\hline $\begin{array}{l}\text { Assets acquired in } \\
\text { megamergers }\end{array}$ & $\begin{array}{l}\text { The dollar value of total assets acquired in megamergers over the prior three years. Source: } \\
\text { SDC }\end{array}$ \\
\hline Non-megamerger growth & The dollar value of non-megamerger internal asset growth over the prior three years. \\
\hline $\begin{array}{l}\text { Assets acquired in all } \\
\text { mergers }\end{array}$ & $\begin{array}{l}\text { The dollar value of total assets acquired in all mergers over the prior three years. Source: } \\
\text { SDC }\end{array}$ \\
\hline Non-merger growth & The dollar value of non-merger internal asset growth over the prior three years. \\
\hline \multicolumn{2}{|l|}{ CEO characteristics: } \\
\hline Female CEO & A dummy variable equal to 1 if the CEO is female, and 0 otherwise. Source: Execucomp \\
\hline CEO duality & $\begin{array}{l}\text { A dummy variable equal to } 1 \text { if the CEO serves as board chair, and } 0 \text { otherwise. Source: } \\
\text { Execucomp }\end{array}$ \\
\hline CEO age & The age of the CEO. Source: Execucomp \\
\hline CEO shareholding & The shares held by the CEO as a percentage of total shares outstanding. Source: Execucomp \\
\hline \multicolumn{2}{|l|}{ Financial characteristics: } \\
\hline $\begin{array}{l}\text { Change in firm value due } \\
\text { to change in industry } \\
\text { index }\end{array}$ & $\begin{array}{l}\text { The dollar change in the firm's equity value over the prior three years, given the percentage } \\
\text { change set equal to the value-weighted banking industry index return. Source: Compustat }\end{array}$ \\
\hline $\begin{array}{l}\text { Change in firm value due } \\
\text { to idiosyncratic change }\end{array}$ & $\begin{array}{l}\text { The total dollar change in the firm's equity value over the prior three years minus the dollar } \\
\text { change in equity value due to industry-wide stock price change. Source: Compustat }\end{array}$ \\
\hline Return on assets & Earnings before interest and taxes, divided by total assets. Source: Compustat \\
\hline Market-to-book & The ratio of market value to book value of equity. Source: Compustat \\
\hline Leverage & Total debt divided by total assets. Source: Compustat \\
\hline Sales growth & $\begin{array}{l}\text { The natural logarithm of } 1 \text { plus the ratio of sales in the current year to sales in the previous } \\
\text { year. Source: Compustat }\end{array}$ \\
\hline Cash holdings & Cash and short-term investments, divided by total assets. Source: Compustat \\
\hline $\begin{array}{l}\text { Total assets before } \\
\text { megamergers }\end{array}$ & $\begin{array}{l}\text { The book value of total assets in the year prior to megamerger completion year. Source: } \\
\text { Compustat }\end{array}$ \\
\hline $\begin{array}{l}\text { Growth above industry } \\
\text { index }\end{array}$ & $\begin{array}{l}\text { The stock return minus the industry index return, where industry is identified using the } \\
\text { Fama-French } 48 \text { industry classification. Source: CRSP }\end{array}$ \\
\hline \multicolumn{2}{|l|}{ Corporate governance: } \\
\hline Institutional ownership & $\begin{array}{l}\text { The shares held by institutional investors as a percentage of total shares outstanding. Source: } \\
\text { Thomson Reuters Institutional (13f) Holdings database }\end{array}$ \\
\hline $\begin{array}{l}\text { Institutional ownership } \\
\text { concentration }\end{array}$ & $\begin{array}{l}\text { The Herfindahl-Hirschman index of institutional ownership. Source: Thomson Reuters } \\
\text { Institutional (13f) Holdings database }\end{array}$ \\
\hline Board independence & The proportion of independent directors on the board. Source: RiskMetrics \\
\hline Board size & The number of directors on the board. Source: RiskMetrics \\
\hline
\end{tabular}


Table 1

Distribution of Bank Mergers

\begin{tabular}{|c|c|c|c|c|c|c|}
\hline \multicolumn{7}{|c|}{ Panel A: Megamerger distribution by year } \\
\hline \multirow[t]{2}{*}{ Year } & \multirow{2}{*}{$\begin{array}{l}\text { Number of } \\
\text { megamergers }\end{array}$} & \multirow{2}{*}{$\begin{array}{c}\text { Total } \\
\text { transaction value } \\
\text { (\$ billions) }\end{array}$} & \multirow{2}{*}{$\begin{array}{c}\text { Average } \\
\text { transaction value } \\
\text { (\$ billions) }\end{array}$} & \multirow{2}{*}{$\begin{array}{l}\text { Average ratio of transaction } \\
\text { value to acquirer's market } \\
\text { capitalisation }(\%)\end{array}$} & \multicolumn{2}{|c|}{$\begin{array}{l}\text { Average stock market reaction to } \\
\text { megamerger announcements (\%) }\end{array}$} \\
\hline & & & & & CAR $[2,+2]$ & CAR $[2,+250]$ \\
\hline 1992 & 2 & 1.74 & 0.87 & 55.02 & 0.75 & -18.89 \\
\hline 1993 & 8 & 6.70 & 0.84 & 30.73 & -1.52 & -28.30 \\
\hline 1994 & 5 & 2.88 & 0.58 & 32.42 & -5.14 & -31.56 \\
\hline 1995 & 13 & 1.69 & 0.13 & 20.65 & -0.55 & -4.45 \\
\hline 1996 & 17 & 30.07 & 1.77 & 36.89 & -0.25 & 11.18 \\
\hline 1997 & 26 & 45.50 & 1.75 & 36.93 & -2.27 & 1.94 \\
\hline 1998 & 34 & 206.35 & 6.07 & 41.97 & -3.63 & -36.32 \\
\hline 1999 & 11 & 5.18 & 0.47 & 23.53 & -5.09 & -22.81 \\
\hline 2000 & 19 & 71.16 & 3.75 & 29.55 & -2.27 & 31.36 \\
\hline 2001 & 17 & 29.16 & 1.72 & 26.36 & -1.75 & 9.36 \\
\hline 2002 & 5 & 5.78 & 1.16 & 25.66 & 0.54 & -31.37 \\
\hline 2003 & 8 & 9.77 & 1.22 & 23.98 & -1.84 & -10.77 \\
\hline 2004 & 24 & 136.03 & 5.67 & 33.64 & -2.67 & -1.95 \\
\hline 2005 & 11 & 10.50 & 0.95 & 20.37 & -0.83 & -9.47 \\
\hline 2006 & 18 & 53.04 & 2.95 & 26.13 & -1.70 & -8.37 \\
\hline 2007 & 10 & 15.67 & 1.57 & 29.78 & -1.00 & -1.23 \\
\hline 2008 & 10 & 22.38 & 2.24 & 23.20 & 0.64 & 33.27 \\
\hline 2009 & 1 & 0.54 & 0.54 & 64.81 & 41.70 & 109.12 \\
\hline 2010 & 2 & 0.96 & 0.48 & 13.35 & 5.48 & -16.21 \\
\hline 2011 & 8 & 4.88 & 0.61 & 42.84 & -3.53 & 0.06 \\
\hline 2012 & 8 & 16.32 & 2.04 & 22.66 & 0.49 & 20.86 \\
\hline 2013 & 7 & 2.68 & 0.38 & 41.47 & 0.02 & 7.67 \\
\hline 2014 & 7 & 3.46 & 0.49 & 34.59 & -1.85 & -6.68 \\
\hline All years & 271 & 682.45 & 2.52 & 31.62 & -1.71 & -3.41 \\
\hline \multicolumn{7}{|c|}{ Panel B: Merger distribution by year } \\
\hline \multirow[t]{2}{*}{ Year } & \multirow{2}{*}{$\begin{array}{l}\text { Number of } \\
\text { mergers }\end{array}$} & \multirow{2}{*}{$\begin{array}{c}\text { Total } \\
\text { transaction value } \\
\text { (\$ billions }) \\
\end{array}$} & \multirow{2}{*}{$\begin{array}{c}\text { Average } \\
\text { transaction value } \\
(\$ \text { billions }) \\
\end{array}$} & \multirow{2}{*}{$\begin{array}{l}\text { Average ratio of transaction } \\
\text { value to acquirer's market } \\
\text { capitalisation }(\%)\end{array}$} & \multicolumn{2}{|c|}{$\begin{array}{l}\text { Average stock market reaction to } \\
\text { merger announcements }(\%)\end{array}$} \\
\hline & & & & & CAR $[2,+2]$ & CAR $[2,+250]$ \\
\hline 1992 & 11 & 2.48 & 0.23 & 12.01 & -1.45 & -28.25 \\
\hline 1993 & 38 & 9.83 & 0.26 & 8.68 & -0.36 & -22.30 \\
\hline 1994 & 35 & 5.52 & 0.16 & 6.60 & -0.70 & -6.51 \\
\hline 1995 & 49 & 5.14 & 0.10 & 7.08 & -0.17 & 0.13 \\
\hline 1996 & 70 & 36.48 & 0.52 & 10.94 & -0.13 & 9.48 \\
\hline 1997 & 73 & 51.14 & 0.70 & 15.37 & -0.75 & 6.97 \\
\hline 1998 & 117 & 221.93 & 1.90 & 14.41 & -1.70 & -33.68 \\
\hline 1999 & 76 & 18.15 & 0.24 & 5.80 & -2.06 & -28.35 \\
\hline 2000 & 55 & 81.26 & 1.48 & 11.69 & -0.97 & 40.22 \\
\hline 2001 & 58 & 41.71 & 0.72 & 9.90 & -0.55 & -2.69 \\
\hline 2002 & 47 & 22.25 & 0.47 & 5.32 & -0.91 & -21.57 \\
\hline 2003 & 35 & 20.61 & 0.59 & 7.50 & -0.41 & -11.50 \\
\hline 2004 & 60 & 143.37 & 2.39 & 15.52 & -1.31 & -4.23 \\
\hline 2005 & 44 & 16.10 & 0.37 & 7.92 & -0.93 & -9.68 \\
\hline 2006 & 55 & 66.07 & 1.20 & 11.33 & -0.84 & -6.12 \\
\hline 2007 & 46 & 58.37 & 1.27 & 8.96 & -0.93 & -18.08 \\
\hline 2008 & 22 & 31.84 & 1.45 & 12.84 & 0.46 & 22.09 \\
\hline 2009 & 9 & 6.99 & 0.78 & 10.34 & 9.18 & -44.64 \\
\hline 2010 & 9 & 3.84 & 0.43 & 4.79 & -0.99 & -4.88 \\
\hline 2011 & 14 & 6.45 & 0.46 & 26.37 & -2.36 & 7.22 \\
\hline 2012 & 27 & 17.87 & 0.66 & 9.03 & 0.22 & 1.70 \\
\hline 2013 & 23 & 3.48 & 0.15 & 15.25 & 0.77 & 1.68 \\
\hline 2014 & 23 & 5.11 & 0.22 & 13.88 & -0.69 & -9.45 \\
\hline All years & 996 & 876.01 & 0.88 & 10.85 & -0.78 & -7.51 \\
\hline
\end{tabular}

This table presents bank merger distribution and deal characteristics by merger completion year. Panel A reports the statistics of megamergers, whose transaction value is no less than $10 \%$ of the market capitalisation of the acquiring bank measured 20 trading days prior to the merger announcement date. Panel B reports the statistics of all bank mergers. The average stock market reaction to merger announcements is assessed by the CARs over two different periods from day -2 to +2 and from -2 to +250 (in trading days), where day 0 is the merger announcement date. The expected return used to compute the CAR comes from a market model with the CRSP value-weighted index return as the market return over an estimation window $[-250,-20]$. 
Table 2

Descriptive Statistics of Sample Banks

\begin{tabular}{|c|c|c|c|c|c|c|c|c|c|c|}
\hline \multicolumn{11}{|c|}{ Panel A: Summary statistics } \\
\hline \multicolumn{3}{|c|}{ Variable } & $\mathrm{N}$ & Mean & SD & P1 & $\mathrm{P} 25$ & Median & P75 & P99 \\
\hline \multicolumn{11}{|l|}{ CEO pay: } \\
\hline \multicolumn{3}{|c|}{ Total compensation (\$ millions) } & 1753 & 4.046 & 5.328 & 0.381 & 1.199 & 2.214 & 4.585 & 23.260 \\
\hline \multicolumn{3}{|c|}{ Equity compensation ( $\$$ millions) } & 1753 & 2.119 & 4.175 & 0.000 & 0.117 & 0.735 & 2.280 & 17.000 \\
\hline \multicolumn{3}{|c|}{ Cash compensation ( $\$$ millions) } & 1753 & 1.273 & 1.332 & 0.279 & 0.650 & 0.907 & 1.324 & 7.975 \\
\hline \multicolumn{11}{|c|}{ CEO pay sensitivity: } \\
\hline \multicolumn{3}{|c|}{ Delta (\$ millions) } & 1720 & 0.507 & 1.015 & 0.003 & 0.066 & 0.195 & 0.510 & 4.410 \\
\hline \multicolumn{3}{|c|}{ Vega (\$ millions) } & 1718 & 0.126 & 0.228 & 0.000 & 0.010 & 0.036 & 0.124 & 1.232 \\
\hline \multicolumn{11}{|c|}{ Asset growth: } \\
\hline \multicolumn{3}{|c|}{ Total assets at $t-3$ ( $\$$ billions) } & 1753 & 50.925 & 193.008 & 0.567 & 4.154 & 8.853 & 26.078 & 1198.942 \\
\hline \multicolumn{3}{|c|}{ Assets acquired in megamergers ( $\$$ billions) } & 1753 & 1.026 & 5.699 & 0.000 & 0.000 & 0.000 & 0.108 & 32.790 \\
\hline \multicolumn{3}{|c|}{ Non-megamerger growth ( $\$$ billions) } & 1753 & 16.680 & 69.010 & -9.741 & 0.627 & 2.163 & 7.317 & 373.300 \\
\hline \multicolumn{3}{|c|}{ Assets acquired in all mergers ( $\$$ billions) } & 1753 & 1.283 & 6.211 & 0.000 & 0.000 & 0.033 & 0.352 & 32.790 \\
\hline Non-merg & growth $(\$$ billic & ns) & 1753 & 16.430 & 68.280 & -9.741 & 0.605 & 2.138 & 7.086 & 373.300 \\
\hline CEO cha & cteristics: & & & & & & & & & \\
\hline$\overline{\text { Female C }}$ & & & 1753 & 0.025 & 0.156 & 0.000 & 0.000 & 0.000 & 0.000 & 1.000 \\
\hline CEO dual & & & 1753 & 0.637 & 0.481 & 0.000 & 0.000 & 1.000 & 1.000 & 1.000 \\
\hline CEO age & & & 1753 & 57.200 & 6.808 & 40.000 & 53.000 & 57.000 & 62.000 & 76.000 \\
\hline CEO shar & olding & & 1753 & 0.012 & 0.029 & 0.000 & 0.001 & 0.004 & 0.011 & 0.147 \\
\hline Financial & haracteristics: & & & & & & & & & \\
\hline $\begin{array}{l}\text { Change in } \\
\text { industry it }\end{array}$ & $\begin{array}{l}\text { irm value due to } \\
\text { ex (\$ billions) }\end{array}$ & change in & 1753 & 1.556 & 7.294 & -15.660 & -0.074 & 0.286 & 1.278 & 30.950 \\
\hline $\begin{array}{l}\text { Change in } \\
\text { change (\$ }\end{array}$ & $\begin{array}{l}\text { irm value due to } \\
\text { illions) }\end{array}$ & idiosyncratic & 1753 & 0.637 & 6.216 & -19.120 & -0.353 & 0.122 & 0.686 & 34.370 \\
\hline Return on & ssets & & 1753 & 0.025 & 0.027 & -0.022 & 0.018 & 0.023 & 0.028 & 0.157 \\
\hline Market-to & ook & & 1753 & 1.963 & 1.564 & 0.209 & 1.195 & 1.668 & 2.351 & 7.549 \\
\hline Leverage & & & 1743 & 0.177 & 0.104 & 0.016 & 0.096 & 0.165 & 0.242 & 0.475 \\
\hline Sales grov & & & 1751 & 0.730 & 0.095 & 0.543 & 0.673 & 0.717 & 0.769 & 1.077 \\
\hline Cash hold & & & 1753 & 0.068 & 0.087 & 0.005 & 0.025 & 0.041 & 0.072 & 0.493 \\
\hline Corporate & overnance: & & & & & & & & & \\
\hline Institution & lownership & & 1560 & 0.557 & 0.189 & 0.154 & 0.420 & 0.561 & 0.688 & 1.000 \\
\hline Institution & l ownership con & entration & 1560 & 0.058 & 0.052 & 0.019 & 0.034 & 0.045 & 0.063 & 0.245 \\
\hline Board ind & pendence & & 1332 & 0.745 & 0.130 & 0.364 & 0.667 & 0.769 & 0.846 & 0.929 \\
\hline Board siz & & & 1332 & 12.730 & 3.245 & 7.000 & 10.000 & 12.000 & 15.000 & 19.000 \\
\hline Panel B & EO pay and pa & sensitivity by & & & & & & & & \\
\hline Year & $\begin{array}{c}\text { Total } \\
\text { compensation } \\
(\$ \text { millions })\end{array}$ & $\begin{array}{c}\text { Equity } \\
\text { compensation } \\
(\$ \text { millions })\end{array}$ & $\begin{array}{c}\text { Cash } \\
\text { compensation } \\
\text { (\$ millions) }\end{array}$ & $\begin{array}{r}\mathrm{Ra} \\
\text { con } \\
\text { total } \\
\end{array}$ & $\begin{array}{l}\text { io of equity } \\
\text { pensation to } \\
\text { compensation }\end{array}$ & $\begin{array}{r}\mathrm{R} \\
\text { con } \\
\text { total } \\
\end{array}$ & $\begin{array}{l}\text { tio of cash } \\
\text { pensation to } \\
\text { compensation }\end{array}$ & & $\begin{array}{l}\text { lta } \\
\text { llions) }\end{array}$ & $\begin{array}{c}\text { Vega } \\
\text { (\$ millions) }\end{array}$ \\
\hline 1992 & 2.272 & 0.942 & 1.084 & & 0.415 & & 0.477 & & 118 & 0.042 \\
\hline 1993 & 2.204 & 0.459 & 1.307 & & 0.180 & & 0.643 & & 240 & 0.034 \\
\hline 1994 & 2.598 & 1.207 & 1.147 & & 0.338 & & 0.567 & & 226 & 0.035 \\
\hline 1995 & 2.172 & 0.547 & 1.329 & & 0.224 & & 0.660 & & 379 & 0.040 \\
\hline 1996 & 3.233 & 1.203 & 1.530 & & 0.317 & & 0.557 & & 456 & 0.041 \\
\hline 1997 & 3.908 & 1.931 & 1.554 & & 0.363 & & 0.527 & & 653 & 0.032 \\
\hline 1998 & 4.549 & 2.457 & 1.581 & & 0.435 & & 0.460 & & 652 & 0.079 \\
\hline 1999 & 5.799 & 3.967 & 1.552 & & 0.464 & & 0.463 & & 528 & 0.113 \\
\hline 2000 & 5.942 & 3.806 & 1.634 & & 0.423 & & 0.492 & & 905 & 0.135 \\
\hline 2001 & 5.236 & 3.083 & 1.723 & & 0.478 & & 0.452 & & 303 & 0.185 \\
\hline 2002 & 4.754 & 2.721 & 1.673 & & 0.432 & & 0.495 & & 700 & 0.219 \\
\hline 2003 & 4.710 & 2.527 & 1.919 & & 0.403 & & 0.526 & & 378 & 0.245 \\
\hline 2004 & 4.666 & 2.147 & 1.963 & & 0.346 & & 0.542 & & 17 & 0.221 \\
\hline 2005 & 4.527 & 2.096 & 1.876 & & 0.330 & & 0.570 & & 817 & 0.211 \\
\hline 2006 & 5.026 & 2.562 & 1.011 & & 0.312 & & 0.416 & & 640 & 0.173 \\
\hline 2007 & 3.749 & 2.081 & 0.975 & & 0.324 & & 0.456 & & 436 & 0.132 \\
\hline 2008 & 2.977 & 1.670 & 0.724 & & 0.328 & & 0.471 & & 246 & 0.092 \\
\hline 2009 & 2.515 & 1.285 & 0.824 & & 0.277 & & 0.552 & & 215 & 0.082 \\
\hline 2010 & 3.217 & 1.429 & 1.056 & & 0.261 & & 0.537 & & 263 & 0.103 \\
\hline 2011 & 3.507 & 1.749 & 0.963 & & 0.324 & & 0.447 & & 222 & 0.091 \\
\hline 2012 & 3.580 & 1.707 & 0.959 & & 0.316 & & 0.431 & & 255 & 0.096 \\
\hline 2013 & 3.913 & 1.955 & 0.904 & & 0.355 & & 0.375 & & 368 & 0.091 \\
\hline 2014 & 4.175 & 2.119 & 1.012 & & 0.367 & & 0.364 & & 418 & 0.083 \\
\hline All years & 4.046 & 2.119 & 1.273 & & 0.349 & & 0.482 & & 507 & 0.126 \\
\hline
\end{tabular}

Notes:

This table presents descriptive statistics of 184 sample banks for the period 1992-2014. Panel A reports the statistics of the firm-year sample. Panel B reports the average pay and pay sensitivity of bank CEOs by sample year. See the appendix for variable definitions. 
Table 3

Determinants of Bank Merger Announcements

\begin{tabular}{|c|c|c|c|c|c|c|c|c|c|c|}
\hline \multirow[t]{3}{*}{$\overline{\mathrm{DV}}=$} & \multicolumn{10}{|c|}{ Megamerger announcement } \\
\hline & \multicolumn{5}{|c|}{ Panel A: Probit } & \multicolumn{5}{|c|}{ Panel B: Firm-fixed effects } \\
\hline & [1] & [2] & [3] & [4] & [5] & [6] & [7] & [8] & [9] & {$[10]$} \\
\hline \multirow[t]{2}{*}{ Return on assets } & 2.1952 & 2.4085 & 2.4357 & 1.7250 & 1.7959 & 0.9912 & 1.0563 & 1.0166 & 0.8437 & 0.8763 \\
\hline & [1.04] & [1.12] & [1.19] & {$[0.80]$} & {$[0.83]$} & [0.94] & {$[1.00]$} & {$[0.98]$} & {$[0.79]$} & {$[0.82]$} \\
\hline \multirow[t]{2}{*}{ Market-to-book } & -0.0466 & -0.0420 & -0.0295 & -0.0421 & -0.0390 & 0.0012 & 0.0020 & 0.0033 & 0.0020 & 0.0026 \\
\hline & {$[-1.24]$} & {$[-1.13]$} & {$[-1.06]$} & {$[-1.17]$} & {$[-1.09]$} & {$[0.29]$} & {$[0.50]$} & {$[0.85]$} & {$[0.51]$} & {$[0.66]$} \\
\hline \multirow{2}{*}{ Leverage } & 0.5998 & 0.5929 & 0.4704 & 0.5656 & 0.5617 & 0.2213 & 0.1899 & 0.1616 & 0.2082 & 0.1778 \\
\hline & {$[0.94]$} & {$[0.92]$} & {$[0.75]$} & {$[0.88]$} & {$[0.87]$} & {$[0.94]$} & {$[0.80]$} & {$[0.69]$} & {$[0.89]$} & {$[0.75]$} \\
\hline \multirow[t]{2}{*}{ Sales growth } & 0.6545 & 0.5628 & 0.9753 & 0.7318 & 0.6548 & -0.0247 & -0.0325 & 0.0152 & -0.0112 & -0.0176 \\
\hline & [1.11] & {$[0.96]$} & [1.64] & {$[1.25]$} & {$[1.11]$} & {$[-0.22]$} & {$[-0.28]$} & {$[0.12]$} & {$[-0.09]$} & {$[-0.14]$} \\
\hline \multirow[t]{2}{*}{ Cash holdings } & $-2.5299 * * *$ & $-2.5088^{* * * *}$ & $-2.2035^{* * *}$ & $-2.5579 * * *$ & $-2.5479 * * *$ & -0.1644 & -0.2160 & -0.1666 & -0.1574 & -0.2087 \\
\hline & {$[-3.25]$} & {$[-3.34]$} & {$[-3.07]$} & {$[-3.26]$} & {$[-3.40]$} & {$[-0.57]$} & {$[-0.81]$} & {$[-0.58]$} & {$[-0.55]$} & {$[-0.79]$} \\
\hline \multirow[t]{2}{*}{ Ln(Total assets) } & $-0.2386^{* * *}$ & $-0.1925^{* * *}$ & $-0.2101 * * *$ & $-0.2648 * * *$ & $-0.2271 * * *$ & $-0.1883^{* * *}$ & $-0.1804 * * *$ & $-0.1908 * * *$ & $-0.1977 * * *$ & $-0.1918 * * *$ \\
\hline & {$[-4.31]$} & {$[-3.63]$} & {$[-3.65]$} & {$[-4.23]$} & {$[-3.99]$} & {$[-3.82]$} & {$[-3.70]$} & {$[-3.80]$} & {$[-3.98]$} & {$[-3.89]$} \\
\hline \multirow[t]{2}{*}{ Institutional ownership } & -0.1603 & -0.1463 & -0.0497 & -0.0990 & -0.0676 & 0.1733 & 0.1899 & $0.2343^{*}$ & 0.2217 & $0.2410^{*}$ \\
\hline & {$[-0.40]$} & {$[-0.37]$} & {$[-0.12]$} & {$[-0.24]$} & {$[-0.16]$} & {$[1.23]$} & {$[1.38]$} & {$[1.67]$} & {$[1.60]$} & {$[1.73]$} \\
\hline \multirow[t]{2}{*}{ Institutional ownership concentration } & -3.2694 & -3.5050 & -3.5574 & -3.3249 & -3.5049 & $\begin{array}{l}-0.3266 \\
\end{array}$ & -0.3480 & -0.3999 & -0.4034 & -0.4286 \\
\hline & {$[-1.40]$} & {$[-1.51]$} & {$[-1.48]$} & {$[-1.38]$} & {$[-1.45]$} & {$[-0.74]$} & {$[-0.79]$} & {$[-0.88]$} & {$[-0.88]$} & {$[-0.94]$} \\
\hline \multirow[t]{2}{*}{ Board independence } & -0.8242 & -0.8056 & -0.8107 & -0.8302 & -0.8146 & -0.1778 & -0.1777 & -0.1666 & -0.1708 & -0.1703 \\
\hline & {$[-1.44]$} & {$[-1.42]$} & {$[-1.45]$} & {$[-1.45]$} & {$[-1.44]$} & {$[-1.58]$} & {$[-1.58]$} & {$[-1.51]$} & {$[-1.56]$} & {$[-1.56]$} \\
\hline \multirow[t]{2}{*}{ Board size } & 0.0287 & 0.0277 & 0.0252 & 0.0281 & 0.0272 & -0.0060 & -0.0056 & -0.0057 & -0.0059 & -0.0056 \\
\hline & {$[1.37]$} & {$[1.33]$} & [1.19] & {$[1.30]$} & {$[1.27]$} & {$[-1.02]$} & {$[-0.96]$} & {$[-0.95]$} & {$[-1.00]$} & {$[-0.95]$} \\
\hline \multirow{2}{*}{ Female CEO } & 0.1084 & 0.1092 & 0.0645 & 0.0860 & 0.0832 & 0.0263 & 0.0303 & 0.0327 & 0.0301 & 0.0326 \\
\hline & {$[0.27]$} & {$[0.27]$} & {$[0.16]$} & {$[0.21]$} & {$[0.21]$} & {$[0.20]$} & {$[0.22]$} & {$[0.24]$} & {$[0.23]$} & {$[0.24]$} \\
\hline \multirow[t]{2}{*}{ CEO duality } & -0.0531 & -0.0476 & $\begin{array}{l}-0.0539 \\
-\end{array}$ & -0.0708 & -0.0691 & -0.0062 & -0.0022 & -0.0166 & -0.0186 & -0.0159 \\
\hline & {$[-0.38]$} & {$[-0.35]$} & {$[-0.38]$} & {$[-0.50]$} & {$[-0.49]$} & {$[-0.24]$} & {$[-0.09]$} & {$[-0.65]$} & {$[-0.70]$} & {$[-0.61]$} \\
\hline \multirow[t]{2}{*}{ CEO age } & -0.0009 & -0.0001 & 0.0001 & 0.0003 & 0.0012 & -0.0003 & 0.0002 & -0.0012 & -0.0010 & -0.0006 \\
\hline & {$[-0.11]$} & {$[-0.01]$} & {$[0.01]$} & {$[0.03]$} & {$[0.13]$} & {$[-0.15]$} & {$[0.12]$} & {$[-0.58]$} & {$[-0.50]$} & {$[-0.29]$} \\
\hline \multirow[t]{2}{*}{ CEO shareholding } & -4.8932 & -5.0265 & -4.2717 & -4.0266 & -4.0842 & 0.3870 & 0.3523 & 0.3449 & 0.2841 & 0.2365 \\
\hline & {$[-1.27]$} & {$[-1.35]$} & {$[-1.33]$} & {$[-1.41]$} & {$[-1.43]$} & {$[0.90]$} & {$[0.83]$} & {$[0.75]$} & {$[0.61]$} & {$[0.51]$} \\
\hline Total compensation ( $\$$ millions) & $\begin{array}{c}0.0475^{* * *} \\
{[4.06]}\end{array}$ & & & $\begin{array}{c}0.0358^{* * * *} \\
{[3.01]}\end{array}$ & & $\begin{array}{c}0.0089^{* * *} \\
{[3.08]}\end{array}$ & & & $\begin{array}{c}0.0061^{* *} \\
{[2.35]}\end{array}$ & \\
\hline Equity compensation (\$ millions) & & $\begin{array}{c}0.0577 * * * \\
{[3.47]}\end{array}$ & & & $\begin{array}{c}0.0450 * * * \\
{[3.01]}\end{array}$ & & $\begin{array}{c}0.0102 * * * \\
{[2.87]}\end{array}$ & & & $\begin{array}{c}0.0072 * * \\
{[2.23]}\end{array}$ \\
\hline \multirow[t]{2}{*}{ Cash compensation ( $\$$ millions) } & & -0.0315 & & & -0.0499 & & -0.0069 & & & -0.0086 \\
\hline & & {$[-0.45]$} & & & {$[-0.75]$} & & {$[-0.61]$} & & & {$[-0.92]$} \\
\hline \multirow[t]{2}{*}{ Delta (\$ millions) } & & & -0.0410 & -0.0537 & -0.0581 & & & 0.0024 & 0.0008 & 0.0021 \\
\hline & & & {$[-0.47]$} & {$[-0.46]$} & {$[-0.54]$} & & & {$[0.16]$} & {$[0.05]$} & {$[0.14]$} \\
\hline \multirow[t]{2}{*}{ Vega (\$ millions) } & & & $0.8108 * * *$ & $0.5236^{* *}$ & $0.6037 * *$ & & & $0.2382 * * *$ & $0.2040^{* * *}$ & $0.2083 * * *$ \\
\hline & & & {$[3.36]$} & {$[2.08]$} & {$[2.25]$} & & & {$[3.93]$} & {$[3.49]$} & {$[3.42]$} \\
\hline $\mathrm{R}^{2}$ & 0.11 & 0.11 & 0.11 & 0.11 & 0.12 & 0.1079 & 0.1082 & 0.1137 & 0.1173 & 0.1182 \\
\hline $\mathrm{N}$ & 1144 & 1144 & 1132 & 1132 & 1132 & 1144 & 1144 & 1132 & 1132 & 1132 \\
\hline
\end{tabular}

This table presents regressions results on the determinants of bank merger announcements. The dependent variable is equal to 1 if a megamerger announcement is made by a bank in a given year, and 0 otherwise. The regressions in Panel A are estimated using a probit model. The regressions in Panel B are estimated using a linear probability model with firm-level fixed effects. All independent variables are lagged by one year relative to the dependent variable. Intercepts and year dummies are included in all regressions but suppressed for brevity. See the appendix for variable definitions. The $t$-statistics based on robust standard errors clustered by firm are reported in brackets. $* * *, * *$, and $*$ indicate statistical significance at the $1 \%, 5 \%$, and $10 \%$ levels, respectively. 
Table 4

Bank Mergers and CEO Compensation

\begin{tabular}{|c|c|c|c|c|c|c|c|c|c|c|}
\hline & \multicolumn{6}{|c|}{ Panel A: CEO pay } & \multicolumn{4}{|c|}{ Panel B: CEO pay sensitivity } \\
\hline & & & [3] & & {$[5]$} & & {$[7]$} & {$[8]$} & [9] & {$[10]$} \\
\hline & $\begin{array}{c}\text { Total } \\
\text { compensation }\end{array}$ & $\begin{array}{c}\text { Total } \\
\text { compensation }\end{array}$ & $\begin{array}{c}\text { Equity } \\
\text { compensation }\end{array}$ & $\begin{array}{c}\text { Equity } \\
\text { compensation }\end{array}$ & $\begin{array}{c}\text { Cash } \\
\text { compensation }\end{array}$ & $\begin{array}{c}\text { Cash } \\
\text { compensation }\end{array}$ & Delta & Delta & Vega & Vega \\
\hline \multirow{2}{*}{$\begin{array}{l}\text { Total assets at } t 3 \\
\text { (\$ millions) }\end{array}$} & $0.0050^{* * *}$ & $0.0047 * *$ & $0.0044 * * *$ & $0.0041 * * *$ & 0.0008 & 0.0007 & 0.0004 & 0.0004 & 0.0001 & 0.0001 \\
\hline & [3.30] & [2.57] & [4.90] & [3.56] & [1.05] & [1.04] & {$[0.82]$} & {$[0.91]$} & {$[0.82]$} & {$[0.82]$} \\
\hline \multirow{2}{*}{$\begin{array}{l}\text { Assets acquired in } \\
\text { megamergers ( } \$ \text { millions) }\end{array}$} & $0.1875^{* * *}$ & & $0.1684 * * *$ & & 0.0239 & & $-0.0165^{* *}$ & & -0.0008 & \\
\hline & [5.11] & & [2.99] & & {$[0.74]$} & & {$[-2.03]$} & & {$[-0.17]$} & \\
\hline \multirow{2}{*}{$\begin{array}{l}\text { Assets acquired in all mergers } \\
\text { (\$ millions) }\end{array}$} & & $0.1741^{* * *}$ & & $0.1510^{* * *}$ & & 0.0226 & & $-0.0157^{*}$ & & -0.0010 \\
\hline & & [7.08] & & {$[4.00]$} & & [0.72] & & {$[-1.89]$} & & {$[-0.21]$} \\
\hline \multirow{2}{*}{$\begin{array}{l}\text { Non-megamerger growth } \\
\text { (\$ millions) }\end{array}$} & $0.0135^{* * *}$ & & $0.0097 *$ & & $0.0026^{* * *}$ & & $0.0027 * * *$ & & $0.0014 * * *$ & \\
\hline & [3.04] & & [1.80] & & [3.90] & & [3.55] & & [5.03] & \\
\hline \multirow[t]{2}{*}{$\begin{array}{l}\text { Non-merger growth } \\
\text { (\$ millions) }\end{array}$} & & $0.0124 * * *$ & & $0.0090 *$ & & $0.0024 * * *$ & & $0.0029 * * *$ & & $0.0014 * * *$ \\
\hline & & [3.22] & & [1.79] & & [2.65] & & [3.11] & & [4.61] \\
\hline \multirow{2}{*}{$\begin{array}{l}\text { Change in firm value due to } \\
\text { change in industry index } \\
\text { (\$ millions) }\end{array}$} & $0.1482 * * *$ & $0.1602 * * *$ & $0.0727 * * *$ & $0.0850 * * *$ & $0.0466 * * *$ & $0.0480 * * *$ & $0.0282 * * *$ & $0.0270 * * *$ & $0.0079 * * *$ & $0.0079 * * *$ \\
\hline & [6.88] & {$[6.78]$} & {$[3.78]$} & {$[3.73]$} & [4.01] & {$[4.65]$} & [5.19] & [5.42] & [2.69] & [2.87] \\
\hline \multirow[t]{2}{*}{$\begin{array}{l}\text { Change in firm value due to } \\
\text { idiosyncratic change } \\
\text { (\$ millions) }\end{array}$} & $0.1056^{* * *}$ & $0.1147 * * *$ & $0.0522 * *$ & $0.0618^{* *}$ & $0.0323 * * *$ & $0.0334 * * *$ & $0.0159^{*}$ & $0.0150 *$ & 0.0019 & 0.0019 \\
\hline & [4.69] & [4.86] & [2.18] & [2.28] & [4.66] & [5.25] & [1.95] & [1.88] & {$[0.82]$} & [0.84] \\
\hline \multirow[t]{2}{*}{ Return on assets $\left(\times 10^{5}\right)$} & $0.2866^{* * *}$ & $0.2788^{* * *}$ & $0.2613^{* * *}$ & $0.2531 * * *$ & -0.0060 & -0.0068 & 0.0218 & 0.0225 & $0.0100^{* *}$ & $0.0101 * *$ \\
\hline & [3.60] & [3.46] & [2.87] & {$[2.75]$} & {$[-0.58]$} & {$[-0.65]$} & [1.36] & [1.42] & [2.39] & {$[2.41]$} \\
\hline Female CEO $\left(\times 10^{3}\right)$ & $\begin{array}{r}-0.5712 \\
\lceil-1511\end{array}$ & $\begin{array}{l}-0.5638 \\
\lceil-150]\end{array}$ & $\begin{array}{l}-0.4181 \\
\Gamma-143\rceil\end{array}$ & $\begin{array}{l}-0.4106 \\
\lceil-143]\end{array}$ & $\begin{array}{l}-0.1837 * * \\
{[-198]}\end{array}$ & $-0.1829^{*}$ & -0.1282 & $\begin{array}{l}-0.1290 \\
\lceil-1.39]\end{array}$ & $\begin{array}{l}-0.0105 \\
\lceil-048]\end{array}$ & $\begin{array}{l}-0.0105 \\
-0.048]\end{array}$ \\
\hline \multirow[t]{2}{*}{ CEO duality $\left(\times 10^{3}\right)$} & $1.6381 * * *$ & $1.6342 * * *$ & $0.9633 * * *$ & $0.9584 * * *$ & $0.3476^{* * *}$ & $0.3473 * * *$ & $0.1648 * * *$ & $0.1650^{* * *}$ & $0.0736 * * *$ & $0.0736 * * *$ \\
\hline & {$[4.73]$} & {$[4.76]$} & {$[3.70]$} & {$[3.74]$} & {$[5.54]$} & {$[5.54]$} & {$[3.48]$} & [3.48] & [3.82] & [3.83] \\
\hline \multirow[t]{2}{*}{ CEO age $\left(\times 10^{3}\right)$} & -0.0088 & -0.0093 & -0.0180 & -0.0184 & 0.0044 & 0.0043 & 0.0231 & 0.0231 & 0.0006 & 0.0006 \\
\hline & {$[-0.48]$} & {$[-0.51]$} & {$[-1.55]$} & {$[-1.58]$} & {$[1.08]$} & {$[1.07]$} & {$[1.60]$} & {$[1.60]$} & {$[0.55]$} & {$[0.57]$} \\
\hline \multirow[t]{2}{*}{ CEO shareholding $\left(\times 10^{5}\right)$} & $-0.1033^{*}$ & $-0.1011^{*}$ & -0.0447 & -0.0431 & $-0.0272 * *$ & $-0.0269^{* *}$ & $0.1277 * * *$ & $0.1274 * * *$ & -0.0033 & -0.0033 \\
\hline & {$[-1.73]$} & {$[-1.69]$} & {$[-0.98]$} & {$[-0.94]$} & {$[-2.28]$} & {$[-2.24]$} & {$[2.88]$} & [2.88] & {$[-1.05]$} & {$[-1.06]$} \\
\hline Adj. $R^{2}$ & 0.44 & 0.44 & 0.39 & 0.39 & 0.34 & 0.34 & 0.33 & 0.33 & 0.44 & 0.44 \\
\hline $\mathrm{N}$ & 1753 & 1753 & 1753 & 1753 & 1753 & 1753 & 1720 & 1720 & 1718 & 1718 \\
\hline
\end{tabular}

This table presents OLS regressions of CEO pay and pay sensitivity on merger growth and control variables. Intercepts and year dummies are included in all regressions but suppressed for brevity

The dependent variables are in thousands of U.S. dollars. See the appendix for variable definitions. The $t$-statistics based on robust standard errors clustered by firm are reported in brackets. $* * *$,

**, and * indicate statistical significance at the $1 \%, 5 \%$, and $10 \%$ levels, respectively. 
Table 5

Bank Mergers and CEO Compensation (Firm-Fixed Effects)

\begin{tabular}{|c|c|c|c|c|c|c|c|c|c|c|}
\hline & \multicolumn{6}{|c|}{ Panel A: CEO pay } & \multicolumn{4}{|c|}{ Panel B: CEO pay sensitivity } \\
\hline & {$[1]$} & [2] & [3] & [4] & [5] & {$[6]$} & [7] & {$[8]$} & [9] & {$[10]$} \\
\hline & $\begin{array}{c}\text { Total } \\
\text { compensation }\end{array}$ & $\begin{array}{c}\text { Total } \\
\text { compensation }\end{array}$ & $\begin{array}{c}\text { Equity } \\
\text { compensation }\end{array}$ & $\begin{array}{c}\text { Equity } \\
\text { compensation }\end{array}$ & $\begin{array}{c}\text { Cash } \\
\text { compensation }\end{array}$ & $\begin{array}{c}\text { Cash } \\
\text { compensation }\end{array}$ & Delta & Delta & Vega & Vega \\
\hline Total assets at $t-3$ & -0.0005 & -0.0009 & 0.0012 & 0.0008 & -0.0012 & -0.0012 & 0.0002 & 0.0002 & 0.0001 & 0.0000 \\
\hline & {$[-0.35]$} & {$[-0.50]$} & [0.97] & [0.47] & {$[-1.45]$} & {$[-1.50]$} & [0.32] & [0.40] & [0.29] & {$[0.22]$} \\
\hline $\begin{array}{l}\text { Assets acquired in megamergers } \\
\text { (\$ millions) }\end{array}$ & $0.1265^{*}$ & & $0.1270^{*}$ & & 0.0096 & & $-0.0135^{* *}$ & & -0.0004 & \\
\hline & [1.82] & & [1.72] & & [0.33] & & {$[-2.23]$} & & {$[-0.10]$} & \\
\hline $\begin{array}{l}\text { Assets acquired in all mergers } \\
\text { (\$ millions) }\end{array}$ & & $0.1054 * *$ & & $0.1049 * *$ & & 0.0099 & & $-0.0119 * *$ & & -0.0013 \\
\hline & & [2.18] & & [2.04] & & [0.36] & & {$[-2.08]$} & & {$[-0.33]$} \\
\hline $\begin{array}{l}\text { Non-megamerger growth } \\
\text { (\$ millions) }\end{array}$ & 0.0199 & & 0.0166 & & $-0.0024 * *$ & & $0.0015^{* *}$ & & $0.0007 * * *$ & \\
\hline & {$[1.16]$} & & [1.04] & & {$[-2.05]$} & & [2.02] & & [5.12] & \\
\hline $\begin{array}{l}\text { Non-merger growth } \\
\text { (\$ millions) }\end{array}$ & & 0.0199 & & 0.0167 & & $-0.0026^{*}$ & & $0.0015^{*}$ & & $0.0008^{* * *}$ \\
\hline & & [1.19] & & [1.08] & & {$[-1.89]$} & & [1.93] & & [4.71] \\
\hline $\begin{array}{l}\text { Change in firm value due to } \\
\text { change in industry index }\end{array}$ & $0.0638^{* * *}$ & $0.0772 * * *$ & 0.0196 & 0.0333 & $0.0224 * *$ & $0.0232 * * *$ & $0.0229 * * *$ & $0.0215^{* * *}$ & 0.0029 & 0.0030 \\
\hline & [4.22] & [3.56] & [1.10] & {$[1.27]$} & [2.39] & [3.10] & [5.29] & [5.17] & [0.93] & {$[1.02]$} \\
\hline $\begin{array}{l}\text { Change in firm value due to } \\
\text { idiosyncratic change ( } \$ \text { millions) }\end{array}$ & $0.0698 * *$ & $0.0801 * * *$ & 0.0332 & 0.0438 & $0.0260 * * *$ & $0.0266^{* * *}$ & $0.0140^{*}$ & $0.0129 *$ & 0.0001 & 0.0003 \\
\hline & {$[2.34]$} & {$[2.78]$} & [1.09] & {$[1.43]$} & {$[3.72]$} & [4.08] & {$[1.87]$} & {$[1.76]$} & {$[0.05]$} & {$[0.11]$} \\
\hline Return on assets $\left(\times 10^{5}\right)$ & $\begin{array}{c}0.2672 * * * \\
{[2.67]}\end{array}$ & $\begin{array}{c}0.2609 * * * \\
{[2.66]}\end{array}$ & $\begin{array}{c}0.2186^{* *} \\
{[2.46]}\end{array}$ & $\begin{array}{c}0.2120^{* *} \\
{[2.44]}\end{array}$ & $\begin{array}{c}0.0487^{* * * *} \\
{[3.67]}\end{array}$ & $\begin{array}{c}0.0486 * * * \\
{[3.64]}\end{array}$ & $\begin{array}{c}0.0384^{*} \\
{[1.88]}\end{array}$ & $\begin{array}{c}0.0389^{*} \\
{[1.89]}\end{array}$ & $\begin{array}{c}0.0080^{*} \\
{[1.80]}\end{array}$ & $\begin{array}{c}0.0078^{*} \\
{[1.77]}\end{array}$ \\
\hline Female CEO $\left(\times 10^{3}\right)$ & $\begin{array}{r}-0.5867 \\
{[-0.67]}\end{array}$ & $\begin{array}{r}-0.5779 \\
{[-0.66]}\end{array}$ & $\begin{array}{l}-0.0758 \\
{[-0.21]}\end{array}$ & $\begin{array}{r}-0.0665 \\
{[-0.19]}\end{array}$ & $\begin{array}{l}-0.3540^{*} \\
{[-1.97]}\end{array}$ & $\begin{array}{l}-0.3547 * \\
{[-1.97]}\end{array}$ & $\begin{array}{l}0.0191 \\
{[0.21]}\end{array}$ & 0.0190 & -0.0122 & -0.0116 \\
\hline CEO duality $\left(\times 10^{3}\right)$ & $\begin{array}{l}0.3163 \\
{[0.65]}\end{array}$ & $\begin{array}{l}0.3013 \\
{[0.63]}\end{array}$ & $\begin{array}{l}0.1214 \\
{[0.29]}\end{array}$ & $\begin{array}{l}0.1064 \\
{[0.27]}\end{array}$ & $\begin{array}{c}0.1298^{*} \\
{[1.73]}\end{array}$ & $\begin{array}{c}0.1296^{*} \\
{[1.73]}\end{array}$ & $\begin{array}{l}0.0688 \\
{[1.23]}\end{array}$ & $\begin{array}{l}{[0.2069} \\
0.069 \\
{[1.25]}\end{array}$ & $\begin{array}{l}0.0281 \\
{[1.13]}\end{array}$ & $\begin{array}{l}0.0278 \\
{[1.12]}\end{array}$ \\
\hline CEO age $\left(\times 10^{3}\right)$ & $\begin{array}{l}0.0220 \\
{[0.90]}\end{array}$ & $\begin{array}{l}0.0218 \\
{[0.89]}\end{array}$ & $\begin{array}{r}-0.0161 \\
{[-0.93]}\end{array}$ & $\begin{array}{l}-0.0162 \\
{[-0.94]}\end{array}$ & $\begin{array}{c}0.0134^{*} \\
{[1.89]}\end{array}$ & $\begin{array}{c}0.0132 * \\
{[1.83]}\end{array}$ & $\begin{array}{l}0.0215^{* * *} \\
{[2.62]}\end{array}$ & $\begin{array}{l}0.0216^{* * * *} \\
{[2.63]}\end{array}$ & $\begin{array}{l}0.0041^{* *} \\
{[2.58]}\end{array}$ & $\begin{array}{c}0.0041^{* * *} \\
{[2.65]}\end{array}$ \\
\hline CEO shareholding $\left(\times 10^{5}\right)$ & $\begin{array}{l}0.0877 \\
{[1.44]}\end{array}$ & $\begin{array}{l}0.0885 \\
{[1.45]}\end{array}$ & $\begin{array}{l}0.0909 \\
{[1.63]}\end{array}$ & $\begin{array}{l}0.0918 \\
{[1.65]}\end{array}$ & $\begin{array}{r}-0.0105 \\
{[-0.76]}\end{array}$ & $\begin{array}{l}-0.0103 \\
{[-0.75]}\end{array}$ & $\begin{array}{c}0.0553 * * * \\
{[3.88]}\end{array}$ & $\begin{array}{c}0.0552 * * * \\
{[3.87]}\end{array}$ & $\begin{array}{l}0.0035 \\
{[1.22]}\end{array}$ & $\begin{array}{l}0.0034 \\
{[1.21]}\end{array}$ \\
\hline Adj. $R^{2}$ & 0.22 & 0.22 & 0.16 & 0.15 & 0.20 & 0.20 & 0.27 & 0.27 & 0.32 & 0.32 \\
\hline $\mathrm{N}$ & 1753 & 1753 & 1753 & 1753 & 1753 & 1753 & 1720 & 1720 & 1718 & 1718 \\
\hline
\end{tabular}

This table presents firm-fixed effects regressions of CEO pay and pay sensitivity on merger growth and control variables. Intercepts and year dummies are included in all regressions but suppressed for brevity. The dependent variables are in thousands of U.S. dollars. See the appendix for variable definitions. The $t$-statistics based on robust standard errors clustered by firm are reported in brackets. $* * *, * *$, and $*$ indicate statistical significance at the $1 \%, 5 \%$, and $10 \%$ levels, respectively. 
Table 6

Bank Mergers and CEO Compensation (Dynamic OLS and GMM)

\begin{tabular}{|c|c|c|c|c|c|c|}
\hline \multirow{2}{*}{$\begin{array}{l}\text { Panel A: CEO pay } \\
\text { Pay measure }=\end{array}$} & \multicolumn{3}{|c|}{ Dynamic OLS } & \multicolumn{3}{|c|}{ Dynamic panel GMM } \\
\hline & $\begin{array}{c}1] \\
\text { Total } \\
\text { compensation }\end{array}$ & $\begin{array}{c}2] \\
\text { Equity } \\
\text { compensation }\end{array}$ & $\begin{array}{c}3] \\
\text { Cash } \\
\text { compensation }\end{array}$ & $\begin{array}{c}4] \\
\text { Total } \\
\text { compensation }\end{array}$ & $\begin{array}{c}5] \\
\text { Equity } \\
\text { compensation }\end{array}$ & $\begin{array}{c}6] \\
\text { Cash } \\
\text { compensation }\end{array}$ \\
\hline \multirow[t]{2}{*}{$\begin{array}{l}\text { Total assets at } t-3 \\
\text { ( } \$ \text { millions })\end{array}$} & $0.0023 * * *$ & $0.0024 * * *$ & 0.0006 & 0.0040 & 0.0040 & $0.0013 * *$ \\
\hline & {$[3.25]$} & {$[5.47]$} & {$[1.18]$} & {$[1.29]$} & {$[1.32]$} & {$[2.22]$} \\
\hline \multirow{2}{*}{$\begin{array}{l}\text { Assets acquired in } \\
\text { megamergers } \\
\text { (\$ millions) }\end{array}$} & $0.1517^{* *}$ & $0.1471 *$ & 0.0174 & $0.2523 * *$ & $0.2978 * * *$ & 0.0260 \\
\hline & {$[2.05]$} & {$[1.80]$} & {$[0.76]$} & {$[2.32]$} & {$[3.18]$} & {$[0.81]$} \\
\hline \multirow{2}{*}{$\begin{array}{l}\text { Non-megamerger growth } \\
\text { (\$ millions) }\end{array}$} & -0.0047 & 0.0004 & -0.0018 & -0.0017 & -0.0040 & 0.0008 \\
\hline & {$[-1.13]$} & {$[0.08]$} & {$[-1.03]$} & {$[-0.31]$} & {$[-0.72]$} & {$[0.68]$} \\
\hline \multirow[t]{2}{*}{$\begin{array}{l}\text { Change in firm value due } \\
\text { to change in industry } \\
\text { index ( } \$ \text { millions) }\end{array}$} & $0.0850 * * *$ & $0.0517 * *$ & $0.0135 * *$ & 0.0529 & 0.0321 & -0.0098 \\
\hline & {$[2.91]$} & {$[2.18]$} & {$[2.47]$} & {$[1.33]$} & {$[0.69]$} & {$[-1.13]$} \\
\hline \multirow[t]{2}{*}{$\begin{array}{l}\text { Change in firm value due } \\
\text { to idiosyncratic change } \\
\text { (\$ millions) }\end{array}$} & $0.1189 * * *$ & $0.0683 * *$ & $0.0175 * * *$ & 0.0589 & 0.0237 & $-0.0263 * *$ \\
\hline & {$[3.41]$} & {$[2.29]$} & {$[2.75]$} & {$[1.28]$} & {$[0.54]$} & {$[-2.57]$} \\
\hline \multirow[t]{2}{*}{ Return on assets $\left(\times 10^{5}\right)$} & 0.0556 & $0.1073 * *$ & -0.0063 & 0.1391 & 0.0815 & -0.0383 \\
\hline & {$[1.40]$} & {$[2.45]$} & {$[-1.20]$} & {$[0.48]$} & {$[0.20]$} & {$[-0.86]$} \\
\hline \multirow[t]{2}{*}{ Female CEO $\left(\times 10^{3}\right)$} & -0.1006 & -0.0968 & -0.0937 & -0.2372 & 0.0599 & -0.3387 \\
\hline & {$[-0.38]$} & {$[-0.66]$} & {$[-1.42]$} & {$[-0.12]$} & {$[0.02]$} & {$[-1.53]$} \\
\hline \multirow[t]{2}{*}{ CEO duality $\left(\times 10^{3}\right)$} & $0.5780 * * *$ & $0.4495 * *$ & 0.0614 & 0.8926 & 1.0140 & 0.3286 \\
\hline & {$[2.76]$} & {$[2.42]$} & {$[1.57]$} & {$[0.75]$} & {$[1.04]$} & {$[1.55]$} \\
\hline \multirow[t]{2}{*}{ CEO age $\left(\times 10^{3}\right)$} & -0.0043 & -0.0119 & 0.0023 & -0.0122 & -0.0085 & 0.0187 \\
\hline & {$[-0.42]$} & {$[-1.48]$} & {$[1.01]$} & {$[-0.20]$} & {$[-0.16]$} & {$[1.53]$} \\
\hline \multirow[t]{2}{*}{$\begin{array}{l}\text { CEO shareholding } \\
\left(\times 10^{5}\right)\end{array}$} & -0.0485 & -0.0291 & -0.0105 & 0.2307 & 0.2481 & -0.0168 \\
\hline & {$[-1.48]$} & {$[-0.87]$} & {$[-1.27]$} & {$[1.03]$} & {$[1.39]$} & {$[-0.64]$} \\
\hline \multirow[t]{2}{*}{ Pay measure (lag 1) } & $0.4466 * * *$ & $0.3461 * * *$ & $0.6486 * * *$ & $0.5021 * * *$ & $0.3954 * *$ & $0.4754 * * *$ \\
\hline & {$[12.45]$} & {$[5.45]$} & {$[8.55]$} & {$[4.27]$} & {$[2.37]$} & {$[6.60]$} \\
\hline \multirow[t]{2}{*}{ Pay measure (lag 2) } & $0.2323 * * *$ & $0.1761 * * *$ & 0.0793 & 0.0728 & 0.0300 & \\
\hline & [9.33] & {$[6.31]$} & {$[0.79]$} & {$[1.44]$} & {$[0.39]$} & \\
\hline Adj. $R^{2}$ & 0.63 & 0.49 & 0.64 & & & \\
\hline $\mathrm{N}$ & 1500 & 1500 & 1500 & 1500 & 1500 & 1630 \\
\hline $\mathrm{AR}(1)$ & & & & $-3.09 * * *$ & $-2.33 * *$ & $-1.81^{*}$ \\
\hline $\operatorname{AR}(2)$ & & & & -0.68 & -0.06 & -1.04 \\
\hline Hansen J & & & & 21.35 & 25.40 & 11.74 \\
\hline
\end{tabular}




\begin{tabular}{|c|c|c|c|c|}
\hline \multirow[t]{2}{*}{ Panel B: CEO pay sensitivity } & \multicolumn{2}{|c|}{ Dynamic OLS } & \multicolumn{2}{|c|}{ Dynamic panel GMM } \\
\hline & {$[1]$} & [2] & {$[3]$} & {$[4]$} \\
\hline Pay sensitivity measure $=$ & Delta & Vega & Delta & Vega \\
\hline \multirow{2}{*}{$\begin{array}{l}\text { Total assets at } t 3 \\
\text { ( } \$ \text { millions) }\end{array}$} & -0.0000 & 0.0000 & $-0.0003 * * *$ & -0.0000 \\
\hline & {$[-0.18]$} & {$[1.31]$} & {$[-2.62]$} & {$[-0.32]$} \\
\hline \multirow{2}{*}{$\begin{array}{l}\text { Assets acquired in megamergers } \\
\text { (\$ millions) }\end{array}$} & $-0.0045^{* *}$ & -0.0009 & $-0.0103 * * *$ & -0.0127 \\
\hline & {$[-2.00]$} & {$[-0.79]$} & {$[-3.64]$} & {$[-0.92]$} \\
\hline \multirow{2}{*}{$\begin{array}{l}\text { Non-megamerger growth } \\
\text { (\$ millions) }\end{array}$} & -0.0003 & -0.0001 & $0.0010^{* *}$ & 0.0002 \\
\hline & {$[-0.81]$} & {$[-0.61]$} & {$[2.48]$} & {$[0.79]$} \\
\hline \multirow{2}{*}{$\begin{array}{l}\text { Change in firm value due to change in } \\
\text { industry index (\$ millions) }\end{array}$} & $0.0121^{* * *}$ & $0.0017 * *$ & $0.0085^{* *}$ & 0.0003 \\
\hline & {$[5.03]$} & {$[2.39]$} & {$[2.56]$} & {$[0.21]$} \\
\hline \multirow{2}{*}{$\begin{array}{l}\text { Change in firm value due to idiosyncratic } \\
\text { change ( } \$ \text { millions) }\end{array}$} & $0.0101 * * *$ & $0.0027 * *$ & 0.0017 & 0.0003 \\
\hline & [3.01] & [2.09] & {$[0.57]$} & {$[0.11]$} \\
\hline \multirow[t]{2}{*}{ Return on assets $\left(\times 10^{5}\right)$} & -0.0071 & 0.0013 & -0.0060 & -0.0058 \\
\hline & {$[-1.49]$} & {$[0.95]$} & {$[-0.36]$} & {$[-0.92]$} \\
\hline \multirow[t]{2}{*}{ Female CEO $\left(\times 10^{3}\right)$} & 0.0142 & -0.0060 & 0.0611 & -0.0188 \\
\hline & {$[0.65]$} & {$[-0.74]$} & {$[0.56]$} & {$[-0.32]$} \\
\hline \multirow{2}{*}{ CEO duality $\left(\times 10^{3}\right)$} & $0.0434^{*}$ & 0.0104 & 0.0176 & -0.0259 \\
\hline & {$[1.74]$} & {$[1.53]$} & {$[0.29]$} & {$[-0.73]$} \\
\hline \multirow[t]{2}{*}{ CEO age $\left(\times 10^{3}\right)$} & 0.0043 & 0.0005 & -0.0010 & -0.0007 \\
\hline & {$[1.53]$} & [1.12] & {$[-0.22]$} & {$[-0.40]$} \\
\hline \multirow[t]{2}{*}{ CEO shareholding $\left(\times 10^{5}\right)$} & 0.0125 & -0.0018 & $-0.0384 * *$ & 0.0058 \\
\hline & {$[0.78]$} & {$[-1.49]$} & {$[-2.46]$} & {$[0.88]$} \\
\hline \multirow[t]{2}{*}{ Pay sensitivity measure (lag 1) } & $0.9094 * * *$ & $0.8337 * * *$ & $0.9783^{* * *}$ & $0.9522 * * *$ \\
\hline & {$[24.47]$} & {$[10.93]$} & {$[15.74]$} & [11.09] \\
\hline \multirow[t]{2}{*}{ Pay sensitivity measure (lag 2) } & 0.0763 & 0.0743 & & \\
\hline & {$[1.14]$} & {$[1.16]$} & & \\
\hline Adj. $R^{2}$ & 0.87 & 0.84 & & \\
\hline $\mathrm{N}$ & 1436 & 1437 & 1578 & 1577 \\
\hline $\mathrm{AR}(1)$ & & & $-2.35 * *$ & $-2.58^{* *}$ \\
\hline $\operatorname{AR}(2)$ & & & -1.13 & 0.98 \\
\hline Hansen J & & & 20.29 & 26.28 \\
\hline
\end{tabular}

Notes:

This table presents regressions of CEO pay and pay sensitivity on megamerger growth and control variables. The regressions are estimated using dynamic OLS and two-step dynamic panel system GMM estimators, respectively. Intercepts and year dummies are included in all regressions but suppressed for brevity. In the dynamic OLS model, lagged dependent variables are included as regressors, and the $t$-statistics in brackets are based on robust standard errors clustered by firm. In the dynamic panel GMM estimation, all independent variables are treated as endogenous except for year dummies, and these endogenous variables are instrumented by two of their past values; the $t$-statistics in brackets are based on finite-sample corrected robust standard errors (Windmeijer, 2005). The dependent variables are in thousands of U.S. dollars. See the appendix for variable definitions. ${ }^{* *}, * *$, and $*$ indicate statistical significance at the $1 \%, 5 \%$, and $10 \%$ levels, respectively. 
Table 7

Bank Mergers and CEO Compensation (DiD Analysis)

\begin{tabular}{|c|c|c|c|c|c|c|c|c|}
\hline \multicolumn{9}{|c|}{ Panel A: DiD tests for CEO pay } \\
\hline \multicolumn{9}{|c|}{ Estimated propensity score distributions: } \\
\hline Propensity scores & $\mathrm{N}$ & Min & P5 & Median & Mean & P95 & Max & SD \\
\hline Treatment & 45 & 0.008 & 0.032 & 0.150 & 0.159 & 0.285 & 0.426 & 0.088 \\
\hline Control & 45 & 0.008 & 0.032 & 0.145 & 0.157 & 0.287 & 0.428 & 0.087 \\
\hline Difference & - & 0.000 & 0.000 & 0.002 & 0.004 & 0.010 & 0.047 & 0.007 \\
\hline \multicolumn{9}{|l|}{ Post-matching mean differences: } \\
\hline Variable & \multicolumn{3}{|c|}{ Treatment } & \multicolumn{2}{|l|}{ Control } & Difference & \multicolumn{2}{|r|}{$t$-statistic } \\
\hline Return on assets & \multicolumn{3}{|c|}{0.026} & \multicolumn{2}{|l|}{0.024} & 0.002 & \multicolumn{2}{|r|}{0.679} \\
\hline Market-to-book & \multicolumn{3}{|c|}{2.336} & \multicolumn{2}{|l|}{2.305} & 0.031 & \multicolumn{2}{|r|}{0.098} \\
\hline Leverage & \multicolumn{3}{|c|}{0.188} & \multicolumn{2}{|l|}{0.187} & 0.001 & \multicolumn{2}{|r|}{0.056} \\
\hline Sales growth & \multicolumn{3}{|c|}{0.737} & \multicolumn{2}{|l|}{0.752} & -0.015 & \multicolumn{2}{|r|}{-0.884} \\
\hline Cash holdings & \multicolumn{3}{|c|}{0.069} & \multicolumn{2}{|l|}{0.055} & 0.014 & \multicolumn{2}{|r|}{0.802} \\
\hline Ln(Total assets) & \multicolumn{3}{|c|}{9.445} & \multicolumn{2}{|l|}{9.317} & 0.128 & \multicolumn{2}{|r|}{0.501} \\
\hline Institutional ownership & \multicolumn{3}{|c|}{0.536} & \multicolumn{2}{|l|}{0.556} & -0.021 & \multicolumn{2}{|r|}{-0.502} \\
\hline $\begin{array}{l}\text { Institutional ownership } \\
\text { concentration }\end{array}$ & & 0.048 & & 0.046 & & 0.002 & & 0.416 \\
\hline Board independence & & 0.695 & & 0.731 & & -0.037 & & -1.484 \\
\hline Board size & & 13.400 & & 12.733 & & 0.667 & & 0.954 \\
\hline Female CEO & & 0.000 & & 0.000 & & 0.000 & & - \\
\hline CEO duality & & 0.711 & & 0.644 & & 0.067 & & 0.671 \\
\hline CEO age & & 56.133 & & 54.711 & & 1.422 & & 1.185 \\
\hline CEO shareholding & & 0.008 & & 0.009 & & -0.001 & & -0.387 \\
\hline Bank growth (\$ billions) & & 2.843 & & 3.175 & & -0.332 & & -0.185 \\
\hline$\Delta$ Total compensation (\$ millions) & & 0.995 & & 0.354 & & 0.640 & & 1.205 \\
\hline$\Delta$ Equity compensation ( $\$$ millions $)$ & & 0.778 & & -0.103 & & 0.882 & & 1.621 \\
\hline$\Delta$ Cash compensation $(\$$ millions $)$ & & 0.119 & & 0.345 & & -0.226 & & -1.338 \\
\hline DiD estimators: & & & & & & & & \\
\hline & & [1] & & & [2] & & & [3] \\
\hline & Mean & $\begin{array}{l}\text { ence before } \\
\text { ttment - co }\end{array}$ & amerger & $\begin{array}{r}\text { Mean diff } \\
\text { (tre }\end{array}$ & ice after $n$ & $\begin{array}{l}\text { gamerger } \\
\text { l) }\end{array}$ & $\begin{array}{l}\text { Mean D } \\
\quad(\text { after }\end{array}$ & $\begin{array}{l}\text { iD estimator } \\
\text { - before) }\end{array}$ \\
\hline Total compensation & & 550 & & & 1174 & & & $624 *$ \\
\hline & & {$[0.58]$} & & & {$[1.08]$} & & & $1.70]$ \\
\hline Equity compensation & & 106 & & & $407 *$ & & & $301 *$ \\
\hline & & {$[0.51]$} & & & [1.95] & & & $1.70]$ \\
\hline Cash compensation & & -2 & & & 15 & & & 17 \\
\hline & & {$[-0.01]$} & & & {$[0.05]$} & & & $0.12]$ \\
\hline
\end{tabular}


Panel B: DiD tests for CEO pay sensitivity

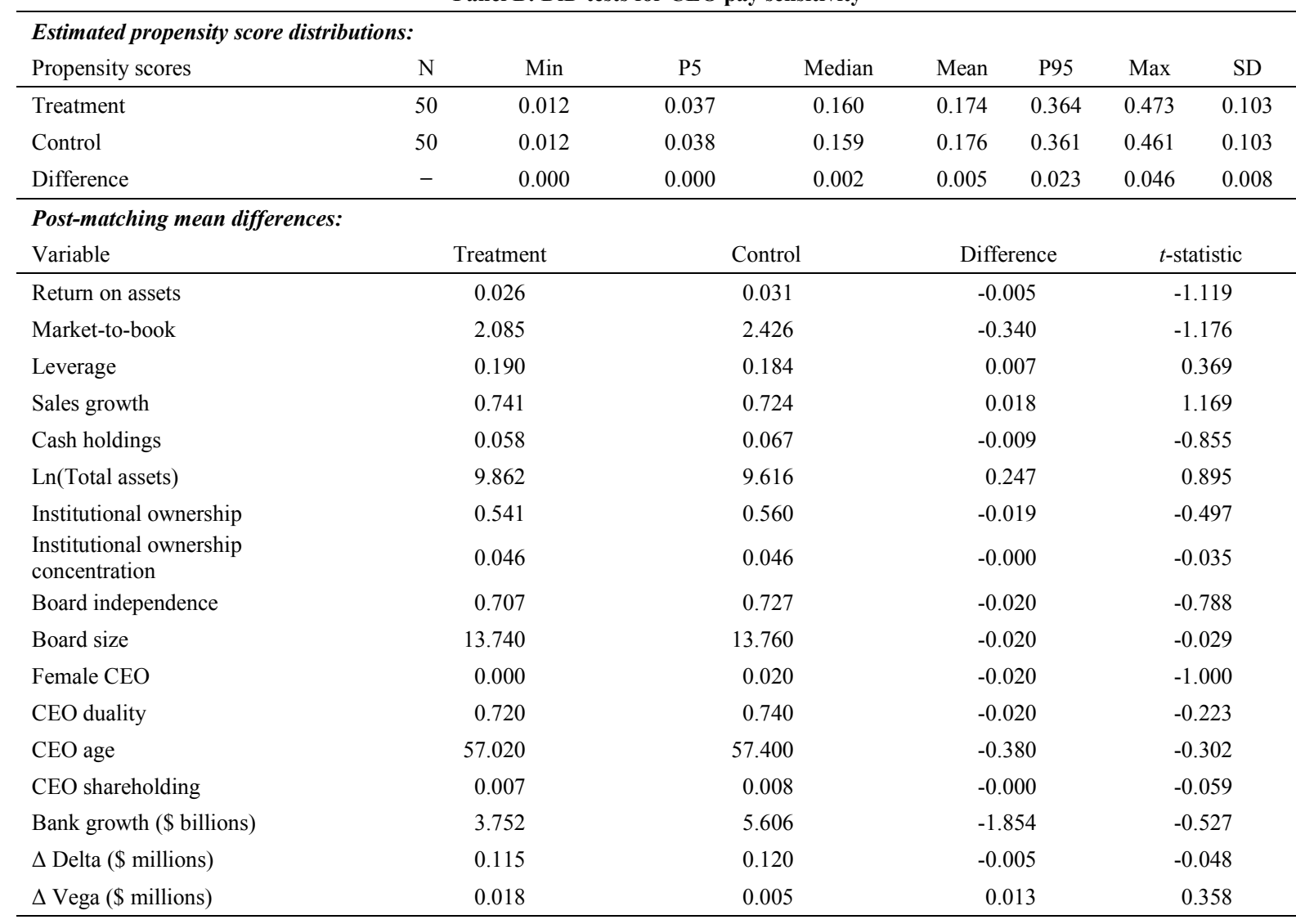

[1]

Mean difference before megamerger (treatment - control)

\begin{tabular}{cc} 
& (treatment \\
\hline Delta & 110 \\
& {$[0.76]$} \\
Vega & 67
\end{tabular}

[2]

Mean difference after megamerger (treatment - control)

$\begin{array}{cc}-88 & -198^{*} \\ {[-0.48]} & {[-1.82]} \\ 42 & -25\end{array}$

[0.99]
[3]

Mean DiD estimator (after-before)

[-0.61]

Notes:

This table presents DiD estimators of the impact of megamerger growth on CEO pay and pay sensitivity. Treatment banks (acquiring banks) and control banks (non-acquiring banks) are matched within the same year, using a one-to-one nearest neighbour propensity score matching with replacement. The DiD estimators are calculated in a five-year event window surrounding the megamerger completion year. The mean difference before (after) megamerger is computed by subtracting the mean of the control group from that of the treatment group over the period before (after) megamerger. The DiD estimator is then computed by subtracting the between-group mean difference before megamerger from that after megamerger. The $t$ statistics based on robust standard errors clustered by firm are given in brackets, testing whether the mean difference is equal to $0 . * * * * *$, and $*$ indicate statistical significance at the $1 \%, 5 \%$, and $10 \%$ levels, respectively. The DiD estimators are reported in thousands of U.S. dollars. See the appendix for variable definitions. 
Table 8

High- versus Low-Megamerger Banks

\begin{tabular}{|c|c|c|c|c|c|c|c|c|c|c|}
\hline & \multicolumn{6}{|c|}{ Panel A: CEO pay } & \multicolumn{4}{|c|}{ Panel B: CEO pay sensitivity } \\
\hline & \multicolumn{2}{|c|}{ Total compensation } & \multicolumn{2}{|c|}{ Equity compensation } & \multicolumn{2}{|c|}{ Cash compensation } & \multicolumn{2}{|c|}{ Delta } & \multicolumn{2}{|c|}{ Vega } \\
\hline & High & Low & High & Low & High & Low & High & Low & High & Low \\
\hline Total assets at $t 3$ & $0.0040 * * *$ & $0.0548 * * *$ & $0.0038 * * *$ & $0.0346 * * *$ & 0.0005 & $0.0093 * * *$ & 0.0004 & 0.0080 & 0.0001 & $0.0022 * * *$ \\
\hline & [3.16] & [4.85] & [5.11] & [3.81] & [0.69] & [4.23] & [0.69] & [1.27] & [0.59] & [2.96] \\
\hline $\begin{array}{l}\text { Assets acquired in megamergers } \\
\text { (\$ millions) }\end{array}$ & $0.1704 * * *$ & $1.9776^{* * *}$ & $0.1582 * *$ & $2.0908^{* * *}$ & 0.0146 & 0.0203 & $-0.0102 * *$ & -0.3440 & -0.0023 & $0.0388^{* * *}$ \\
\hline & [4.03] & [5.28] & [2.57] & [5.86] & {$[0.46]$} & [0.45] & {$[-2.24]$} & {$[-1.58]$} & {$[-0.51]$} & [2.89] \\
\hline $\begin{array}{l}\text { Non-megamerger growth } \\
\text { (\$ millions) }\end{array}$ & $0.0137 * * *$ & 0.0453 & $0.0098^{*}$ & 0.0254 & $0.0026^{* * *}$ & 0.0054 & $0.0026^{* * *}$ & $0.0865^{*}$ & $0.0014 * * *$ & 0.0025 \\
\hline & [2.95] & {$[0.96]$} & {$[1.74]$} & {$[0.74]$} & {$[3.48]$} & {$[0.78]$} & {$[3.55]$} & [1.92] & [5.10] & [1.13] \\
\hline $\begin{array}{l}\text { Change in firm value due to change in industry index } \\
\text { ( } \$ \text { millions) }\end{array}$ & $0.1620^{* * *}$ & $0.0542 * *$ & $0.0816^{* * *}$ & $0.0392 *$ & $0.0569 * * *$ & -0.0073 & $0.0316^{* * *}$ & 0.0119 & $0.0093^{* * *}$ & 0.0003 \\
\hline & [8.38] & [2.33] & [4.55] & [1.76] & [4.69] & {$[-1.25]$} & [10.61] & {$[0.89]$} & {$[3.05]$} & {$[0.17]$} \\
\hline $\begin{array}{l}\text { Change in firm value due to idiosyncratic change } \\
\text { (\$ millions) }\end{array}$ & $0.1052 * * *$ & $0.1513 * * *$ & $0.0517 * *$ & $0.1146^{* *}$ & $0.0400 * * *$ & -0.0038 & $0.0114 * *$ & 0.0278 & 0.0034 & -0.0024 \\
\hline Return on assets $\left(\times 10^{5}\right)$ & $\begin{array}{c}{[4.49]} \\
0.4834^{* * *} \\
{[3.42]}\end{array}$ & $\begin{array}{c}{[2.69]} \\
0.2206 * * * \\
{[2.97]}\end{array}$ & $\begin{array}{c}{[2.13]} \\
0.4937 * * * \\
{[3.23]}\end{array}$ & $\begin{array}{c}{[2.35]} \\
0.1504^{* *} \\
{[2.12]}\end{array}$ & $\begin{array}{c}{[5.41]} \\
0.0085 \\
{[0.28]}\end{array}$ & $\begin{array}{c}{[-0.39]} \\
0.0264 * * * \\
{[2.87]}\end{array}$ & $\begin{array}{c}{[2.07]} \\
0.0696^{*} \\
{[1.85]}\end{array}$ & $\begin{array}{c}{[1.31]} \\
-0.0055 \\
{[-0.28]}\end{array}$ & $\begin{array}{c}{[1.32]} \\
0.0186^{* *} \\
{[2.50]}\end{array}$ & $\begin{array}{c}{[-0.97]} \\
0.0118^{* * *} \\
{[3.95]}\end{array}$ \\
\hline Female CEO $\left(\times 10^{3}\right)$ & $\begin{array}{c}-1.0716^{* * *} \\
{[-3.34]}\end{array}$ & $\begin{array}{r}-0.0548 \\
{[-0.11]}\end{array}$ & $\begin{array}{r}-0.3537 \\
{[-1.18]}\end{array}$ & $\begin{array}{r}-0.2015 \\
{[-0.53]}\end{array}$ & $\begin{array}{l}-0.1821 \\
{[-1.29]}\end{array}$ & $\begin{array}{c}-0.2509^{* *} \\
{[-2.15]}\end{array}$ & $\begin{array}{l}0.0091 \\
{[0.17]}\end{array}$ & $\begin{array}{r}-0.0677 \\
{[-0.43]}\end{array}$ & $\begin{array}{c}-0.0274 * \\
{[-1.95]}\end{array}$ & $\begin{array}{l}0.0014 \\
{[0.04]}\end{array}$ \\
\hline CEO duality $\left(\times 10^{3}\right)$ & $\begin{array}{c}1.7916^{* * * *} \\
{[3.77]}\end{array}$ & $\begin{array}{c}0.6830^{* *} \\
{[2.09]}\end{array}$ & $\begin{array}{c}1.0147^{* * *} \\
{[2.77]}\end{array}$ & $\begin{array}{l}0.3709 \\
{[1.58]}\end{array}$ & $\begin{array}{c}0.3911 * * * \\
{[4.65]}\end{array}$ & $\begin{array}{c}0.1836^{* *} \\
{[2.08]}\end{array}$ & $\begin{array}{c}0.1418^{* *} \\
{[2.23]}\end{array}$ & $\begin{array}{l}0.0674 \\
{[0.58]}\end{array}$ & $\begin{array}{c}0.0740^{* * *} \\
{[2.72]}\end{array}$ & $\begin{array}{c}0.0398^{* *} \\
{[2.36]}\end{array}$ \\
\hline CEO age $\left(\times 10^{3}\right)$ & $\begin{array}{r}-0.0177 \\
{[-0.77]}\end{array}$ & $\begin{array}{c}-0.0092 \\
{[-0.39]}\end{array}$ & $\begin{array}{c}-0.0202 \\
{[-1.23]}\end{array}$ & $\begin{array}{c}-0.0257^{*} \\
{[-1.72]}\end{array}$ & $\begin{array}{l}0.0019 \\
{[0.35]}\end{array}$ & $\begin{array}{l}0.0084 \\
{[1.54]}\end{array}$ & $\begin{array}{l}0.0123 \\
{[1.01]}\end{array}$ & $\begin{array}{l}0.0250 \\
{[1.45]}\end{array}$ & $\begin{array}{l}0.0011 \\
{[0.60]}\end{array}$ & $\begin{array}{r}-0.0003 \\
{[-0.27]}\end{array}$ \\
\hline CEO shareholding $\left(\times 10^{5}\right)$ & $\begin{array}{c}-0.7442 * * * \\
{[-3.62]}\end{array}$ & $\begin{array}{l}0.0212 \\
{[0.40]}\end{array}$ & $\begin{array}{c}-0.4105^{* * *} \\
{[-3.16]}\end{array}$ & $\begin{array}{c}0.0338 \\
{[0.75]}\end{array}$ & $\begin{array}{c}-0.1921^{* * *} \\
{[-3.15]}\end{array}$ & $\begin{array}{l}-0.0015 \\
{[-0.22]}\end{array}$ & $\begin{array}{c}0.2526^{* *} \\
{[2.12]}\end{array}$ & $\begin{array}{c}0.1174 * * * \\
{[3.33]}\end{array}$ & $\begin{array}{c}-0.0328 * * * \\
{[-2.98]}\end{array}$ & $\begin{array}{l}0.0022 \\
{[0.85]}\end{array}$ \\
\hline Adj. $\mathrm{R}^{2}$ & 0.47 & 0.41 & 0.42 & 0.40 & 0.36 & 0.28 & 0.43 & 0.48 & 0.48 & 0.33 \\
\hline $\mathrm{N}$ & 1108 & 645 & 1108 & 645 & 1108 & 645 & 1093 & 627 & 1092 & 626 \\
\hline
\end{tabular}

Notes:

This table reports OLS regression results for high- versus low-megamerger banks. The sample banks are divided into high- and low-megamerger groups by the median dollar value of total megamerger transactions made by banks over the sample period. Intercepts and year dummies are included but suppressed for brevity. The dependent variables are in thousands of U.S. dollars. See the appendix for variable definitions. The $t$-statistics based on robust standard errors clustered by firm are reported in brackets. ***, **, and $*$ indicate statistical significance at the $1 \%, 5 \%$, and $10 \%$ levels, respectively. 
Table 9

Mergers and CEO Compensation in Industrial Firms

\begin{tabular}{|c|c|c|c|c|c|c|c|c|c|c|}
\hline & \multicolumn{6}{|c|}{ Panel A: CEO pay } & \multicolumn{4}{|c|}{ Panel B: CEO pay sensitivity } \\
\hline & {$[1]$} & {$[2]$} & [3] & {$[4]$} & [5] & {$[6]$} & [7] & {$[8]$} & {$[9]$} & {$[10]$} \\
\hline & $\begin{array}{l}\text { Total } \\
\text { compensation }\end{array}$ & $\begin{array}{c}\text { Total } \\
\text { compensation }\end{array}$ & $\begin{array}{l}\text { Equity } \\
\text { compensation }\end{array}$ & $\begin{array}{l}\text { Equity } \\
\text { compensation }\end{array}$ & $\begin{array}{c}\text { Cash } \\
\text { compensation }\end{array}$ & $\begin{array}{c}\text { Cash } \\
\text { compensation }\end{array}$ & Delta & Delta & Vega & Vega \\
\hline \multirow{2}{*}{$\begin{array}{l}\text { Total assets at } t\} \\
\text { (\$ millions) }\end{array}$} & $0.0409^{* * *}$ & $0.0399 * * *$ & $0.0296 * *$ & $0.0224 * *$ & $0.0115^{* * *}$ & $0.0113^{* * *}$ & $0.0065^{* * *}$ & $0.0063 * * *$ & $0.0018^{* *}$ & $0.0018^{* *}$ \\
\hline & [2.74] & {$[2.71]$} & {$[2.24]$} & {$[2.17]$} & {$[5.83]$} & {$[5.85]$} & [2.80] & [2.83] & [2.18] & {$[2.16]$} \\
\hline \multirow{2}{*}{$\begin{array}{l}\text { Assets acquired in } \\
\text { megamergers ( } \$ \text { millions) }\end{array}$} & $0.1297 * * *$ & & $0.1295^{* * *}$ & & $0.0460 * * *$ & & $0.0204 * *$ & & $0.0071 * * *$ & \\
\hline & {$[5.48]$} & & [4.71] & & [4.33] & & [1.99] & & [5.17] & \\
\hline \multirow{2}{*}{$\begin{array}{l}\text { Assets acquired in all } \\
\text { mergers ( } \$ \text { millions) }\end{array}$} & & $0.1512 * * *$ & & $0.1015 * * *$ & & $0.0461 * * *$ & & $0.0284 * *$ & & $0.0088 * * *$ \\
\hline & & {$[5.29]$} & & [4.82] & & {$[4.55]$} & & [2.57] & & [4.96] \\
\hline \multirow{2}{*}{$\begin{array}{l}\text { Non-megamerger growth } \\
\text { (\$ millions) }\end{array}$} & $0.0207^{*}$ & & $0.0226^{*}$ & & 0.0067 & & $0.0130 * * *$ & & $0.0031 * * *$ & \\
\hline & {$[1.76]$} & & [1.96] & & [1.37] & & [2.86] & & [3.66] & \\
\hline \multirow{2}{*}{$\begin{array}{l}\text { Non-merger growth } \\
\text { (\$ millions) }\end{array}$} & & 0.0145 & & 0.0079 & & 0.0061 & & $0.0111 * * *$ & & $0.0027 * * *$ \\
\hline & & {$[1.30]$} & & [1.12] & & {$[1.24]$} & & {$[2.60]$} & & [3.74] \\
\hline \multirow{2}{*}{$\begin{array}{l}\text { Change in firm value due to } \\
\text { change in industry index } \\
\text { (\$ millions) }\end{array}$} & $0.1007 * * *$ & $0.0989 * * *$ & $0.0901 * * *$ & $0.0617 * * *$ & $0.0198 * * *$ & $0.0194 * * *$ & $0.0479 * * *$ & $0.0474 * * *$ & $0.0034 * * *$ & $0.0033 * * *$ \\
\hline & [7.92] & {$[8.06]$} & [7.10] & [7.64] & {$[6.76]$} & [6.67] & [8.87] & {$[8.82]$} & [4.93] & [4.90] \\
\hline \multirow[t]{2}{*}{$\begin{array}{l}\text { Change in firm value due to } \\
\text { idiosyncratic change } \\
\text { (\$ millions) }\end{array}$} & $0.0660^{* * *}$ & $0.0652 * * *$ & $0.0679 * * *$ & $0.0383 * * *$ & $0.0139 * * *$ & $0.0138^{* * * *}$ & $0.0540 * * *$ & $0.0537 * * *$ & $0.0015^{* *}$ & $0.0014 * *$ \\
\hline & [5.79] & {$[5.68]$} & {$[5.15]$} & {$[4.80]$} & {$[4.00]$} & [3.99] & [9.39] & {$[9.24]$} & [2.19] & {$[2.04]$} \\
\hline \multirow{2}{*}{ Return on assets $\left(\times 10^{5}\right)$} & $0.0492 * * *$ & $0.0493 * * *$ & $0.0291 * * *$ & $0.0262 * * *$ & $0.0127 * * *$ & $0.0127 * * *$ & $0.0156^{* * *}$ & $0.0157^{* * *}$ & $0.0024 * * *$ & $0.0024 * * *$ \\
\hline & {$[12.63]$} & {$[12.68]$} & {$[7.96]$} & {$[9.52]$} & {$[12.27]$} & {$[12.26]$} & [8.37] & {$[8.37]$} & [9.91] & {$[9.93]$} \\
\hline Female CEO $\left(\times 10^{3}\right)$ & $\begin{array}{l}0.3222 \\
{[0.95]}\end{array}$ & $\begin{array}{l}0.3202 \\
{[0.95]}\end{array}$ & $\begin{array}{l}0.4953 \\
{[1.46]}\end{array}$ & $\begin{array}{l}0.2917 \\
{[125]}\end{array}$ & $\begin{array}{l}-0.0482 \\
{[-0.74]}\end{array}$ & $\begin{array}{l}-0.0490 \\
{[-0.75]}\end{array}$ & $\begin{array}{l}-0.2022 \\
{[-1.57]}\end{array}$ & $\begin{array}{l}-0.2021 \\
-\end{array}$ & -0.0073 & -0.0073 \\
\hline \multirow[t]{2}{*}{ CEO duality $\left(\times 10^{3}\right)$} & $1.2330^{* * *}$ & $1.2279 * * *$ & $\begin{array}{l}{[1.40]} \\
0.7317^{* * *}\end{array}$ & $\begin{array}{c}{[1.25]} \\
0.6728^{* * *}\end{array}$ & $\begin{array}{l}{[-0.74]} \\
0.2399 * * *\end{array}$ & $0.2392 * * *$ & $0.1465 * * *$ & $\begin{array}{c}{[-1.5 /]} \\
0.1452 * * *\end{array}$ & $\begin{array}{c}{[-0.39]} \\
0.0519 * * *\end{array}$ & $\begin{array}{c}{[-0.40]} \\
0.0516^{* * * *}\end{array}$ \\
\hline & {$[12.29]$} & {$[12.31]$} & [7.91] & {$[9.85]$} & [6.49] & {$[6.48]$} & [3.69] & {$[3.66]$} & {$[9.20]$} & {$[9.23]$} \\
\hline \multirow[t]{2}{*}{ CEO age $\left(\times 10^{3}\right)$} & -0.0097 & -0.0098 & $-0.0316^{* * *}$ & $-0.0264 * * *$ & $0.0148 * * *$ & $0.0148 * * *$ & 0.0010 & 0.0010 & 0.0002 & 0.0002 \\
\hline & {$[-1.35]$} & {$[-1.37]$} & {$[-4.58]$} & {$[-5.56]$} & [3.63] & [3.63] & {$[0.23]$} & {$[0.22]$} & {$[0.49]$} & {$[0.46]$} \\
\hline CEO shareholding $\left(\times 10^{5}\right)$ & $-0.1019^{* * *}$ & $-0.1016^{* * * *}$ & $-0.0688^{* * * *}$ & $-0.0656^{* * * *}$ & $-0.0158 * * *$ & $-0.0158 * * *$ & $0.1256^{* * *}$ & $0.1257 * * *$ & $-0.0028 * * *$ & $-0.0028 * * *$ \\
\hline Adj. $R^{2}$ & 0.26 & $\begin{array}{c}{[-11.14]} \\
0.27\end{array}$ & 0.16 & 0.20 & 0.12 & 0.12 & 0.30 & 0.30 & 0.19 & 0.20 \\
\hline $\mathrm{N}$ & 28838 & 28838 & 28838 & 28838 & 28838 & 28838 & 27930 & 27930 & 27985 & 27985 \\
\hline
\end{tabular}

This table presents OLS regressions of CEO pay and pay sensitivity on merger growth and control variables in U.S. industrial firms. Intercepts, year dummies and industry dummies (Fama-French 48 industry classification) are included in all regressions but suppressed for brevity. The dependent variables are in thousands of U.S. dollars. See the appendix for variable definitions. The $t$ statistics based on robust standard errors clustered by firm are reported in brackets. ***,**, and * indicate statistical significance at the $1 \%, 5 \%$, and $10 \%$ levels, respectively. 
Table 10

Are Banks Different from Industrial Firms (DiD Analysis)

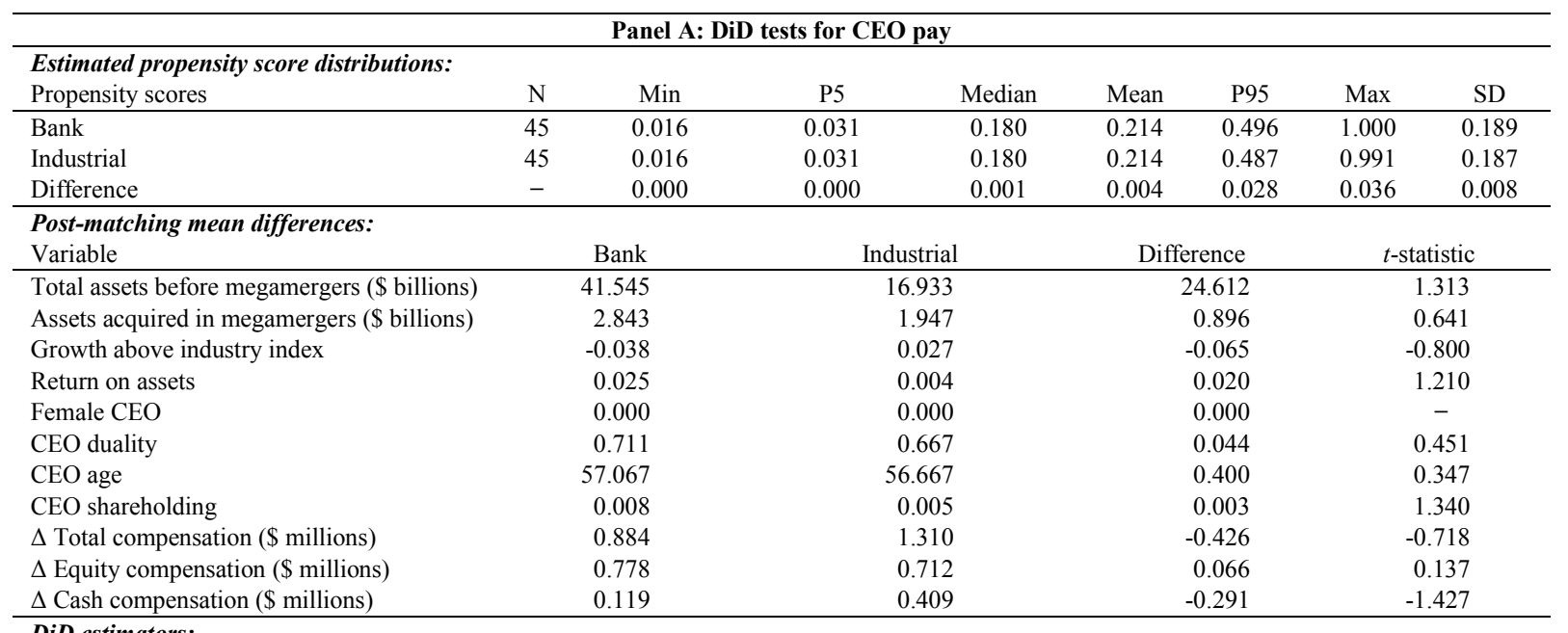

DiD estimators:

[1]

Mean difference before megamerger

[2]

[3]

Mean difference after megamerger Mean DiD estimator (Bank - Industrial) (Bank - Industrial) (after - before)

\begin{tabular}{|c|c|c|c|}
\hline & 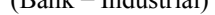 & (ustrai) & pelore) \\
\hline \multirow[t]{2}{*}{ Total compensation } & -729 & 24 & $753 * *$ \\
\hline & {$[-1.11]$} & {$[0.03]$} & {$[2.10]$} \\
\hline \multirow{2}{*}{ Equity compensation } & -421 & -48 & $373^{*}$ \\
\hline & {$[-1.61]$} & {$[-0.15]$} & [1.94] \\
\hline Cash compensation & $\begin{array}{c}-114 \\
{[-0.35]}\end{array}$ & $\begin{array}{c}-7 \\
{[-0.02]}\end{array}$ & $\begin{array}{c}107 \\
{[0.67]}\end{array}$ \\
\hline
\end{tabular}

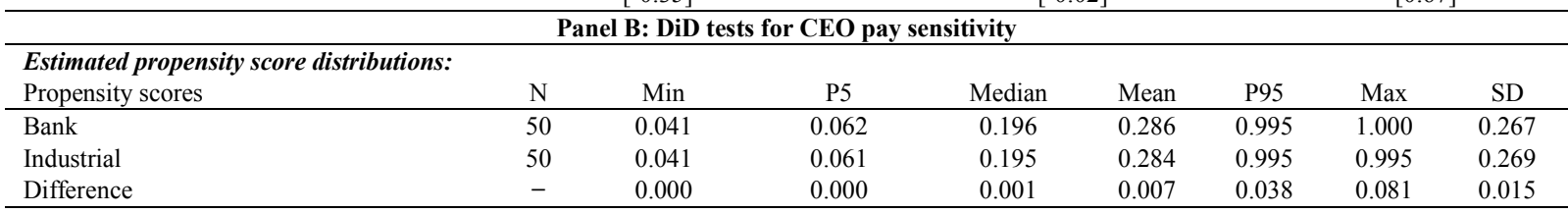

Post-matching mean differences:

Variable

Bank

Industrial

Difference

Total assets before megamergers ( $\$$ billions)

Assets acquired in megamergers (\$ billions)

Growth above industry index

Return on assets

Female CEO

CEO duality

CEO age

CEO shareholding

$\Delta$ Delta (\$ millions)

$\Delta$ Vega (\$ millions)

$\begin{array}{rr}78.273 & 34.789 \\ 3.753 & 2.243 \\ -0.021 & 0.130 \\ 0.023 & 0.010 \\ 0.000 & 0.000 \\ 0.640 & 0.580 \\ 57.520 & 56.960 \\ 0.007 & 0.006 \\ 0.115 & 0.029 \\ 0.018 & 0.042\end{array}$

[1]

[2]

$\begin{array}{rc}t \text { fference } & t \text {-statistic } \\ 43.484 & 1.348 \\ 1.510 & 1.133 \\ -0.150 & -1.617 \\ 0.013 & 1.348 \\ 0.000 & - \\ 0.060 & 0.610 \\ 0.560 & 0.449 \\ 0.001 & 0.469 \\ 0.086 & 0.975 \\ -0.024 & -0.655\end{array}$

DiD estimators:

Mean difference before megamerger (Bank - Industrial)

\begin{tabular}{cc} 
& (Bank - Industrial) \\
\hline Delta & $299^{*}$ \\
& {$[1.76]$} \\
Vega & 68 \\
& {$[0.99]$}
\end{tabular}

Notes:

$[0.99]$

$\begin{array}{rr}.789 & 43.484 \\ .243 & 1.510 \\ 0.130 & -0.150 \\ 0.010 & 0.013 \\ 0.000 & 0.000 \\ 0.580 & 0.060 \\ 6.960 & 0.560 \\ 0.006 & 0.001 \\ 0.029 & 0.086 \\ 0.042 & -0.024\end{array}$

Mean difference after megamerger Mean DiD estimator (Bank - Industrial)

170
$[1.07]$
17
$[0.27]$
(after - before) $-129^{*}$

[-1.92]

$-51$

$[-1.49]$

This table tests whether the merger impact on CEO pay and pay sensitivity differs across banks and industrial firms. Bank megamergers (treatment) and industrial firm megamergers (control) are matched within the same year, using a one-to-one nearest neighbour propensity score matching with replacement. The $\mathrm{DiD}$ estimators are calculated in a five-year event window surrounding the megamerger completion year. The mean difference before (after) megamerger is computed by subtracting the mean of the control group from that of the treatment group over the period before (after) megamerger. The DiD estimator is then computed by subtracting the between-group mean difference before megamerger from that after megamerger. The $t$ statistics based on robust standard errors clustered by firm are given in brackets, testing whether the mean difference is equal to $0 . * * *, * *$, and $*$ indicate statistical significance at the $1 \%, 5 \%$, and $10 \%$ levels, respectively. The DiD estimators are reported in thousands of U.S. dollars. See the appendix for variable definitions. 
Table 11

Global Financial Crisis

\begin{tabular}{|c|c|c|c|c|c|}
\hline \multicolumn{6}{|c|}{ Panel A: Banks } \\
\hline & $\begin{array}{c}\text { Total } \\
\text { compensation } \\
{[1]} \\
\end{array}$ & $\begin{array}{c}\text { Equity } \\
\text { compensation } \\
{[2]}\end{array}$ & $\begin{array}{c}\text { Cash } \\
\text { compensation } \\
{[3]}\end{array}$ & $\begin{array}{c}\text { Delta } \\
{[4]}\end{array}$ & $\begin{array}{l}\text { Vega } \\
{[5]}\end{array}$ \\
\hline \multicolumn{6}{|l|}{ 1992-2007 } \\
\hline \multirow{2}{*}{$\begin{array}{l}\text { Total assets at } t-3 \\
\text { (\$ millions) }\end{array}$} & $0.0212 * * *$ & $0.0104 * * *$ & $0.0081 * * *$ & $0.0017 * * *$ & $0.0015 * * *$ \\
\hline & [6.49] & {$[4.27]$} & {$[8.51]$} & [2.64] & [4.94] \\
\hline \multirow{2}{*}{$\begin{array}{l}\text { Assets acquired in } \\
\text { megamergers } \\
\text { (\$ millions) }\end{array}$} & $0.3640 *$ & $0.2665^{*}$ & $-0.0436 * *$ & $-0.0417 * *$ & -0.0034 \\
\hline & {$[1.90]$} & [1.82] & {$[-2.15]$} & {$[-2.11]$} & {$[-0.81]$} \\
\hline \multirow{2}{*}{$\begin{array}{l}\text { Non-megamerger growth } \\
\text { (\$ millions) }\end{array}$} & 0.0111 & $0.0184 * * *$ & -0.0006 & 0.0033 & -0.0001 \\
\hline & [1.41] & {$[3.16]$} & {$[-0.08]$} & [1.49] & {$[-0.26]$} \\
\hline Controls & Yes & Yes & Yes & Yes & Yes \\
\hline Adj. $\mathrm{R}^{2}$ & 0.53 & 0.42 & 0.52 & 0.33 & 0.60 \\
\hline $\mathrm{N}$ & 996 & 996 & 996 & 989 & 987 \\
\hline \multicolumn{6}{|l|}{2008} \\
\hline \multirow{2}{*}{$\begin{array}{l}\text { Total assets at } t-3 \\
\text { (\$ millions) }\end{array}$} & $0.0209 * *$ & $0.0200 * *$ & 0.0002 & 0.0008 & $-0.0003 *$ \\
\hline & {$[2.35]$} & [2.29] & {$[0.50]$} & {$[1.31]$} & {$[-1.88]$} \\
\hline \multirow{2}{*}{$\begin{array}{l}\text { Assets acquired in } \\
\text { megamergers } \\
\text { (\$ millions) }\end{array}$} & $-0.2857^{*}$ & $-0.2868 *$ & $0.0110 * *$ & $-0.0286^{*}$ & $0.0105 * * *$ \\
\hline & {$[-1.91]$} & {$[-1.89]$} & [2.39] & {$[-1.90]$} & {$[3.25]$} \\
\hline \multirow[t]{2}{*}{$\begin{array}{l}\text { Non-megamerger growth } \\
\text { (\$ millions) }\end{array}$} & -0.0091 & -0.0064 & -0.0005 & 0.0008 & 0.0005 \\
\hline & {$[-0.56]$} & {$[-0.40]$} & {$[-0.76]$} & {$[0.73]$} & [1.43] \\
\hline Controls & Yes & Yes & Yes & Yes & Yes \\
\hline Adj. $R^{2}$ & 0.67 & 0.77 & 0.29 & 0.36 & 0.88 \\
\hline $\mathrm{N}$ & 103 & 103 & 103 & 100 & 100 \\
\hline \multicolumn{6}{|l|}{ 2009-2014 } \\
\hline \multirow{2}{*}{$\begin{array}{l}\text { Total assets at } t-3 \\
\text { (\$ millions) }\end{array}$} & $0.0059 * *$ & $0.0052 * * *$ & 0.0010 & 0.0004 & 0.0002 \\
\hline & {$[2.61]$} & {$[3.16]$} & [1.57] & {$[0.82]$} & [1.11] \\
\hline \multirow{2}{*}{$\begin{array}{l}\text { Assets acquired in } \\
\text { megamergers } \\
\text { ( } \$ \text { millions) }\end{array}$} & $0.8606 * * *$ & $0.6515^{* * *}$ & $0.1489 * * *$ & -0.0235 & $0.0317 * * *$ \\
\hline & [5.24] & [4.15] & [5.72] & {$[-0.72]$} & [2.85] \\
\hline \multirow[t]{2}{*}{$\begin{array}{l}\text { Non-megamerger growth } \\
\text { (\$ millions) }\end{array}$} & -0.0032 & -0.0042 & 0.0001 & $0.0026 * * *$ & $0.0007 * * *$ \\
\hline & {$[-0.85]$} & {$[-1.45]$} & {$[0.11]$} & [3.60] & [3.73] \\
\hline Controls & Yes & Yes & Yes & Yes & Yes \\
\hline Adj. $\mathrm{R}^{2}$ & 0.49 & 0.51 & 0.29 & 0.42 & 0.46 \\
\hline $\mathrm{N}$ & 653 & 653 & 653 & 631 & 631 \\
\hline
\end{tabular}




\begin{tabular}{|c|c|c|c|c|c|}
\hline \multicolumn{6}{|c|}{ Panel B: Matched industrial firms } \\
\hline & $\begin{array}{c}\text { Total } \\
\text { compensation } \\
{[1]}\end{array}$ & $\begin{array}{c}\text { Equity } \\
\text { compensation } \\
{[2]}\end{array}$ & $\begin{array}{c}\text { Cash } \\
\text { compensation } \\
{[3]}\end{array}$ & $\begin{array}{c}\text { Delta } \\
{[4]}\end{array}$ & $\begin{array}{l}\text { Vega } \\
{[5]}\end{array}$ \\
\hline \multicolumn{6}{|l|}{ 1992-2007 } \\
\hline \multirow{2}{*}{$\begin{array}{l}\text { Total assets at } t-3 \\
\text { (\$ millions) }\end{array}$} & $0.0281 * * *$ & $0.0142 * * *$ & $0.0090 * * *$ & $0.0029 * * *$ & $0.0009 * *$ \\
\hline & {$[6.25]$} & {$[4.25]$} & [4.32] & {$[2.84]$} & {$[2.42]$} \\
\hline \multirow{2}{*}{$\begin{array}{l}\text { Assets acquired in } \\
\text { megamergers } \\
\text { (\$ millions) }\end{array}$} & $0.2819 * *$ & $0.2119 * *$ & $0.0724 *$ & $0.0290 *$ & $0.0097 * *$ \\
\hline & {$[2.10]$} & {$[2.02]$} & {$[1.76]$} & [1.87] & {$[2.42]$} \\
\hline \multirow[t]{2}{*}{$\begin{array}{l}\text { Non-megamerger growth } \\
\text { (\$ millions) }\end{array}$} & 0.0211 & 0.0033 & 0.0061 & 0.0068 & 0.0011 \\
\hline & {$[0.90]$} & {$[0.23]$} & {$[0.83]$} & {$[1.21]$} & {$[1.41]$} \\
\hline Controls & Yes & Yes & Yes & Yes & Yes \\
\hline Adj. $R^{2}$ & 0.19 & 0.13 & 0.31 & 0.31 & 0.24 \\
\hline $\mathrm{N}$ & 996 & 996 & 996 & 989 & 987 \\
\hline \multicolumn{6}{|l|}{2008} \\
\hline \multirow{2}{*}{$\begin{array}{l}\text { Total assets at } t-3 \\
\text { (\$ millions) }\end{array}$} & $-0.2515^{*}$ & $-0.1276 * * *$ & -0.1434 & -0.0014 & -0.0020 \\
\hline & {$[-1.71]$} & {$[-2.83]$} & {$[-1.51]$} & {$[-0.10]$} & {$[-0.84]$} \\
\hline \multirow{2}{*}{$\begin{array}{l}\text { Assets acquired in } \\
\text { megamergers } \\
\text { (\$ millions) }\end{array}$} & $1.1899 * *$ & $0.6165 * * *$ & $0.5937 * *$ & -0.0208 & $0.0149 * *$ \\
\hline & {$[2.47]$} & [3.14] & {$[2.26]$} & {$[-0.23]$} & {$[2.41]$} \\
\hline \multirow{2}{*}{$\begin{array}{l}\text { Non-megamerger growth } \\
\text { (\$ millions) }\end{array}$} & 0.8512 & $0.4607 * * *$ & 0.4552 & -0.0135 & 0.0082 \\
\hline & [1.66] & [2.74] & [1.33] & {$[-0.38]$} & {$[1.14]$} \\
\hline Controls & Yes & Yes & Yes & Yes & Yes \\
\hline Adj. $\mathrm{R}^{2}$ & 0.28 & 0.27 & 0.35 & 0.09 & 0.13 \\
\hline $\mathrm{N}$ & 103 & 103 & 103 & 100 & 100 \\
\hline \multicolumn{6}{|l|}{ 2009-2014 } \\
\hline \multirow[t]{2}{*}{$\begin{array}{l}\text { Total assets at } t-3 \\
\text { (\$ millions) }\end{array}$} & $0.0132 * *$ & 0.0029 & $0.0061 * * *$ & 0.0014 & $-0.0004 *$ \\
\hline & [2.37] & {$[0.65]$} & [12.69] & {$[1.53]$} & {$[-1.65]$} \\
\hline \multirow[t]{2}{*}{$\begin{array}{l}\text { Assets acquired in } \\
\text { megamergers } \\
\text { (\$ millions) }\end{array}$} & $0.1888 * *$ & $0.1616^{* * *}$ & 0.0129 & 0.0192 & -0.0044 \\
\hline & {$[2.42]$} & {$[2.70]$} & [0.89] & {$[0.75]$} & {$[-0.73]$} \\
\hline \multirow{2}{*}{$\begin{array}{l}\text { Non-megamerger growth } \\
\text { (\$ millions) }\end{array}$} & 0.0053 & 0.0106 & $-0.0135 * * *$ & 0.0076 & 0.0008 \\
\hline & {$[0.18]$} & {$[0.52]$} & {$[-2.78]$} & {$[1.27]$} & {$[0.30]$} \\
\hline Controls & Yes & Yes & Yes & Yes & Yes \\
\hline Adj. $\mathrm{R}^{2}$ & 0.29 & 0.21 & 0.49 & 0.24 & 0.15 \\
\hline $\mathrm{N}$ & 653 & 653 & 653 & 631 & 631 \\
\hline
\end{tabular}

\section{Notes:}

This table presents OLS regressions of CEO pay and pay sensitivity on megamerger growth and control variables in the precrisis (1992-2007), crisis (2008) and post-crisis (2009-2014) periods. The sample contains banks in Panel A and matched industrial firms in Panel B. Banks and industrial firms are matched using a one-to-one nearest neighbour propensity score matching with replacement. Control variables, year dummies and intercepts are included in all regressions but suppressed for brevity. The dependent variables are in thousands of U.S. dollars. See the appendix for variable definitions. The $t$-statistics based on robust standard errors clustered by firm are reported in brackets. ${ }^{* * *},{ }^{* *}$, and $*$ indicate statistical significance at the $1 \%, 5 \%$, and $10 \%$ levels, respectively. 